\title{
PROPANE DEMAND MODELING FOR RESIDENTIAL SECTORS: A REGRESSION ANALYSIS
}

by

NITIN SHENOY, B.Eng.

\author{
A Thesis \\ $\ln$ \\ INDUSTRIAL ENGINEERING \\ Submitted to the Graduate Faculty \\ of Texas Tech University in \\ Partial Fulfillment of \\ the Requirements for \\ the Degree of \\ MASTER OF SCIENCE \\ IN \\ INDUSTRIAL ENGINEERING \\ Approved \\ Milton L. Smith \\ Chairperson of the Committee \\ James L. Simonton \\ John E. Kobza \\ Peggy Gordon Miller \\ Dean of the Graduate School \\ May, 2011
}


Copyright 2010, Nitin Shenoy 
Texas Tech University, Nitin Shenoy, May 2011

\section{ACKNOWLEDGMENTS}

I would like to express my sincere thanks to my advisor, Dr. Milton L. Smith, for his guidance, encouragement and motivation, throughout the whole process of conducting this research. He has been very helpful and patient in teaching and assisting me since the beginning of this thesis. I am very thankful to have been able to work with him. I would never have believed this research was possible without his assistance. Many thanks also to Dr. John E. Kobza and Dr. James L. Simonton for serving as my committee members.

Finally, I thank my parents and my brother for their inspiration and encouragement during my study abroad. I dedicate this thesis to them. 


\section{TABLE OF CONTENTS}

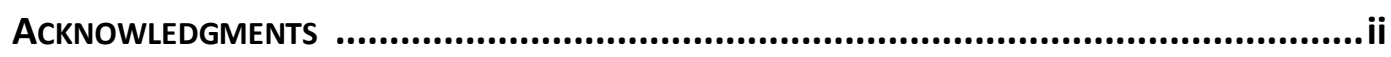

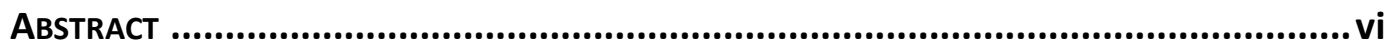

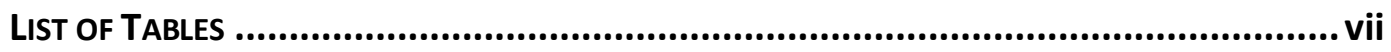

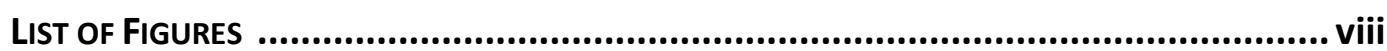

\section{CHAPTER}

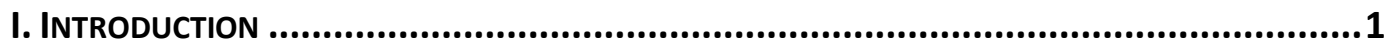

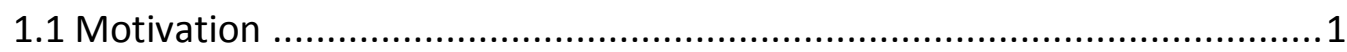

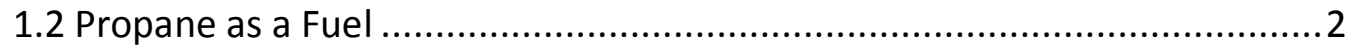

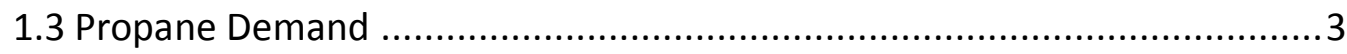

1.3.1 Realistic Residential Propane Usage ................................................

1.3.1.1 Summer Propane Usage ..................................................... 4

1.3.1.2 Winter Propane Usage...................................................... 4

1.4 Factors that Impact Consumption of Propane ……...................................

1.5 Importance of Energy Demand Forecasting .............................................

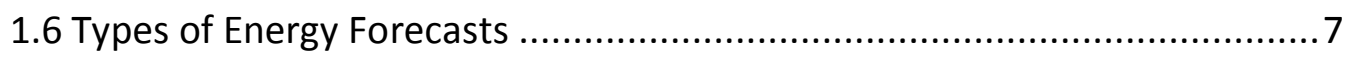

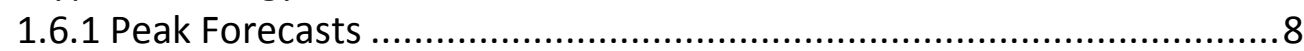

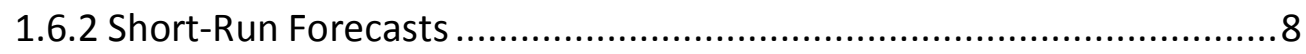

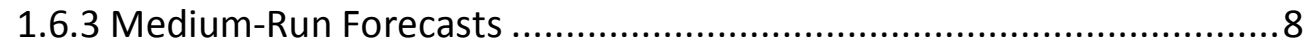

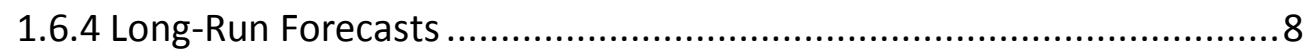

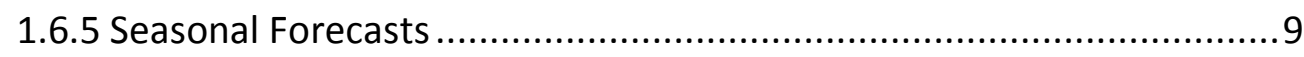

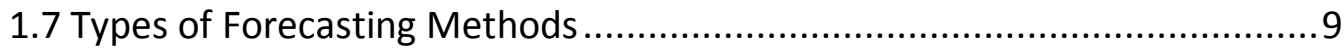

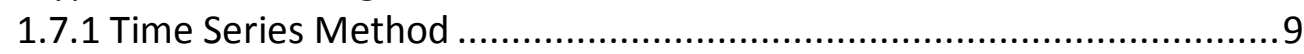

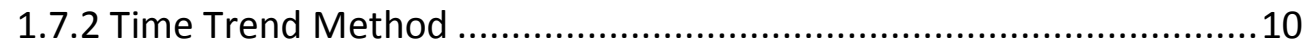

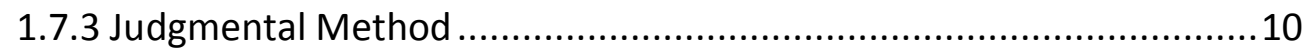

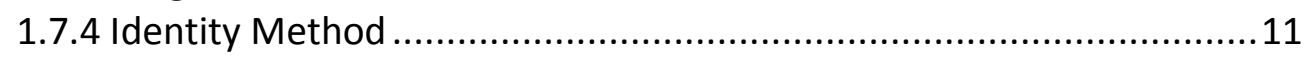

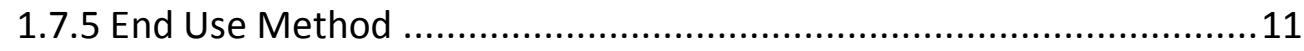

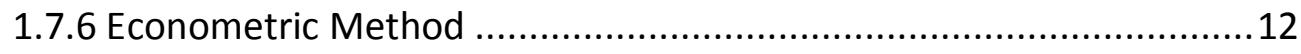


1.8 Problem Statement

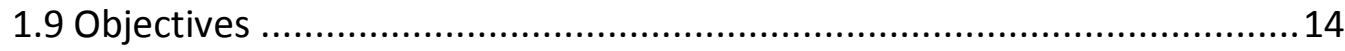

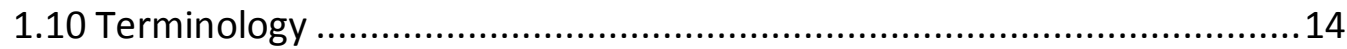

1.10.1 Regular Customers ............................................................... 14

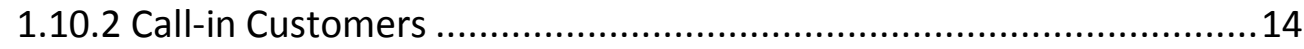

1.10.3 Mobile Homes.................................................................. 15

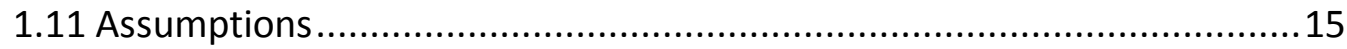

1.12 Expected Results ............................................................ 16

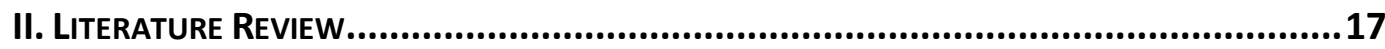

2.1 Supply-Demand Modeling ......................................................... 17

2.2 Electricity Demand Modeling.................................................. 18

2.3 Forecasting Models ..................................................................... 19

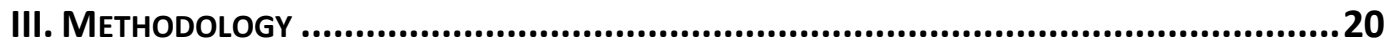

3.1 Model Development.................................................................... 20

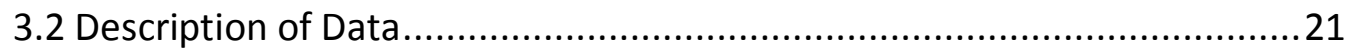

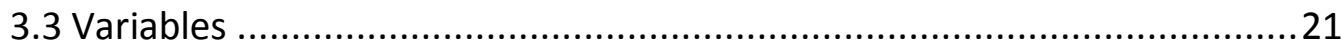

3.3.1 Total Propane Consumed ...........................................................22

3.3.2 Heating Degree Days............................................................ 22

3.3.3 Size of the Houses or Mobile Homes ............................................. 22

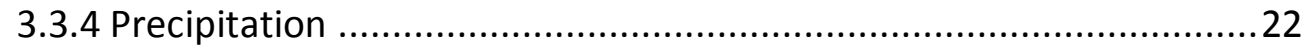

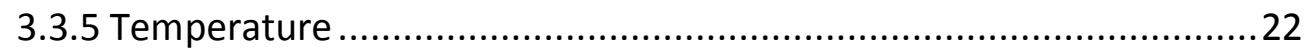

3.3.6 Cooling Degree Days ........................................................... 23

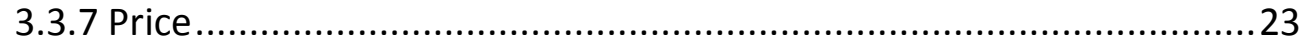

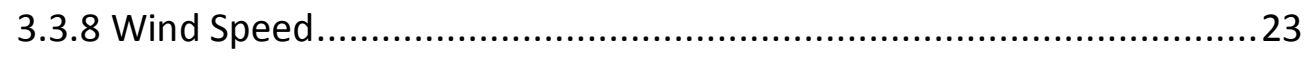

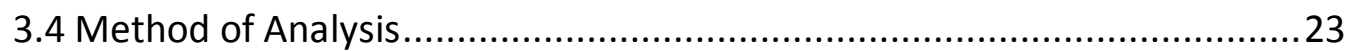

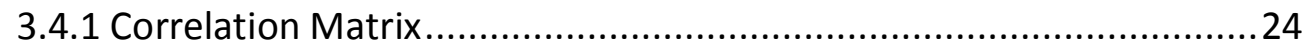

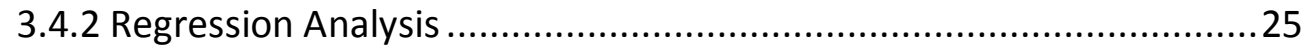

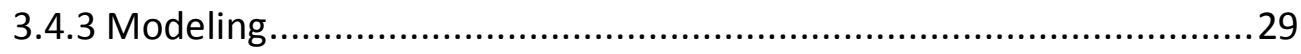


3.4.3.1 Modeling for Houses

3.4.3.2 Modeling for Mobile Homes ...............................................30

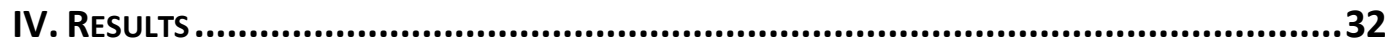

4.1 Regression Analysis Results for Houses..............................................32

4.2 Regression Analysis Results for Mobile Homes ...................................34

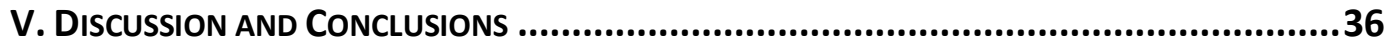

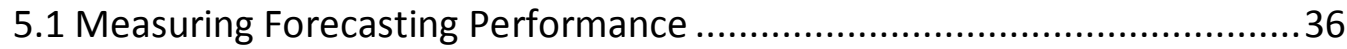

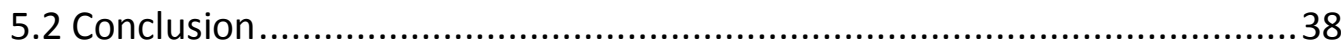

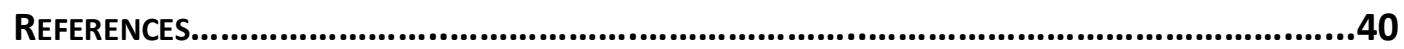

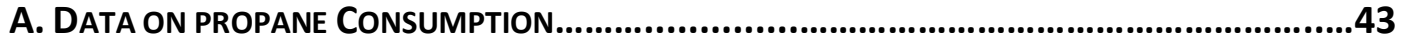

B. SCATTER PLOTS

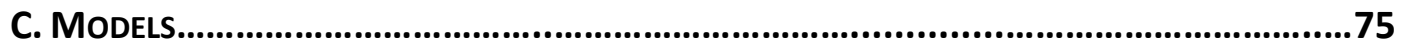

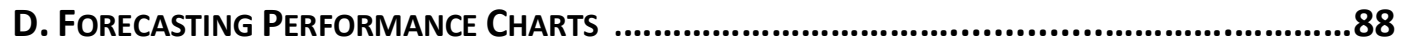




\begin{abstract}
This thesis presents a forecasting model for propane consumption within the residential sector. In this research we explore the dynamic behavior of different variables that affect the propane consumption and develop a forecasting model. The significant factors that had an impact on propane consumption in houses were heating degree days of that area, wind speed, precipitation and the size of the houses. However in the case of mobile homes, only the heating degree days had significance. The behavior of the customers was assumed to be static. This model is based on multiple regression methods. The data was collected from a local propane company in West Texas. Different combinations of months were used in this model to study propane consumption behavior for each month. These different studies were used to generate the final forecasting model. As propane consumption was low for the months from June to September, the best results were obtained when the data for the months from October through May was used for analysis. The results indicate that the forecasting model provides a potentially useful forecast.
\end{abstract}




\section{LIST OF TABLES}

Correlation Matrix of Variables ............................................................ 25

4.1 Demand Forecasting Model for Houses ............................................ 33

4.2 Demand Forecasting Model for Mobile Homes ..................................... 35

F.1 Forecasting Performance Chart......................................................... 38 


\section{LIST OF FIGURES}

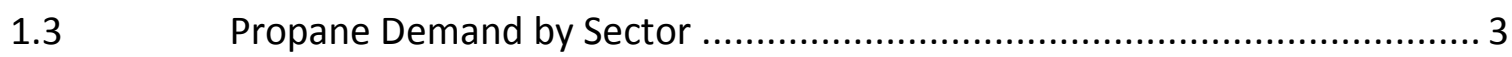

P.4 Propane Demand Graph ...................................................................... 30

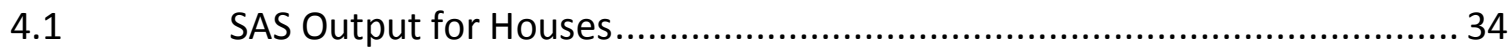

4.2 SAS Output for Mobile Homes ……………........................................ 36 
Texas Tech University, Nitin Shenoy, May 2011

\section{ChAPTER I}

\section{INTRODUCTION}

\subsection{Motivation}

Forecasting is a method of estimation of future outcome of the variables we are interested in. It is an important tool in any business leading to successful managerial decisions. We use forecasts in making strategic decisions under uncertainty. This research is intended to help propane companies do a better job of anticipating, and hence a better job of managing uncertainty, by using effective forecasting and other predictive techniques.

Ideally, large organizations can afford to do forecasting usually by assigning the responsibilities to the people who are best qualified and have the resources at hand to make such estimations under complicated demand patterns. However, small firms do not have enough resources and the staff to carry out these forecasts. Also the smaller firms cannot afford miscalculations in new forecast levels. Hence we decided to forecast the propane demand for a local small firm. Also not many researchers have studied propane demand forecasting. It was this motivation that led us attempt to do the modeling.

This research presents a forecasting model for propane consumption within the residential sector. The forecasting of propane demand may be useful to propane suppliers and customers by providing information on maximum demand to be expected and the duration and timing of these demands. 
Transporting propane is one of the most influential factors that affect propane prices. Propane first moves through underground pipelines to the distribution terminals, from where it is moved to the dealers either by rail or road. These dealers then serve customer demands. Predicting propane demand can help reduce transport costs by not overstocking the storage centers when propane demand is too low.

\subsection{Propane as a Fuel}

Propane is liquefied petroleum gas consumed for different applications in residential, commercial and industrial sectors. In the residential sector, it is primarily used as a space heating fuel. It is also used for water heating, cooking fuel, drying clothes, and sometimes as an alternative fuel for vehicles. Propane is also used as a fuel in many appliances for mobile homes. Portable propane heaters are used as a source of heat for construction and road workers in cold weather.

Propane is largely used to make petrochemicals that are then used for the production of plastics, alcohols, fibers, and cosmetics.

However, propane has not yet become a widely used fuel. Many consumers are not fully aware of the benefits of propane. It is currently the most inexpensive alternative fuel to natural gas. It is a relatively safe fuel to use and also emits fewer toxic chemicals as compared to other alternative fuels. 


\subsection{Propane Demand}

If we look at figure 1.1, about 37 percent of all propane consumed in the United States is used by the petrochemical sector. According to the American Petroleum Institute, about 45 percent is used by the residential and commercial sector.

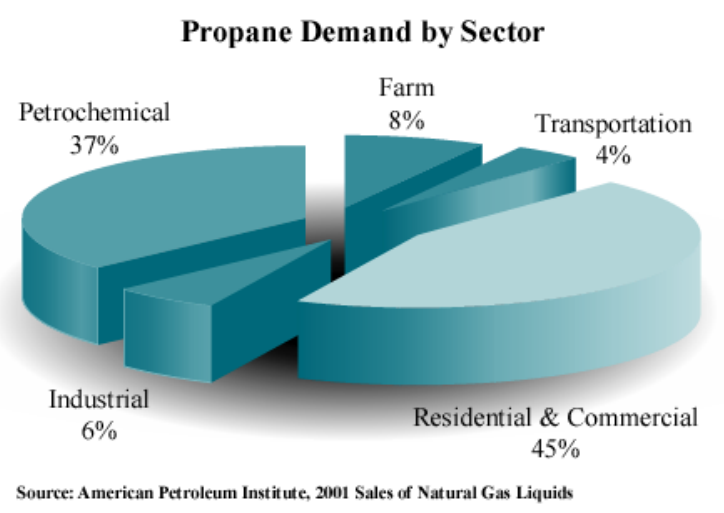

Figure 1.3 Propane Demand by Sector

Of the 107 million households in the U.S., 9.3 million depend on propane for one use or another, and 54 percent of these households rely on propane for their primary heating fuel.

Farmers contribute $8 \%$ of the total propane consumed. They use propane to dry crops. Propane is also used to heat barns, and also used as a fuel to operate farm equipments. 
Propane is most commonly used to provide energy to areas not serviced by a natural gas distribution system. Thus, it competes mainly with heating oil for space heating purposes.

\subsubsection{Realistic Residential Propane Usage}

No one uses their appliances at $100 \%$ all day long and hence we can use a higher than average gas usage approach to find the summer and winter propane usage.

\subsubsection{Summer Propane Usage}

During summers, most of the residential propane is used by cooking appliances, water heaters and dryers. For example, if we consider a water heater (with appliance BTU rating of 220,000 ) used at the rate of $25 \%$ capacity for 2 hours a day, the total propane consumed will be:

$220,000 \mathrm{BTU} / \mathrm{hr} \div 91,547=2.4 \mathrm{gal} / \mathrm{hr}$ (Since one gallon of propane has 91,547 BTU's) Therefore total propane consumed per day will be:

$2.4 \mathrm{gal} / \mathrm{hr} \times 0.25 \times 2 \mathrm{hrs}=1.2$ gallons.

Similarly, we can calculate the propane used by other appliances per day and thus the total propane used by a particular household in summers.

\subsubsection{Winter Propane Usage}

In winters, as the heating requirements increase, more usage of all energy sources is made. Hence, propane used by the household drastically increases. Similar calculations can be used to calculate the propane consumed. 
Since it was not feasible for us to go to each house and calculate the propane consumed, we obtained the data on different households from a local propane distribution center.

Lubbock is located on the Texas South Plains and is at 3200 feet above sea level. It has a population of about 200,000 . The city's propane demand arises primarily from residential units for cooking and space heating purposes in rural areas that are not served by natural gas distribution system.

\subsection{Factors that Impact the Consumption of Propane}

Propane supply and demand is subject to changes in domestic production, weather, and inventory levels, among other factors. Weather conditions have been recognized as being a significant factor in the consumption of propane. While propane production is not seasonal, residential demand is highly seasonal. This imbalance causes the buildup of inventories during the summer months when consumption is low and the drawdown of inventories during the winter months when consumption is much higher. When inventories of propane at the start of the winter heating season are low, chances increase that higher propane prices may occur during the winter season.

Colder-than-normal weather can put extra pressure on propane prices during the high demand winter season because there are no readily available sources of increased supply except for imports. Imports may take several weeks to arrive, during which time above normal withdrawals from inventories may occur, sending prices 
upward. Cold weather early in the heating season can cause higher prices to occur earlier, since early inventory withdrawals affect supply availability of the propane.

\subsection{Importance of Energy Demand Forecasting}

As the future is uncertain energy demand forecasting is very important.

Energy demand forecasting is nothing but to predict what will be the demand in future for a particular source of energy. For examples, forecasting propane demand helps to determine if there will be a shortage of propane in the storage or distribution center, and is there a need for new distribution station or a storage facility, or vice-versa that there is an overabundance of propane i.e. far more than the demand and if there is a need to shut down few facilities.

Cost is another reason for developing the energy demand model. Too low forecasts will result in a shortage of energy, which will lead to increase in the prices and as a result the consumers will have to pay more for the service. High forecasts will result in over abundant supply which might result in shutting down of few storage or distribution centers. The costs associated with this shutting down will be passed on to the consumers. Hence forecasting energy plays an important role in determining costs and thus might have an effect on the consumer behavior.

There should always be a timely and reliable availability of energy supplies and this is directly related to the economy. Also the investments in such energy systems are very high and can largely affect the economy of a country. Hence forecasting energy demand is very important for any country. 
In any energy service market, the market will always decide price and price will determine demand. Therefore the importance of energy demand forecasting grows.

\subsection{Types of Energy Forecasts}

Many types of energy demand forecasting techniques exist. The energy consumption pattern varies over time. It also varies according to season.

More consumption of energy is used during the winter and summer months than in spring and fall. Because the temperatures during summers and winters are extreme while moderate during fall and spring.

Also energy consumption varies within a day. During day time less energy is used as people tend to go to work or are usually not present in their respective houses. The energy consumption increases during night till early morning. It also varies from day to day. During weekdays less amount of energy is used as compared to weekends when people stay at home. During evenings and weekend people tend to watch television, or play games, they cook food and also need light to see. As a result more energy is consumed.

As a result there are different types of forecasts, namely:

1) Seasonal forecast

2) Short run forecast

3) Long run forecast

4) Peak Demand forecast 
5) Medium run forecast

These different types of forecasts are used to determine the energy level at different levels.

\subsubsection{Peak Forecasts}

During summers and winters there are some days when maximum amount of energy is required. Forecasting such days is called peak demand forecasting technique.

In winters sometimes temperature in North America goes bitterly cold. As a result there is more demand for energy to heat the space. Similarly, temperature during summers goes very high which demands for more air conditioning. Hence peak demand forecasting is necessary to ensure that there is enough energy to heat or cool a place.

\subsubsection{Short-Run Forecasts}

Shorts run forecasts are forecasting for a very small period of time. They are valid for a few hours in future. These forecasts are important for the energy service unit who have to schedule and dispatch units on time within a given day.

\subsubsection{Medium-Run Forecasts}

Medium run forecasts are valid from 3 months to several months.

\subsubsection{Long-Run Forecasts}

A long run forecasts are valid from five to twenty-five years into the future. 


\subsubsection{Seasonal Forecasts}

Seasonal forecasts are valid for a particular season. They are used to predict the peak demand for a forthcoming season.

\subsection{Types of Forecasting Methods}

Different methods are used for forecasting energy demand. Those include time-series method, time-trend method, judgmental method, identity method, end use method and econometric method. Detailed explanation of these methods is given below.

\subsubsection{Time-Series Method}

The time-series method is used for data with a pattern or trend over time. It consists of either one variable i.e. univariate or many variables i.e. multivariate. Such forecasts are usually based upon historical data for the loads being forecast. Timeseries is mainly used to project seasonal patterns and daily or seasonal loads.

Time-series methods are often accurate for short term and also less expensive compared to other methods. Only a small data set can be used to carry out this method.

However there are a few disadvantages of this method. Many a times, historical data patterns cannot be applied to long term forecasts. Also the error sources are difficult to interpret. 


\subsubsection{Time-Trend Method}

Time-trend methods are considered when data follows a permanent deterministic pattern across time. It determines the overall trend in historical data and develops the forecast based upon that trend. Earlier this method consisted of plotting the data on graph paper and laying a ruler through the points. Time-trend method can be used for short-term modeling. This method is vulnerable to many errors.

The main advantage of this method is that it requires little skill and is inexpensive. It can be modeled as per requirements by changing data. The data set required for such analysis is very small.

The main disadvantage of this method is that it is vulnerable to many errors. It does not pay attention to any influences.

\subsubsection{Judgmental Method}

The judgmental method uses information obtained from experts in the field rather than numerical data. This relies on judgments, opinions and probabilistic estimates from experts. The knowledge of experts like managers, developers, etc. is used to develop the forecast. When other forecasting methods do not work, it is better to rely on judgmental method. It is sometimes the most effective of all methods.

Judgmental methods are usually low cost. It uses the expertise and knowledge available freely. It is helpful when there is no historical data available. 
However, there are a few disadvantages for this method. The expert opinion can be wrong sometimes. Also experts are no always available for their opinion. This method is not accurate enough as it does not make use of any statistical techniques.

\subsubsection{Identity Method}

The identity method uses separate forecasts of two variables and then defines a relationship between them. It is a very basic form of forecasting energy demand. The data required for this method are always generated by other forecasting models. This model is usually used for forecasting electricity in a particular area of service. Underlying factors are not accountable in this method and so this method can sometimes be very uncertain.

It is a very simple method as no special skills are required and the forecast can be computed in a very short period of time. It is a much accurate method for forecast as it uses other independent forecasts.

However, it is a very difficult method and it sometimes can subject to great uncertainty.

\subsubsection{End Use Method}

The end-use method is generally used to forecast electricity demand for a particular house. It forecasts using the data from all of the electrical appliances used in the home. It sums up all the end-use activities. End-use models must include all the energy consumed data by type of equipment or process. This method is usually applied to residential sectors. 
The main advantage of this method is that it gives a detailed understanding of how equipment is used and how it changes over time. Errors in forecasting can be easily interpreted. The computer skills required for this method is intermediate. It can be used as a great tool for marketing. This method is easy to understand and explain it to others.

Data on end use may not be available all the time. This method takes a lot of time and also requires large amount of detailed data. It is a very difficult and a costlier method. Sometimes long term forecasts using this method can be tedious.

\subsubsection{Econometric Method}

The econometric method is the most complex technique used for forecasting energy demand. It considers the influence of independent variables on the demand variable. Econometric models usually use time-series data and usually include regression analysis. They can be used for all sectors namely residential, industrial, and commercial. A lot of data is required for forecasting using this method. It requires the data such as incomes, prices of the variables required to forecast, weather factors if applicable, etc.

Econometric methods provide a statistical interpretation of forecasting uncertainty. It measures the underlying causes of different trends. It is one of the most accurate methods of forecasting and it is very easy to re-estimate such models. The data required for developing such models can be easily available. 
The disadvantages of econometric models are that it is very expensive and also the data required to carry out the analysis is large. The skill and experience required in computer programs is too high.

\subsection{Problem Statement}

Because the propane demand is seasonal there is a huge imbalance between inventories in the summer and winter months. Demand for propane is low in the summer months and as inventories build up and the prices go downward. As demand begins to increase in winters and the temperature drops prices go high. Household consumption of propane depends highly on weather conditions and hence is a major reason of increased demand in the winter.

The inventories that build up during the summer are used as a cushion during the winter months, but soon the demand starts to overtake supply. However sometimes there can be a shock demand when the winter or cold weather falls quite before expected. This can lead to an imbalance in the supply and demand of propane. So the problem of this research was to forecast propane demand so as to obtain a balance between the supply and demand during the winter months and thus not hike the propane prices.

Another problem was to estimate the number of in-call customers. Some propane supply companies have two types of customers; those served on regular (usually monthly) schedule and those who call in for service only when propane is needed. This second type of customers present the most difficult type to serve since 
their need for delivery is unscheduled and often urgent. A predictive model such as one presented in this research can be used by a propane supply company to have a better estimation of the number of call in demands for service.

\subsection{Objectives}

The objective of this thesis is to develop a winter residential propane energy demand model for West Texas Gas, Inc. service area in Lubbock. Regression analysis was used to test the model. Therefore, the objectives of the thesis are:

1) Develop a winter residential propane energy demand model for West Texas Gas, Inc. service area in Lubbock

2) Use regression analysis to analyze the model.

3) And measure the forecasting performance by calculating a percentage of error between the actual and derived values.

\subsection{Terminology}

\subsubsection{Regular Customers}

Regular propane customers are those that are long term customers with the propane company. They are reliable in paying for propane service and also require propane on a monthly basis. These customers pay for the bill later as they are billed for service by on a monthly basis.

\subsubsection{Call-in Customers}

Call-in customers are customers who call for service when they are low on propane. They also may not have enough money to pay for the bill every month. 
Some call-in customers call only when they have the cash to pay upon delivery.

Usually these call-in customers move frequently, hence the demand fluctuates and also the propane company has a risk a customer moving away with an unpaid bill.

\subsubsection{Mobile Homes}

Mobile homes are first built in factories and then taken to the site where it has to be installed. These homes are usually fixed at one location permanently and cannot be moved.

\subsection{Assumptions}

1) The customer behavior is assumed to be static. That is, the regular customer does not change their demand every year depending on the prices or other factors.

2) The propane price is not considered to be a significant factor in determining or predicting the propane consumption.

3) This research has been limited to forecasting for normal periods that is periods without irregularities in demand caused by holidays or festivals.

4) Data is obtained from West Texas Gas Inc. and the parameters are calculated as per their records.

5) Only data for $20-30$ houses was collected and the rest of the houses were assumed to have the same demand.

6) The economic effect on the propane consumption is considered to be constant. 
Texas Tech University, Nitin Shenoy, May 2011

\subsection{Expected Results}

Different solutions for houses and mobile homes were developed. The models

provided potentially useful forecasts. Evaluations of the solutions were also been made. 
Texas Tech University, Nitin Shenoy, May 2011

\section{ChAPTER II}

\section{LITERATURE REVIEW}

There are not many researches who have attempted to predict the propane demand as it is not a widely used fuel. However, similar predictions on the demand from other sources of energy have been made. The need for accurate energy forecasts began during the industrial revolution when there was a need for the efficient use of energy (Burns, 1984).

\subsection{Supply-Demand Modeling}

In 1987, a model for energy supply and demand in the state of Illinois was introduced. In developing countries, the major part of energy is consumed by households. In 1990, Kamal Rijal used a linear multiple regression demand forecasting model for presenting the energy requirements in Nepal [17]. A few years later, in 1993 an energy demand-supply model for developing countries was suggested by Vishwa B. Amatya [5]. His model was based on the demand for wood resources in Nepal. There model was capable of simulating different cases or scenarios. It was based on an end-use/process analysis approach. Also in the same year, Fang Zhen carried out a research to forecast energy supply-demand [26]. He developed, an optimized linear model for energy demand-supply forecasting for a village in north China. In 1997, a model called LEAP model (Long-range Energy Alternative Planning) was developed by Bala [8]. He developed a dynamic model of supply and demand forecasting for rural energies and also impacts it had on the 
environment. The output of this model was employed in another similar model associated with energy and environmental concerns.

\subsection{Electricity Demand Modeling}

In 1966, researchers G. T. Heinemann and D. A. Nordman published a paper on relationship between summer weather and summer loads [13]. This demand modeling was done using regression techniques. Regression analysis showed that the combined effect of the weather variables can be expressed by one composite weather variable.

Houthakker and Taylor in 1970 developed a dynamic model for forecasting energy demand [14]. Their model determined the current level of the variable by the cumulative effects of past behavior. Later this approach was used to model predict the residential electricity demand and also the price at national and state level. In 2005, Bernstein and Griffin did an analysis to estimate the prices at national and regional levels [10]. They found out that there was a huge difference between the prices at various regional levels. Also there was a huge difference between national and regional levels.

In 1997, Baltagi and Griffin and suggested that homogeneous estimators were better at predicting demand [9]. This shows that a lot of research was carried out from the year 1966 till today on electricity demand and prices. 
Texas Tech University, Nitin Shenoy, May 2011

\subsection{Forecasting Models}

A modern technique of forecasting energy demand was developed by AlGarni, Zubair, and Nizami in 1994 [6]. They developed this model for Saudi Arabia. They used statistical method for forecasting. The summers in Saudi Arabia are very hot as so they decided to forecast the energy during warm weathers.

Similar research was done by Leung and Miklius in 1994 on Hawaii [16]. They used different statistical methods of energy forecasting. Again Hawaii's warm climate may lead to excessive demand and so forecasting was necessary.

Many other researchers developed forecasting methods using statistical methods. Summer residential energy demand forecasting model was developed by S. V. Lee in the year 1983 [15]. He studied which factors influenced summer peak residential energy demand and then forecasted demand based on those factors. His model is very similar to our models.

Halvorsen suggested that residential electricity demand is a function of both economic and non-economic variables [12]. All these factors can be included while developing a forecasting model. 
Texas Tech University, Nitin Shenoy, May 2011

\section{ChAPTER III}

\section{Methodology}

Forecasting is to make statements about the events in future by using the variables from present and past. Although there is no way through which we can predict the future completely, but forecasting helps to make the necessary changes required now in order for avoiding uncertainties and risks in the future. This section describes the methodology used to forecast the residential propane demand.

\subsection{Model Development}

Residential propane demand is affected by many different factors. Initially, we observed that the residential propane demand is a function of propane price, size of the houses and mobile homes, economy, number of customers and weather variables.

Cold waves during winters can cause many problems when the temperature reaches very low levels. As the temperature decreases, the demand for propane increases due to increased demand for heating devices. A temperature variable like heating degree days measures the relationship between temperature and demand.

Size of the houses can also be very important factor in determining the demand for each house. The amount of propane consumed has a relationship with the size of the houses. Larger houses require more propane because the heating space is more. 
Precipitation is another factor that has a relation with propane consumption. Precipitation can lead to cold weather, heavy snowfall and rainfall. This will bring the temperature down and as a result the need for propane to heat the space will increase.

Propane price is another factor that influences its consumption. As price goes up, the consumer tends to use less propane and when the prices are low they use more. Also, if the consumers have a cheaper option, they will always go for the inexpensive one. However, in a small town like Lubbock the price of propane did not affect much on the consumer's behavior. Hence, the data on the price of propane was rejected.

\subsection{Description of Data}

All the data on monthly propane consumed by different houses from the year 2004 through year 2009 was obtained from a company that serves Lubbock. Data on weather variables was obtained from the U.S. records on historical weather data. The data is shown in Appendix $A$ in the tables 2-5.

The data obtained was at county level. County level was selected because the company West Texas Gas, Inc. mainly serves the county of Lubbock in West Texas.

\subsection{Variables}

The variables represent the factors that influence the propane consumption. Various variables were considered at the beginning. However, the model obtained was influenced only by a few of these factors. 


\subsubsection{Total Propane Consumed}

The total propane consumed is the total energy demand consumed by the customers served by West Texas Gas, Inc.

\subsubsection{Heating Degree Days}

Demand for energy to heat is home is often calculated using the heating degree days. They are defined with respect to a base temperature above which the system needs no heating. Usually the base temperature is considered as $65^{\circ} \mathrm{F}$. One problem using heating degree days is that they do not consider all weather factors, like humidity, wind, etc. The data on heating degree days was obtained from U.S. records for weather.

\subsubsection{Size of the Houses or Mobile Homes}

Size of the houses or mobile homes is measured in square foot. One problem using the size of the house was that it did not consider the height of the room. Hence the heating space was considered as square foot and not cubic foot.

\subsubsection{Precipitation}

Precipitation is the condensation of water vapor that takes place in the atmosphere and falls under gravity.

\subsubsection{Temperature}

Temperature is a quantity that is used to measure the amount of hotness or coldness. Low temperatures are referred to as coldness and high temperatures as hotness. 


\subsubsection{Cooling Degree Days}

Cooling degree day is a similar quantity to heating degree day, the difference being that it is the amount of energy required to cool a space.

\subsubsection{Price}

The price of the propane is a variable which might have an effect on the consumer behavior.

\subsubsection{Wind Speed}

Wind speed is the velocity at which wind travels. Sometimes during colder weather high wind speed can get lower wind chills which make us feel colder than what the actual measured temperature is.

\subsection{Method of Analysis}

At early stages of the research, it was decided to use only the readily available weather variables to forecast the propane demand. The U.S. maintains a record of historical data on weather which includes temperature, heating degree days, cooling degree days, wind speed, precipitation, snowfall and relative humidity. The data on size of the houses and the average monthly propane consumption was obtained from a local propane company that serves about $50 \%$ of the customer demand in Lubbock. It was necessary to examine the history of each variable affecting the propane consumption in order to establish trends.

Firstly, the software Minitab was used for developing scatter plots which helped to find the correlation between various factors. Later, regression analysis was 
used to find a relationship between the total propane consumed and the correlated independent variables. SAS 9.1 was used as a tool to run the regression analysis.

\subsubsection{Correlation Matrix}

Scatter plots were produced to find the correlation between different variables. Scatter plot gives an idea of how does a dependent variable change with respect to the independent variables. A best fit line is always drawn in the plot to study the correlation. The scatter plots for different variables are shown in Appendix B.

Using excel toolbar a correlation matrix was also developed for all the variables that might have an influence on the propane demand. The variables considered were:

1) Propane Demand

2) Heating Degree Days

3) Temperature

4) Precipitation

5) Cooling Degree Days

6) Price

7) Wind Speed

Shown below is the correlation matrix for all the variables. 
Table 3.4 Correlation Matrix of Variables

\begin{tabular}{|c|c|c|c|c|c|c|c|}
\hline Matrix & Demand & $\begin{array}{l}\text { Heating } \\
\text { Degree } \\
\text { Days }\end{array}$ & $\begin{array}{l}\text { Tempera } \\
\text { ture }\end{array}$ & Precipitation & $\begin{array}{l}\text { Cooling } \\
\text { Degree } \\
\text { Days }\end{array}$ & Price & $\begin{array}{l}\text { Wind } \\
\text { Speed }\end{array}$ \\
\hline Demand & 1 & & & & & & \\
\hline $\begin{array}{l}\text { Heating } \\
\text { Degree Days }\end{array}$ & 0.875 & 1 & & & & & \\
\hline Temperature & -0.889 & -0.991 & 1 & & & & \\
\hline Precipitation & -0.436 & -0.487 & 0.509 & 1 & & & \\
\hline $\begin{array}{l}\text { Cooling Degree } \\
\text { Days }\end{array}$ & -0.668 & -0.718 & 0.787 & -106 & 1 & & \\
\hline Price & -0.269 & -0.122 & 0.141 & 0.216 & 0.174 & 1 & \\
\hline Wind Speed & 0.023 & -0.217 & 0.211 & -0.152 & 0.161 & 0.2 & 1 \\
\hline
\end{tabular}

As seen from the above table the variables price and wind speed hardly have an effect on other variables. Hence the data on these was rejected from the model. Also you can see that the heating degree day had a positive correlation with the demand for propane. Temperature had a negative correlation with the demand.

\subsubsection{Regression Analysis}

Regression analysis is a technique used for modeling and analysis. It is used when we have to find a relationship between the dependent and independent 
variables. It estimates the value of dependent variable given the independent variables.

Multiple linear regression analysis was used for the modeling. The regression equation was as follows:

$X=A_{0}+A_{1} Y_{1}+\ldots \ldots \ldots \ldots \ldots+\ldots . . . . . . . . A_{n} Y_{n}$

where; $\mathrm{X}=$ Average monthly consumption of propane (Demand)

$Y_{i}=$ Independent variable

$A_{i}=$ Coefficient of regression

The regression coefficient measures the amount of change that will occur in the dependent variable for every unit change in the independent variables.

Definitions of some regression statistics is given below.

1) Population

Samples are always obtained for a population. As the size of population is too large, hence samples are always taken from the population for analysis.

2) Mean

Mean is the average of the samples taken from the population. The mean is represented by the following equation:

$X=\left(X_{1}+X_{2}+X_{3}+X_{4}+X_{5}+\ldots \ldots \ldots\right) / n$, where $n$ is the number of observations. 


\section{3) Regression Coefficients}

A constant coefficient is always considered as a base level for prediction. The rest of the coefficient defines the effect of the independent variables on the dependent variable. These coefficients are multiplied with the independent variables for predictions.

4) Least squares

Least squares are an estimation method used in regression analysis. It minimizes the sum of squared deviations.

5) Residuals

Residuals are the difference between estimated values and actual values for a given dependent variable.

6) Standard Errors

Standard errors gives an idea about how reliable are the regression coefficients. It determines the strength of the residuals.

7) Sample Variance

Sample variance tells us how far the set of values are from each other within a given sample. It is usually calculated with respect to the mean of the sample.

8) Standard Deviation

The square root of variance is called standard deviation. 
9) Degree of Freedom

Degree of freedom is the number of observations minus the number of coefficients estimated. The prediction largely depends on the degree of freedom. Lower values of the degree of freedom will give us a poor estimate. Hence an estimate should always have a higher degree of freedom.

10) $R^{2}$

It gives us a degree of success in predicting the values of dependent variable. It ranges from 0-1 scale. More the value closer to 1 will suggest that the predicted values are highly reliable. If the value is closer to 0 then it suggests that the regression fit is worse and we need to make changes in our model.

11) Adjusted $R^{2}$

When $\mathrm{R}^{2}$ is adjusted for the degrees of freedom it is called adjusted $\mathrm{R}^{2}$. Addition of new variables result in the loss of a degree of freedom and thus adjusted $R^{2}$ can suggest if the model has improved or gone worse than the previous one. If there is more than one variable then adjusted $R^{2}$ is always less than the value of $R^{2}$.

\section{2) F-Statistic}

It determines whether the overall fit of the equation developed is significant or not. It can also be defined as a measure of correlation between the dependent and the independent variables. 


\subsubsection{Modeling}

Demand forecasting models were developed separately for houses and mobile homes.

\subsubsection{Modeling for Houses}

The initial step before applying the regression model was to identify those variables that are associated with the changes in dependent variable. A large set of variables were identified as possibly having an impact on the dependent variable, but only a few of them actually had an impact.

Scatter plots were used to identify variables having an impact on the dependent variable with a reasonable level of confidence.

The weather variables precipitation $(P)$, heating degree days (HDD) or temperature $(T)$ and wind speed $(S)$ showed a linear relationship with the dependent variable (Propane Demand) and hence these variables were used in the regression equation. However we chose to use HDD instead of temperature as heating requirements of a house were directly proportional to the number of HDD of that area. The absence of relative humidity in our equation is because of low relative humidity that prevails in Lubbock, thus having a low impact on the demand for propane.

Initially only one model was developed for all size of houses. Later we found that the model was differing greatly in terms of size. Hence, two models were generated for different size of the houses. Small houses being 2000 square feet \& 
below and those above 2000 square feet were considered large houses. This produced more significant forecasts. Histograms of monthly propane demand were established from December 2004 through December 2008. Figure 3.4 presents one of these histograms for a specific residence.

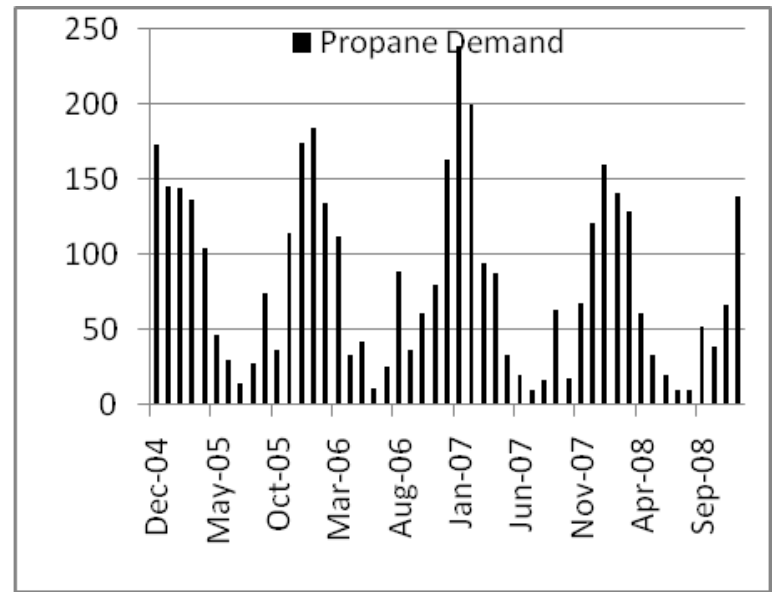

Figure 3.4 Propane Demand Graph

It is necessary to alter the data to account for the fact that all the variables vary throughout the year. Many similarities in the demand pattern were observed for the months from October through May. Demands for the months from June till September did not resemble the demands for the other months. Therefore, we decided to exclude the demands for the summer months from the data sets. We also assume that there is no significant effect of the price of propane upon consumer's use habit.

\subsubsection{Modeling for Mobile Homes}

The procedure to model propane demand in mobile homes was similar to that of the houses. Scatter plots were developed for different variables that were 
Texas Tech University, Nitin Shenoy, May 2011

considered to have an impact on the demand, but the graph results indicated that only HDD had significant impact. The graphs unlike those for the houses did not show the variables precipitation and the size having any effect on the propane consumed. Also histograms suggested that the propane demand was too low for the months from June till September and hence we had to reject those data. 


\section{Chapter IV}

\section{RESULTS}

Regression analysis was carried out separately for houses and mobile homes.

The propane demand for house largely depended on the size

\subsection{Regression Analysis Results for Houses}

The stepwise regression procedure from the SAS software was used to perform the regression analysis. The independent variables used for the analysis of houses are as follows:

1) Heating Degree Days

2) Size of the houses as Large and Small

3) Precipitation

4) Wind Speed

Table 4.1 below shows demand models for small and large houses

Table 4.1 Demand Forecasting Models for Houses

\begin{tabular}{|l|l|c|}
\hline Size of House & \multicolumn{1}{|c|}{ Demand Equation } & $\mathrm{R}^{2}$ \\
\hline Large & $\mathrm{DMD}=-63.345+4.064(\mathrm{P})+6.034(\mathrm{HDD})+$ & 0.85 \\
& $7.018(\mathrm{~S})$ & \\
\hline
\end{tabular}


Texas Tech University, Nitin Shenoy, May 2011

\begin{tabular}{|l|l|l|}
\hline Small & $\begin{array}{l}\mathrm{DMD}=-103.786+4.064(\mathrm{P})+6.034(\mathrm{HDD}) \\
+7.018(\mathrm{~S})\end{array}$ & 0.85 \\
& & \\
\hline
\end{tabular}

Different combinations of months were used in this analysis to study the propane consumption behavior for each month. However we finally decided to generate a single model for the months from October through May. Refer Appendix C.

The weather related variables had a positive coefficient as we expected. It means that the demand for propane increases with an increase in these weather variables. Size was used as a dummy variable in our analysis and hence we obtained a single model with different coefficients of regression. Another value which is of importance in the regression model is the coefficient of determination $\left(R^{2}\right)$. The $R^{2}$ value of 0.85 in the above table provides acceptable demand forecasts for both sizes of houses. Any value above 0.75 is considered to have a fairly good model fit.

SAS 9.1 was used as a tool to carry out the analysis.

The SAS output obtained was as follows: 


\begin{tabular}{|c|c|c|}
\hline \multicolumn{3}{|c|}{$\begin{array}{c}\text { Dependent Variable: Propane consumption } \\
\text { Houses }\end{array}$} \\
\hline Source & F Value & $\mathrm{Pr}>\mathrm{F}$ \\
\hline Model & 90.56 & $<.0001$ \\
\hline R-Square & & 0.85586 \\
\hline Coeff Var & & 24.40260 \\
\hline Root MSE & & 20.95677 \\
\hline Propane_consumptio & on Mean & 85.87924 \\
\hline
\end{tabular}

Figure 4.1 SAS Output for Houses

The $\mathrm{F}$ test is used to measure the overall fit of the regression model. For 95 percent significance the F- statistic should always be greater or equal to +4 . From the SAS output table we can clearly see that the F - statistic was computed as 90.56 which is significantly above 4 and hence suggests that the overall fit of the model is good. Also the P-value from the SAS output table is very small at .0001, which suggests that all the three variables in the model are accounting for a significant part of variation in demand.

\subsection{Regression Analysis Results for Mobile Homes}

Again the stepwise regression procedure from the SAS software was used to perform the regression analysis for mobile homes. The independent variables used for the analysis was:

1) Heating Degree Days

Table 3 gives the results obtained for mobile homes. 
Table 4.2 Demand Forecasting Model for Mobile Homes

\begin{tabular}{|c|c|}
\hline Demand Equation & $R^{2}$ \\
\hline $\mathrm{DMD}=8.381+3.010(\mathrm{HDD})$ & 0.80 \\
\hline
\end{tabular}

The $R^{2}$ value of 0.80 in the above table provides acceptable demand forecasts for mobile homes.

The SAS output obtained was as follows:

\begin{tabular}{|c|c|c|}
\hline \multicolumn{3}{|c|}{$\begin{array}{c}\text { Dependent Variable: Propane consumption } \\
\text { Mobile homes }\end{array}$} \\
\hline Source & F Value & $\mathrm{Pr}>\mathrm{F}$ \\
\hline Model & 129.48 & $<.0001$ \\
\hline R-Square & & 0.8068 \\
\hline Coeff Var & & 25.72142 \\
\hline Root MSE & & 12.34442 \\
\hline Propane_consumption & n Mean & 47.99278 \\
\hline
\end{tabular}

Figure 4.2 SAS output for Mobile Homes

From the SAS output table we can clearly see that the F- statistic was computed as 129.48 which suggest that the overall fit of the model is good. Also the P-value from the SAS output table is very small at .0001, which suggests that the variable HDD in the model is accounting for a significant part of variation in demand. 


\section{Chapter V}

\section{Discussion AND CONCLUSIONS}

The models developed provided a pretty significant forecast for the propane demand. Regression results were compared to the actual values obtained from the West Texas Gas, Inc., Lubbock.

\subsection{Measuring Forecasting Performance}

This is one of the most important elements of the demand forecasting process. Once we obtain a model we need to check the performance of our model to determine its accuracy. Forecasting performance is measured as a percentage of error between the actual and derived values.

Error can be calculated as follows:

$E_{T}=A_{T}-F_{T}$

where;

$E_{T}=$ error for time period $T$

$A_{T}=$ actual demand

$\mathrm{F}_{\mathrm{T}}=$ forecasted demand

However when we calculate the performance of the model we convert this error in to percentage.

The percentage error in forecast can be calculated using the following formula:

Percent Error $(\% E)=\left(A_{T}-F_{T}\right) / A_{T} * 100$

Tables 5.1 show one of such performance charts. 
Table 5.1 Forecasting Performance Chart

\begin{tabular}{|c|c|c|c|}
\hline Actual demand $\left(\mathrm{A}_{\mathrm{T}}\right)$ & $\begin{array}{c}\text { Forecasted } \\
\text { demand }\end{array}$ & $\begin{array}{c}\text { Error } \\
\left(\mathrm{E}_{\mathrm{T}}\right)\end{array}$ & \% $\mathrm{E}$ (in \%) \\
& $\left(\mathrm{F}_{\mathrm{T}}\right)$ & & \\
\hline 173.2117 & 154.5275 & 17.6842 & 10.20 \\
& & & \\
\hline 144.6417 & 144.9751 & -0.3334 & -0.2 \\
& & & \\
\hline 143.7033 & 127.7440 & 15.9593 & 11.10 \\
& & & \\
\hline & & & \\
\hline
\end{tabular}

The forecasting performance charts for large houses, small houses and mobile homes can be found in Appendix D.

In reality it is almost impossible to have a zero error model. From the above table we can clearly see that our models generate an error between 0 - $15 \%$. Anything in the range of $0-25 \%$ is considered acceptable. Also the model developed for the winter propane consumption was applied to the months from May through September when the temperatures are too high. We found that the error was too high for those months. Hence, the demand forecasting models we obtained performed significantly well for the months from October through April. 
Texas Tech University, Nitin Shenoy, May 2011

\subsection{Conclusion}

Propane demand forecasting models were developed for both houses and mobile homes. Models were generated for the months from October through May and yielded equations having high $\mathrm{R}^{2}$ values. Although different models for all the months were developed initially, we suggested a single model for all the months considered that provides an acceptable forecasting model. However we found that different number of variables had an impact on the demand for houses as compared to mobile homes. Price variable too can have an impact on the propane consumption to some extent. Inclusion of the price variable will change the forecasting equation. Also, if we consider the changes in the behavior of the consumers then we have to develop a different forecasting model.

Many improvements can be further implemented into this model. There were many limitations to our model. Price did show much significance and so was not considered in the model. However, many times price plays an important role in energy demand. Hence price is important factor that can change or effect consumer behavior. For example, when the electricity prices go up, people will always tend to use less electricity and also look for cheaper alternatives.

Also we can consider the impact of economy on the propane consumption. Economic imbalance can have a huge affect on the amount of propane consumed by a customer. Bad economy can lead to less propane demand. This might result into shutdown of various facilities that serve propane. 
The amount of propane consumed over a period of a day can be considered to find short term forecasts. During day less propane might be consumed as people often go to work. Also during the weekends more propane will be consumed as people stay within their houses.

The number of people staying in the house was another factor that could affect the propane consumption. More people in the house means more propane required for the house.

All these factors will give us a better and a more reliable model. This model can serve as a basis to design any energy demand model. 


\section{REFERENCES}

[1]Available: http://www.propanecouncil.org

[2]Available: http://home.ubalt.edu/ntsbarsh/stat-data/forecast.htm\#rasofm

[3]Available:

http://www.need.org/needpdf/infobook_activities/Seclnfo/PropaneS.pdf

[4]Sales of Natural Gas Liquids (2001) [Online]

[5]Amatya V.B., Chandrashekar M., Robinson J.B. "Residential Sector Energy-Supply :

Demand Analysis: A Modeling Approach for Developing Countries and Fuelwood

Supply Sustainability in Nepal." Energy (1993): 341-54.

[6] Al-Garni A.Z., Zubair S.M. and Nizami J.S. "A Regression Model for Electric-Energy Consumption Forecasting in Eastern Saudi Arabia." Energy (1994): 1043-1049.

[7]Anthony P., Erica M., and Karen P. "A Partial Adjustment Model of U.S. Electricity

Demand by Region, Season, and Sector." Resources for the Future (April 2009).

[8]Bala B.K. "Computer Modeling of the Rural Energy System and of $\mathrm{CO}_{2}$ Emissions for Bangladesh." Energy (1997): 999-1003.

[9] Baltagi B.H. and Griffin J.M. "Pooled Estimators vs. Their Heterogeneous Counterparts in the Context of Dynamic Demand for Gasoline." Journal of Econometrics (1997): 303-27.

[10] Bernstein M.A. and Griffin J. "Regional Differences in Price-Elasticity of Demand for Energy." The Rand Corporation Technical Report (2005). 
[11] Chase, Charles. Demand-driven Forecasting: A Structured Approach to Forecasting. Boston: Wiley, 2009.

[12] Halvorsen, Robert. Econometric Models of U.S. Energy Demand. Lexington: Lexington Books, D.C. Heath and Company, 1978.

[13] Heinemann G.T., Nordman D.A., Plant E.C. “The Relationship between Summer Weather and Summer Loads: A Regression Analysis." IEEE Transactions on Power Apparatus and Systems (1966): 1114-1154.

[14] Houthakker, H. and Taylor, L. Consumer Demand in the United States (2nd ed.). Cambridge: Harvard University Press, 1970.

[15] Le S.V. An Econometric Approach to Peak Load Forecasting. Proceedings of Electric Load Forecasting and Generating Capacity Expansion. Columbus: National Regulatory Research Institute, 1983.

[16] Leung P.S. and Miklius W. "Accuracy of Electric Power Consumption Forecasts Generated by Alternative Methods: The Case of Hawaii." Energy (1994): 311-322.

[17] Rijal K., Bansal N.K. and Grover P.D. "Rural Household Energy Demand Modeling," Energy Economics (1990): 279-288.

[18] Roger F. Electric Power Load Forecasting using Periodic Piece-wise Linear Models. Sweden: Institution of Mathematical Statistics, Technical University of Lund, 1999. [19] Smith M. L., et al. Demand Modeling for Municipally Owned Utilities. Presented at ORSA/TIMS Joint National Meeting. Atlanta: 1977. 
[20] U.S. Department of Commerce, National Oceanic and Atmospheric Administration. Texas Climatological Data. Lubbock, Texas: National Climatic Data Center, 2004.

[21] U.S. Department of Commerce, National Oceanic and Atmospheric Administration. Texas Climatological Data. Lubbock, Texas: National Climatic Data Center, 2005.

[22] U.S. Department of Commerce, National Oceanic and Atmospheric Administration. Texas Climatological Data. Lubbock, Texas: National Climatic Data Center, 2006.

[23] U.S. Department of Commerce, National Oceanic and Atmospheric Administration. Texas Climatological Data. Lubbock, Texas: National Climatic Data Center, 2007.

[24] U.S. Department of Commerce, National Oceanic and Atmospheric Administration. Texas Climatological Data. Lubbock, Texas: National Climatic Data Center, 2008.

[25] U.S. Department of Commerce, National Oceanic and Atmospheric Administration. Texas Climatological Data. Lubbock, Texas: National Climatic Data Center, 2009.

[26] Zhen F. "A Model of the Energy-Supply and Demand System at the Village Level". Energy (1993): 365-369. 


\section{APPENDIX A}

\section{DATA ON PROPANE CONSUMPTION}

1. Data on Propane Consumption by Houses (in gallons/month). Provided by West Texas Propane, Inc.

\begin{tabular}{|c|c|c|c|c|}
\hline Size of House(Sq ft) & $\mathbf{2 0 0 0}$ & $\mathbf{1 7 0 0}$ & $\mathbf{1 9 0 0}$ & $\mathbf{1 8 0 0}$ \\
\hline Month & & & & \\
\hline Nov-04 & 71.76 & 44.16 & 38.64 & 0 \\
\hline Dec-04 & 22.08 & 69 & 104.88 & 175 \\
\hline Jan-05 & 80.04 & 63.48 & 52.44 & 214 \\
\hline Feb-05 & 118.68 & 69 & 77.28 & 100 \\
\hline Mar-05 & 93.84 & 38.64 & 60.72 & 150 \\
\hline Apr-05 & 69 & 33.12 & 19.32 & 0 \\
\hline May-05 & 49.68 & 8.82 & 13.8 & 0 \\
\hline Jun-05 & 19.32 & 0 & 19.32 & 0 \\
\hline Jul-05 & 19.32 & 0 & 13.8 & 0 \\
\hline Aug-05 & 24.84 & 0 & 16.56 & 0 \\
\hline Sep-05 & 24.84 & 0 & 19.32 & 0 \\
\hline Oct-05 & 41.4 & 8.82 & 19.32 & 100 \\
\hline Nov-05 & 96.6 & 44.16 & 49.68 & 0 \\
\hline Dec-05 & 63.48 & 49.68 & 71.76 & 0 \\
\hline Jan-06 & 129.72 & 35.88 & 96.6 & 200 \\
\hline Feb-06 & 102.12 & 69 & 41.4 & 0 \\
\hline Mar-06 & 63.48 & 35.88 & 27.6 & 100 \\
\hline Apr-06 & 5.52 & 30.36 & 60.72 & 0 \\
\hline May-06 & 22.08 & 0 & 0 & 0 \\
\hline Jun-06 & 24.84 & 0 & 16.56 & 0 \\
\hline Jul-06 & 5.52 & 0 & 16.56 & 0 \\
\hline Aug-06 & 0 & 0 & 11.04 & 100 \\
\hline Sep-06 & 2.76 & 0 & 8.82 & 0 \\
\hline Oct-06 & 2.76 & 35.88 & 49.68 & 0 \\
\hline Nov-06 & 2.76 & 82.8 & 38.64 & 92 \\
\hline Dec-06 & 2.76 & 88.23 & 91.08 & 100 \\
\hline & & & & \\
\hline
\end{tabular}


Texas Tech University, Nitin Shenoy, May 2011

\begin{tabular}{|c|c|c|c|c|}
\hline Jan-07 & 5.52 & 91.08 & 110.4 & 100 \\
\hline Feb-07 & 2.76 & 55.2 & 99.36 & 250 \\
\hline Mar-07 & 2.76 & 49.68 & 35.88 & 0 \\
\hline Apr-07 & 2.76 & 44.16 & 49.68 & 100 \\
\hline May-07 & 2.76 & 0 & 19.32 & 0 \\
\hline Jun-07 & 0 & 0 & 16.56 & 0 \\
\hline Jul-07 & 0 & 0 & 19.32 & 0 \\
\hline Aug-07 & 5.52 & 0 & 13.8 & 0 \\
\hline Sep-07 & 2.76 & 0 & 19.32 & 100 \\
\hline Oct-07 & 2.76 & 8.82 & 22.08 & 60 \\
\hline Nov-07 & 33.12 & 63.48 & 55.2 & 0 \\
\hline Dec-07 & 0 & 69 & 82.8 & 100 \\
\hline Jan-08 & 0 & 121.44 & 77.28 & 150 \\
\hline Feb-08 & 0 & 93.84 & 77.28 & 120 \\
\hline Mar-08 & 0 & 80.04 & 55.2 & 100 \\
\hline Apr-08 & 0 & 24.84 & 33.12 & 0 \\
\hline May-08 & 0 & 2.76 & 24.84 & 0 \\
\hline Jun-08 & 0 & 0 & 19.32 & 0 \\
\hline Jul-08 & 19.32 & 0 & 19.32 & 0 \\
\hline Aug-08 & 19.32 & 0 & 19.32 & 0 \\
\hline Sep-08 & 16.35 & 0 & 13.8 & 105 \\
\hline Oct-08 & 30.36 & 19.32 & 2.76 & 0 \\
\hline Nov-08 & 46.92 & 41.4 & 38.64 & 0 \\
\hline Dec-08 & 157.32 & 121.44 & 91.08 & 150 \\
\hline Jan-09 & 110.4 & 85.56 & 77.28 & 130 \\
\hline Feb-09 & 135.24 & 102.12 & 88.32 & 0 \\
\hline Mar-09 & 55.2 & 33.12 & 44.16 & 100 \\
\hline
\end{tabular}

\begin{tabular}{|c|c|c|c|c|}
\hline Size of House(Sq ft) & $\mathbf{1 8 0 0}$ & $\mathbf{3 5 0 0}$ & $\mathbf{3 1 0 0}$ & $\mathbf{2 5 0 0}$ \\
\hline Month & & & & \\
\hline Nov-04 & 73 & 150 & 200 & 200 \\
\hline Dec-04 & 0 & 150 & 150 & 400 \\
\hline Jan-05 & 80 & 150 & 176 & 400 \\
\hline Feb-05 & 85 & 150 & 220 & 460 \\
\hline Mar-05 & 50 & 150 & 180 & 300 \\
\hline Apr-05 & 0 & 150 & 190 & 210 \\
\hline May-05 & 0 & 0 & 0 & 100 \\
\hline Jun-05 & 0 & 150 & 0 & 0 \\
\hline
\end{tabular}


Texas Tech University, Nitin Shenoy, May 2011

\begin{tabular}{|c|c|c|c|c|}
\hline Jul-05 & 0 & 0 & 0 & 0 \\
\hline Aug-05 & 80 & 150 & 0 & 0 \\
\hline Sep-05 & 0 & 100 & 0 & 200 \\
\hline Oct-05 & 0 & 60 & 0 & 0 \\
\hline Nov-05 & 0 & 150 & 350 & 200 \\
\hline Dec-05 & 80 & 150 & 390 & 430 \\
\hline Jan-06 & 0 & 70 & 180 & 700 \\
\hline Feb-06 & 100 & 0 & 225 & 330 \\
\hline Mar-06 & 100 & 150 & 0 & 400 \\
\hline Apr-06 & 0 & 0 & 170 & 0 \\
\hline May-06 & 0 & 0 & 0 & 370 \\
\hline Jun-06 & 0 & 0 & 0 & 0 \\
\hline Jul-06 & 75 & 0 & 0 & 0 \\
\hline Aug-06 & 0 & 150 & 200 & 430 \\
\hline Sep-06 & 0 & 0 & 0 & 0 \\
\hline Oct-06 & 55 & 110 & 0 & 220 \\
\hline Nov-06 & 0 & 0 & 0 & 170 \\
\hline Dec-06 & 115 & 124 & 300 & 350 \\
\hline Jan-07 & 75 & 150 & 400 & 440 \\
\hline Feb-07 & 110 & 150 & 320 & 640 \\
\hline Mar-07 & 0 & 0 & 250 & 350 \\
\hline Apr-07 & 32 & 50 & 110 & 250 \\
\hline May-07 & 0 & 0 & 0 & 150 \\
\hline Jun-07 & 0 & 0 & 100 & 0 \\
\hline Jul-07 & 0 & 0 & 0 & 0 \\
\hline Aug-07 & 0 & 0 & 0 & 0 \\
\hline Sep-07 & 38 & 116 & 0 & 200 \\
\hline Oct-07 & 0 & 0 & 0 & 0 \\
\hline Nov-07 & 0 & 88 & 225 & 0 \\
\hline Dec-07 & 91 & 57 & 187 & 200 \\
\hline Jan-08 & 50 & 147 & 244 & 0 \\
\hline Feb-08 & 95 & 123 & 374 & 200 \\
\hline Mar-08 & 71 & 92 & 195 & 350 \\
\hline Apr-08 & 47 & 72 & 0 & 200 \\
\hline May-08 & 0 & 0 & 100 & 150 \\
\hline Jun-08 & 0 & 0 & 117 & 0 \\
\hline Jul-08 & 0 & 0 & 0 & 0 \\
\hline Aug-08 & 0 & 0 & 0 & 0 \\
\hline Sep-08 & 49 & 0 & 101 & 200 \\
\hline Oct-08 & 0 & 150 & 0 & 150 \\
\hline
\end{tabular}


Texas Tech University, Nitin Shenoy, May 2011

\begin{tabular}{|c|c|c|c|c|}
\hline Nov-08 & 45 & 0 & 112 & 250 \\
\hline Dec-08 & 43 & 125 & 125 & 350 \\
\hline Jan-09 & 117 & 100 & 332 & 0 \\
\hline Feb-09 & 94 & 100 & 260 & 200 \\
\hline Mar-09 & 67 & 0 & 146 & 155 \\
\hline
\end{tabular}

\begin{tabular}{|c|c|c|c|c|}
\hline Size of House(Sq ft) & $\mathbf{1 9 0 0}$ & $\mathbf{1 8 7 5}$ & $\mathbf{2 9 0 0}$ & $\mathbf{1 8 0 0}$ \\
\hline Month & & & & \\
\hline Nov-04 & 180 & 57.96 & 100 & 50 \\
\hline Dec-04 & 0 & 171.12 & 0 & 20 \\
\hline Jan-05 & 220 & 138 & 100 & 0 \\
\hline Feb-05 & 100 & 118.68 & 100 & 48 \\
\hline Mar-05 & 0 & 110.4 & 100 & 0 \\
\hline Apr-05 & 0 & 41.4 & 100 & 0 \\
\hline May-05 & 0 & 44.16 & 0 & 0 \\
\hline Jun-05 & 0 & 35.88 & 0 & 0 \\
\hline Jul-05 & 150 & 27.6 & 0 & 0 \\
\hline Aug-05 & 0 & 27.6 & 0 & 0 \\
\hline Sep-05 & 100 & 19.32 & 100 & 78 \\
\hline Oct-05 & 0 & 35.88 & 0 & 0 \\
\hline Nov-05 & 100 & 19.32 & 100 & 0 \\
\hline Dec-05 & 100 & 176.64 & 0 & 90 \\
\hline Jan-06 & 100 & 102.12 & 100 & 0 \\
\hline Feb-06 & 250 & 138 & 100 & 0 \\
\hline Mar-06 & 0 & 99.36 & 100 & 0 \\
\hline Apr-06 & 0 & 27.6 & 0 & 0 \\
\hline May-06 & 0 & 22.08 & 0 & 0 \\
\hline Jun-06 & 150 & 24.84 & 0 & 0 \\
\hline Jul-06 & 0 & 30.36 & 100 & 0 \\
\hline Aug-06 & 0 & 22.08 & 0 & 0 \\
\hline Sep-06 & 0 & 13.8 & 100 & 123 \\
\hline Oct-06 & 65 & 30.36 & 0 & 50 \\
\hline Nov-06 & 84 & 52.44 & 100 & 53 \\
\hline Dec-06 & 95 & 207 & 0 & 53 \\
\hline Jan-07 & 220 & 140.76 & 100 & 0 \\
\hline Feb-07 & 100 & 276 & 100 & 64 \\
\hline Mar-07 & 0 & 71.76 & 100 & 0 \\
\hline Apr-07 & 0 & 80.04 & 100 & 73 \\
\hline May-07 & 0 & 24.84 & 0 & 0 \\
\hline
\end{tabular}


Texas Tech University, Nitin Shenoy, May 2011

\begin{tabular}{|c|c|c|c|c|}
\hline Jun-07 & 0 & 24.84 & 0 & 0 \\
\hline Jul-07 & 150 & 24.84 & 0 & 0 \\
\hline Aug-07 & 0 & 16.56 & 100 & 0 \\
\hline Sep-07 & 100 & 22.08 & 100 & 0 \\
\hline Oct-07 & 0 & 22.08 & 0 & 0 \\
\hline Nov-07 & 100 & 88.32 & 100 & 47 \\
\hline Dec-07 & 95 & 85.56 & 94 & 75 \\
\hline Jan-08 & 150 & 223.56 & 100 & 65 \\
\hline Feb-08 & 135 & 126.96 & 124.2 & 0 \\
\hline Mar-08 & 100 & 91.08 & 124 & 70 \\
\hline Apr-08 & 0 & 33.12 & 98 & 0 \\
\hline May-08 & 0 & 22.08 & 0 & 0 \\
\hline Jun-08 & 0 & 24.84 & 0 & 0 \\
\hline Jul-08 & 75 & 24.84 & 0 & 0 \\
\hline Aug-08 & 0 & 19.32 & 0 & 0 \\
\hline Sep-08 & 75 & 22.08 & 50 & 0 \\
\hline Oct-08 & 0 & 33.12 & 0 & 50 \\
\hline Nov-08 & 56 & 44.16 & 48 & 0 \\
\hline Dec-08 & 100 & 124.2 & 56 & 76 \\
\hline Jan-09 & 144 & 132.48 & 357 & 47 \\
\hline Feb-09 & 107 & 99.36 & 115 & 0 \\
\hline Mar-09 & 75 & 52.44 & 60 & 0 \\
\hline & & & & \\
\hline
\end{tabular}

\begin{tabular}{|c|c|c|c|c|}
\hline $\begin{array}{c}\text { Size of House(Sq ft) } \\
\text { Month }\end{array}$ & $\mathbf{1 4 0 0}$ & $\mathbf{2 0 0 0}$ & $\mathbf{2 1 0 0}$ & $\mathbf{2 8 0 0}$ \\
\hline Nov-04 & 100 & 55.2 & 55 & 22.08 \\
\hline Dec-04 & 100 & 151.8 & 135 & 140.76 \\
\hline Jan-05 & 150 & 107.64 & 0 & 82.8 \\
\hline Feb-05 & 150 & 99.36 & 0 & 85.56 \\
\hline Mar-05 & 150 & 91.08 & 0 & 71.76 \\
\hline Apr-05 & 0 & 13.8 & 0 & 38.64 \\
\hline May-05 & 0 & 16.56 & 0 & 11.04 \\
\hline Jun-05 & 0 & 13.8 & 0 & 0 \\
\hline Jul-05 & 0 & 16.56 & 0 & 0 \\
\hline Aug-05 & 0 & 11.04 & 0 & 0 \\
\hline Sep-05 & 100 & 11.04 & 170 & 0 \\
\hline Oct-05 & 150 & 6.56 & 100 & 5.52 \\
\hline Nov-05 & 140 & 24.84 & 0 & 77.28 \\
\hline Dec-05 & 150 & 138 & 0 & 35.88 \\
\hline
\end{tabular}


Texas Tech University, Nitin Shenoy, May 2011

\begin{tabular}{|c|c|c|c|c|}
\hline Jan-06 & 0 & 77.28 & 100 & 115.92 \\
\hline Feb-06 & 0 & 82.8 & 0 & 60.72 \\
\hline Mar-06 & 150 & 80.04 & 0 & 93.84 \\
\hline Apr-06 & 100 & 8.82 & 0 & 2.76 \\
\hline May-06 & 0 & 16.56 & 0 & 2.76 \\
\hline Jun-06 & 0 & 19.32 & 0 & 2.76 \\
\hline Jul-06 & 0 & 19.32 & 0 & 2.76 \\
\hline Aug-06 & 100 & 16.56 & 0 & 0 \\
\hline Sep-06 & 100 & 8.82 & 170 & 0 \\
\hline Oct-06 & 0 & 24.84 & 76 & 16.56 \\
\hline Nov-06 & 140 & 52.44 & 121 & 82.8 \\
\hline Dec-06 & 0 & 113.16 & 77 & 118.68 \\
\hline Jan-07 & 300 & 165.6 & 113 & 126.96 \\
\hline Feb-07 & 300 & 118.68 & 93 & 107.64 \\
\hline Mar-07 & 100 & 63.48 & 0 & 33.12 \\
\hline Apr-07 & 0 & 57.96 & 0 & 35.88 \\
\hline May-07 & 100 & 22.08 & 0 & 2.76 \\
\hline Jun-07 & 0 & 19.32 & 0 & 0 \\
\hline Jul-07 & 0 & 13.8 & 0 & 0 \\
\hline Aug-07 & 0 & 19.32 & 0 & 0 \\
\hline Sep-07 & 110 & 24.84 & 100 & 0 \\
\hline Oct-07 & 0 & 19.32 & 0 & 0 \\
\hline Nov-07 & 47 & 46.92 & 0 & 33.12 \\
\hline Dec-07 & 147 & 91.08 & 83 & 91.08 \\
\hline Jan-08 & 126 & 135.24 & 0 & 129.72 \\
\hline Feb-08 & 140 & 107.64 & 0 & 66.24 \\
\hline Mar-08 & 126 & 107.64 & 120 & 91.08 \\
\hline Apr-08 & 87 & 33.12 & 0 & 13.8 \\
\hline May-08 & 0 & 19.32 & 0 & 0 \\
\hline Jun-08 & 0 & 13.8 & 0 & 0 \\
\hline Jul-08 & 0 & 19.32 & 0 & 0 \\
\hline Aug-08 & 0 & 19.32 & 0 & 0 \\
\hline Sep-08 & 122 & 19.32 & 0 & 0 \\
\hline Oct-08 & 0 & 5.52 & 0 & 11.04 \\
\hline Nov-08 & 75 & 49.68 & 0 & 2.76 \\
\hline Dec-08 & 151 & 115.92 & 0 & 5.52 \\
\hline Jan-09 & 139 & 99.36 & 0 & 16.56 \\
\hline Feb-09 & 101 & 99.36 & 0 & 19.32 \\
\hline Mar-09 & 127 & 46.92 & 0 & 33.12 \\
\hline
\end{tabular}




\begin{tabular}{|c|c|c|c|c|}
\hline Size of House(Sq ft) & 1450 & 1700 & 1950 & 2500 \\
\hline \multicolumn{5}{|l|}{ Month } \\
\hline Nov-04 & 50 & 200 & 38.64 & 100 \\
\hline Dec-04 & 50 & 150 & 129.72 & 100 \\
\hline Jan-05 & 75 & 200 & 82.8 & 100 \\
\hline Feb-05 & 0 & 0 & 99.36 & 100 \\
\hline Mar-05 & 0 & 0 & 82.8 & 200 \\
\hline Apr-05 & 0 & 0 & 41.4 & 200 \\
\hline May-05 & 0 & 0 & 38.64 & 178 \\
\hline Jun-05 & 0 & 0 & 35.88 & 0 \\
\hline Jul-05 & 0 & 0 & 33.12 & 0 \\
\hline Aug-05 & 0 & 0 & 27.6 & 0 \\
\hline Sep-05 & 0 & 0 & 22.08 & 178 \\
\hline Oct-05 & 200 & 0 & 24.84 & 0 \\
\hline Nov-05 & 0 & 0 & 63.48 & 0 \\
\hline Dec-05 & 150 & 100 & 80.04 & 200 \\
\hline Jan-06 & 0 & 118.68 & 55.2 & 0 \\
\hline Feb-06 & 0 & 176.64 & 85.56 & 200 \\
\hline Mar-06 & 0 & 66.24 & 16.56 & 150 \\
\hline Apr-06 & 0 & 63.48 & 91.08 & 0 \\
\hline May-06 & 0 & 5.52 & 30.36 & 0 \\
\hline Jun-06 & 0 & 0 & 24.84 & 0 \\
\hline Jul-06 & 0 & 0 & 24.84 & 0 \\
\hline Aug-06 & 0 & 0 & 16.56 & 100 \\
\hline Sep-06 & 125 & 0 & 19.32 & 0 \\
\hline Oct-06 & 100 & 22.08 & 33.12 & 100 \\
\hline Nov-06 & 0 & 102.12 & 35.88 & 100 \\
\hline Dec-06 & 66 & 212.52 & 60.72 & 100 \\
\hline Jan-07 & 106 & 234.6 & 52.44 & 450 \\
\hline Feb-07 & 126 & 46.92 & 104.88 & 174 \\
\hline Mar-07 & 74 & 220.8 & 35.88 & 0 \\
\hline Apr-07 & 0 & 99.36 & 55.2 & 150 \\
\hline May-07 & 0 & 22.08 & 27.6 & 0 \\
\hline Jun-07 & 0 & 0 & 24.84 & 0 \\
\hline Jul-07 & 0 & 0 & 22.08 & 0 \\
\hline Aug-07 & 0 & 0 & 19.32 & 0 \\
\hline Sep-07 & 0 & 0 & 19.32 & 105 \\
\hline Oct-07 & 117 & 2.76 & 24.84 & 84 \\
\hline
\end{tabular}




\begin{tabular}{|c|c|c|c|c|}
\hline Nov-07 & 0 & 96.6 & 46.92 & 50 \\
\hline Dec-07 & 84 & 107.64 & 69 & 127 \\
\hline Jan-08 & 47 & 231.84 & 80.04 & 150 \\
\hline Feb-08 & 141 & 146.28 & 66.24 & 150 \\
\hline Mar-08 & 65 & 96.6 & 52.44 & 150 \\
\hline Apr-08 & 0 & 33.12 & 35.88 & 150 \\
\hline May-08 & 0 & 11.04 & 35.88 & 0 \\
\hline Jun-08 & 0 & 0 & 19.32 & 0 \\
\hline Jul-08 & 0 & 0 & 19.32 & 0 \\
\hline Aug-08 & 0 & 0 & 19.32 & 0 \\
\hline Sep-08 & 0 & 0 & 24.84 & 150 \\
\hline Oct-08 & 100 & 5.52 & 30.36 & 0 \\
\hline Nov-08 & 0 & 38.64 & 22.08 & 118 \\
\hline Dec-08 & 125 & 2.76 & 55.2 & 150 \\
\hline Jan-09 & 100 & 2.76 & 44.16 & 150 \\
\hline Feb-09 & 0 & 0 & 35.88 & 204 \\
\hline Mar-09 & 0 & 0 & 22.08 & 145 \\
\hline
\end{tabular}

\begin{tabular}{|c|c|c|c|c|}
\hline Size of House(Sq ft) & $\mathbf{3 5 0 0}$ & $\mathbf{2 5 0 0}$ & $\mathbf{1 2 0 0}$ & $\mathbf{1 1 0 0}$ \\
\hline Month & & & & \\
\hline Nov-04 & 132.48 & & & 46.92 \\
\hline Dec-04 & 229.08 & 199.9 & 99.36 & 107.64 \\
\hline Jan-05 & 209.76 & 80.4 & 88.32 & 77.28 \\
\hline Feb-05 & 184.92 & 8.58 & 41.4 & 69 \\
\hline Mar-05 & 152.9 & 27.6 & 27.6 & 55.2 \\
\hline Apr-05 & 151.8 & 2.76 & 8.53 & 46.92 \\
\hline May-05 & 107.64 & 2.76 & 11.04 & 24.84 \\
\hline Jun-05 & 98.97 & 2.76 & 13.8 & 19.32 \\
\hline Jul-05 & 102.12 & 2.76 & 5.52 & 8.28 \\
\hline Aug-05 & 91.08 & 5.52 & 2.76 & 16.56 \\
\hline Sep-05 & 44.16 & 5.52 & 2.76 & 24.84 \\
\hline Oct-05 & 99.36 & 8.58 & 5.52 & 35.88 \\
\hline Nov-05 & 132.48 & 107.64 & 72.4 & 88.32 \\
\hline Dec-05 & 240.12 & 107.64 & 63.48 & 90 \\
\hline Jan-06 & 259.63 & 143.52 & 60.72 & 66.24 \\
\hline Feb-06 & 176.64 & 80.04 & 41.4 & 77.28 \\
\hline Mar-06 & 171.12 & 8.58 & 11.04 & 5.52 \\
\hline Apr-06 & 71.76 & 2.76 & 11.04 & 13.8 \\
\hline May-06 & 33.12 & 2.76 & 2.76 & 19.32 \\
\hline
\end{tabular}


Texas Tech University, Nitin Shenoy, May 2011

\begin{tabular}{|c|c|c|c|c|}
\hline Jun-06 & 49.68 & 2.76 & 2.76 & 16.56 \\
\hline Jul-06 & 115.92 & 2.76 & 5.52 & 24.84 \\
\hline Aug-06 & 91.08 & 2.76 & 5.52 & 13.8 \\
\hline Sep-06 & 78.1 & 5.52 & 35.88 & 30.36 \\
\hline Oct-06 & 57.96 & 8.58 & 35.88 & 30.36 \\
\hline Nov-06 & 135.24 & 27.6 & 88.32 & 80.04 \\
\hline Dec-06 & 218.04 & 74.52 & 96.6 & 101.02 \\
\hline Jan-07 & 251.16 & 143.52 & 104.88 & 93.5 \\
\hline Feb-07 & 254.64 & 27.6 & 91.08 & 27.6 \\
\hline Mar-07 & 135.24 & 33.12 & 57.96 & 35.88 \\
\hline Apr-07 & 129.72 & 2.76 & 57.96 & 16.56 \\
\hline May-07 & 110.4 & 2.76 & 35.88 & 2.76 \\
\hline Jun-07 & 44.16 & 2.76 & 19.32 & 5.52 \\
\hline Jul-07 & 33.12 & 2.76 & 16.56 & 13.8 \\
\hline Aug-07 & 30.36 & 2.76 & 13.8 & 19.32 \\
\hline Sep-07 & 41.4 & 5.52 & 19.32 & 19.32 \\
\hline Oct-07 & 38.64 & 2.76 & 30.36 & 41.4 \\
\hline Nov-07 & 66.12 & 8.28 & 63.48 & 41.4 \\
\hline Dec-07 & 151.8 & 107.64 & 60.72 & 74.52 \\
\hline Jan-08 & 447.12 & 99.36 & 102.12 & 53.91 \\
\hline Feb-08 & 124.2 & 74.52 & 41.4 & 38.64 \\
\hline Mar-08 & 96.6 & 33.12 & 44.16 & 16.56 \\
\hline Apr-08 & 44.16 & 8.28 & 24.84 & 2.76 \\
\hline May-08 & 42.13 & 2.76 & 24.84 & 2.76 \\
\hline Jun-08 & 38.64 & 2.76 & 11.04 & 2.76 \\
\hline Jul-08 & 35.88 & 2.76 & 2.76 & 2.76 \\
\hline Aug-08 & 30.36 & 2.76 & 5.52 & 2.76 \\
\hline Sep-08 & 35.88 & 5.52 & 5.52 & 0 \\
\hline Oct-08 & 22.08 & 2.76 & 35.88 & 8.28 \\
\hline Nov-08 & 69 & 2.76 & 44.16 & 19.32 \\
\hline Dec-08 & 124.2 & 115.92 & 91.08 & 69 \\
\hline Jan-09 & 104.88 & 57.96 & 88.32 & 60.72 \\
\hline
\end{tabular}


Texas Tech University, Nitin Shenoy, May 2011

\begin{tabular}{|c|c|c|c|}
\hline Size of House(Sq ft) & 3200 & 3000 & 4215 \\
\hline \multicolumn{4}{|l|}{ Month } \\
\hline Nov-04 & & 69 & \\
\hline Dec-04 & 162.84 & 223.56 & 187.4 \\
\hline Jan-05 & 110.4 & 121.44 & 204.9 \\
\hline Feb-05 & 107.64 & 107.64 & 200.1 \\
\hline Mar-05 & 82.8 & 121.44 & 243.6 \\
\hline Apr-05 & 63.48 & 44.16 & 101.02 \\
\hline May-05 & 35.88 & 24.84 & 98.07 \\
\hline Jun-05 & 8.28 & 11.04 & 77.28 \\
\hline Jul-05 & 5.52 & 8.28 & 51.01 \\
\hline Aug-05 & 16.65 & 11.04 & 56.93 \\
\hline Sep-05 & 19.32 & 8.28 & 55.2 \\
\hline Oct-05 & 22.08 & 16.56 & 116.93 \\
\hline Nov-05 & 57.96 & 52.44 & 138.54 \\
\hline Dec-05 & 162.84 & 179.4 & 196.43 \\
\hline Jan-06 & 171.12 & 162.84 & 207.53 \\
\hline Feb-06 & 151.8 & 102.12 & 184.92 \\
\hline Mar-06 & 71.76 & 71.76 & 118.06 \\
\hline Apr-06 & 63.84 & 13.8 & 74.51 \\
\hline May-06 & 19.32 & 2.73 & 63.82 \\
\hline Jun-06 & 11.04 & 11.04 & 49.97 \\
\hline Jul-06 & 13.8 & 11.04 & 51.03 \\
\hline Aug-06 & 16.56 & 8.28 & 63.59 \\
\hline Sep-06 & 16.56 & 5.52 & 58.4 \\
\hline Oct-06 & 49.68 & 22.08 & 67.89 \\
\hline Nov-06 & 52.44 & 49.68 & 113.52 \\
\hline Dec-06 & 165.5 & 129.72 & 293.67 \\
\hline Jan-07 & 223.56 & 198.72 & 259.44 \\
\hline Feb-07 & 165.6 & 143.52 & 223.56 \\
\hline Mar-07 & 63.48 & 49.68 & 113.59 \\
\hline Apr-07 & 69 & 55.2 & 93.84 \\
\hline May-07 & 19.32 & 11.04 & 102.12 \\
\hline Jun-07 & 16.56 & 5.52 & 69 \\
\hline Jul-07 & 11.04 & 8.28 & 52.44 \\
\hline Aug-07 & 11.07 & 5.52 & 41.4 \\
\hline Sep-07 & 13.8 & 8.28 & 57.96 \\
\hline Oct-07 & 22.08 & 5.52 & 55.2 \\
\hline Nov-07 & 57.96 & 63.48 & 110.4 \\
\hline Dec-07 & 149.04 & 91.08 & 113.16 \\
\hline
\end{tabular}




\begin{tabular}{|c|c|c|c|}
\hline Jan-08 & 193.2 & 176.64 & 223.56 \\
\hline Feb-08 & 135.24 & 113.16 & 198.72 \\
\hline Mar-08 & 104.88 & 71.76 & 116.82 \\
\hline Apr-08 & 41.4 & 19.32 & 82.53 \\
\hline May-08 & 27.6 & 5.52 & 69 \\
\hline Jun-08 & 13.8 & 8.28 & 49.68 \\
\hline Jul-08 & 8.28 & 8.28 & 52.44 \\
\hline Aug-08 & 11.04 & 8.28 & 60.72 \\
\hline Sep-08 & 16.56 & 8.28 & 57.96 \\
\hline Oct-08 & 33.12 & 16.56 & 80.04 \\
\hline Nov-08 & 63.48 & 49.68 & 71.76 \\
\hline Dec-08 & 182.16 & 135.24 & 287.04 \\
\hline Jan-09 & 160.08 & 138 & 212.52 \\
\hline & & & \\
\hline & &
\end{tabular}

\section{Data on Consumption of Propane by Mobile Homes (in gallons/month)}

\begin{tabular}{|c|c|c|c|c|c|c|}
\hline $\begin{array}{c}\text { Size of Mobile } \\
\text { Homes(Sq ft) }\end{array}$ & $\mathbf{2 0 0 0}$ & $\mathbf{1 7 0 0}$ & $\mathbf{1 9 0 0}$ & $\mathbf{1 8 0 0}$ & $\mathbf{1 9 0 0}$ & $\mathbf{1 9 5 0}$ \\
\hline Month & & & & & & \\
\hline Dec-04 & 22.08 & 69 & 104.88 & 20 & 0 & 129.72 \\
\hline Jan-05 & 80.04 & 63.48 & 52.44 & 0 & 220 & 82.8 \\
\hline Feb-05 & 118.68 & 69 & 77.28 & 48 & 100 & 99.36 \\
\hline Mar-05 & 93.84 & 38.64 & 60.72 & 0 & 0 & 82.8 \\
\hline Oct-05 & 41.4 & 8.82 & 19.32 & 0 & 0 & 24.84 \\
\hline Nov-05 & 96.6 & 44.16 & 49.68 & 0 & 100 & 63.48 \\
\hline Dec-05 & 63.48 & 49.68 & 71.76 & 90 & 100 & 80.04 \\
\hline Jan-06 & 129.72 & 35.88 & 96.6 & 0 & 100 & 55.2 \\
\hline Feb-06 & 102.12 & 69 & 41.4 & 0 & 250 & 85.56 \\
\hline Mar-06 & 63.48 & 35.88 & 27.6 & 0 & 0 & 16.56 \\
\hline Oct-06 & 2.76 & 35.88 & 49.68 & 50 & 65 & 33.12 \\
\hline Nov-06 & 2.76 & 82.8 & 38.64 & 53 & 84 & 35.88 \\
\hline Dec-06 & 2.76 & 88.23 & 91.08 & 53 & 95 & 60.72 \\
\hline Jan-07 & 5.52 & 91.08 & 110.4 & 0 & 220 & 52.44 \\
\hline Feb-07 & 2.76 & 55.2 & 99.36 & 64 & 100 & 104.88 \\
\hline Mar-07 & 2.76 & 49.68 & 35.88 & 0 & 0 & 35.88 \\
\hline Oct-07 & 2.76 & 8.82 & 22.08 & 0 & 0 & 24.84 \\
\hline Nov-07 & 33.12 & 63.48 & 55.2 & 47 & 100 & 46.92 \\
\hline & & & & & & \\
\hline & & & 0 & \\
\hline
\end{tabular}


Texas Tech University, Nitin Shenoy, May 2011

\begin{tabular}{|c|c|c|c|c|c|c|}
\hline Dec-07 & 0 & 69 & 82.8 & 75 & 95 & 69 \\
\hline Jan-08 & 0 & 121.44 & 77.28 & 65 & 150 & 80.04 \\
\hline Feb-08 & 0 & 93.84 & 77.28 & 0 & 135 & 66.24 \\
\hline Mar-08 & 0 & 80.04 & 55.2 & 70 & 100 & 52.44 \\
\hline Oct-08 & 30.36 & 19.32 & 2.76 & 50 & 0 & 30.36 \\
\hline Nov-08 & 46.92 & 41.4 & 38.64 & 0 & 56 & 22.08 \\
\hline Dec-08 & 157.32 & 121.44 & 91.08 & 76 & 100 & 55.2 \\
\hline
\end{tabular}

3. Data on Temperature(in F), Heating Degree days (in days), Cooling Degree days (in days).

Provided by National Climatic Data Center, U.S. Departmental of Commerce.

\begin{tabular}{|c|c|c|c|}
\hline Month & Temperature & Heating degree days & Cooling degree days \\
\hline Dec-04 & 42.3 & 697 & 0 \\
\hline Jan-05 & 43.5 & 661 & 0 \\
\hline Feb-05 & 46 & 525 & 0 \\
\hline Mar-05 & 50.5 & 444 & 0 \\
\hline Apr-05 & 59.4 & 190 & 28 \\
\hline May-05 & 69 & 80 & 210 \\
\hline Jun-05 & 79 & 0 & 427 \\
\hline Jul-05 & 79.4 & 0 & 457 \\
\hline Aug-05 & 77.1 & 0 & 382 \\
\hline Sep-05 & 76 & 6 & 343 \\
\hline Oct-05 & 61.9 & 161 & 72 \\
\hline Nov-05 & 52.2 & 384 & 6 \\
\hline Dec-05 & 41.4 & 726 & 0 \\
\hline Jan-06 & 47.3 & 542 & 0 \\
\hline Feb-06 & 45.1 & 553 & 0 \\
\hline Mar-06 & 53.9 & 347 & 11 \\
\hline Apr-06 & 66.2 & 72 & 114 \\
\hline May-06 & 73.7 & 21 & 297 \\
\hline Jun-06 & 80.5 & 0 & 471 \\
\hline Jul-06 & 82.9 & 0 & 561 \\
\hline Aug-06 & 80.6 & 22 & 493 \\
\hline Sep-06 & 68.6 & & 137 \\
\hline
\end{tabular}


Texas Tech University, Nitin Shenoy, May 2011

\begin{tabular}{|c|c|c|c|}
\hline Oct-06 & 61 & 181 & 61 \\
\hline Nov-06 & 51.9 & 389 & 4 \\
\hline Dec-06 & 41.5 & 720 & 0 \\
\hline Jan-07 & 36.4 & 879 & 0 \\
\hline Feb-07 & 43.6 & 593 & 0 \\
\hline Mar-07 & 55.7 & 286 & 11 \\
\hline Apr-07 & 55.8 & 280 & 12 \\
\hline May-07 & 66.8 & 47 & 110 \\
\hline Jun-07 & 74.6 & 1 & 295 \\
\hline Jul-07 & 77.5 & 0 & 395 \\
\hline Aug-07 & 79.7 & 0 & 463 \\
\hline Sep-07 & 74.2 & 0 & 285 \\
\hline Oct-07 & 65.1 & 105 & 116 \\
\hline Nov-07 & 50.7 & 422 & 0 \\
\hline Dec-07 & 41.9 & 713 & 0 \\
\hline Jan-08 & 40.5 & 752 & 0 \\
\hline Feb-08 & 47.4 & 506 & 0 \\
\hline Mar-08 & 52.8 & 382 & 11 \\
\hline Apr-08 & 60.7 & 175 & 53 \\
\hline May-08 & 70.2 & 50 & 222 \\
\hline Jun-08 & 80.9 & 0 & 485 \\
\hline Jul-08 & 79.3 & 0 & 448 \\
\hline Aug-08 & 77.6 & 0 & 396 \\
\hline Sep-08 & 68.7 & 5 & 121 \\
\hline Oct-08 & 61.3 & 144 & 37 \\
\hline Nov-08 & 51.1 & 410 & 2 \\
\hline Dec-08 & 42.6 & 687 & 0 \\
\hline & & & \\
\hline
\end{tabular}


4. Data on Precipitation (in inches) and Wind Speed (in $\mathrm{m} / \mathrm{sec}$ ).

Provided by National Climatic Data Center, U.S. Departmental of Commerce.

\begin{tabular}{|c|c|c|}
\hline Month & Wind Speed & Precipitation \\
\hline Nov-04 & 11.1 & 0.69 \\
\hline Dec-04 & 11.3 & 1.33 \\
\hline Jan-05 & 10.6 & 1.32 \\
\hline Feb-05 & 10.3 & 0.73 \\
\hline Mar-05 & 13.2 & 0.27 \\
\hline Apr-05 & 14.1 & 2.24 \\
\hline May-05 & 12.5 & 1.84 \\
\hline Jun-05 & 13.9 & 2.41 \\
\hline Jul-05 & 10.7 & 2.01 \\
\hline Aug-05 & 9.2 & 0.28 \\
\hline Sep-05 & 10.4 & 2.61 \\
\hline Oct-05 & 9.7 & 0 \\
\hline Nov-05 & 11.3 & 0 \\
\hline Dec-05 & 10.9 & 0 \\
\hline Jan-06 & 12.9 & 0.18 \\
\hline Feb-06 & 12.6 & 1.62 \\
\hline Mar-06 & 14.4 & 0.77 \\
\hline Apr-06 & 14.1 & 2.15 \\
\hline May-06 & 12.6 & 0.57 \\
\hline Jun-06 & 12.3 & 0.62 \\
\hline Jul-06 & 10.6 & 1.51 \\
\hline Aug-06 & 10.1 & 4.87 \\
\hline Sep-06 & 10.3 & 1.3 \\
\hline Oct-06 & 11.4 & 0.26 \\
\hline Nov-06 & 11.7 & 1.71 \\
\hline Dec-06 & 11.4 & 1.12 \\
\hline Jan-07 & 11 & 0.36 \\
\hline Feb-07 & 12.8 & 5.94 \\
\hline Mar-07 & 11.7 & 1.23 \\
\hline Apr-07 & 13 & 5.35 \\
\hline May-07 & 11 & 3.39 \\
\hline Jun-07 & 10.6 & 0.94 \\
\hline Jul-07 & 8.1 & 1.99 \\
\hline & & \\
\hline
\end{tabular}


Texas Tech University, Nitin Shenoy, May 2011

\begin{tabular}{|c|c|c|}
\hline Aug-07 & 10.6 & 2.2 \\
\hline Sep-07 & 9.7 & 0.28 \\
\hline Oct-07 & 11.5 & 0.2 \\
\hline Nov-07 & 9.8 & 0.94 \\
\hline Dec-07 & 11.2 & 0.07 \\
\hline Jan-08 & 12.8 & 0.72 \\
\hline Feb-08 & 12.7 & 0.1 \\
\hline Mar-08 & 15 & 1.07 \\
\hline Apr-08 & 14.4 & 5.32 \\
\hline May-08 & 13 & 2.91 \\
\hline Jun-08 & 14.2 & 1.77 \\
\hline Jul-08 & 10.5 & 3.48 \\
\hline Aug-08 & 8.7 & 8.7 \\
\hline Sep-08 & 7.9 & 3.77 \\
\hline Oct-08 & 10.5 & 0.08 \\
\hline Nov-08 & 10.6 & 0.01 \\
\hline
\end{tabular}


Texas Tech University, Nitin Shenoy, May 2011

\section{APPENDIX B}

SCATter Plots

\section{Scatter plots for Demand versus Cooling Degree Days}

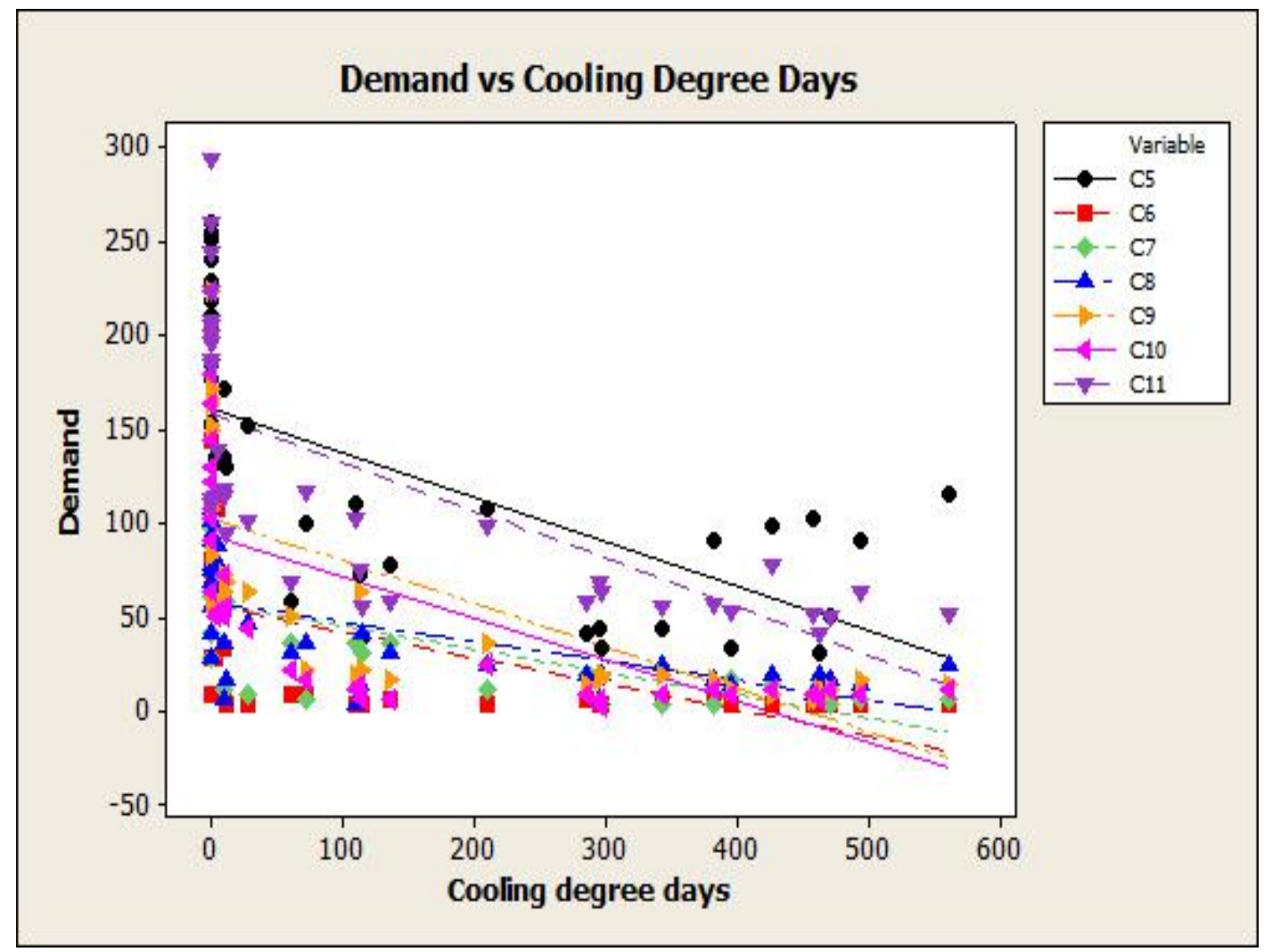




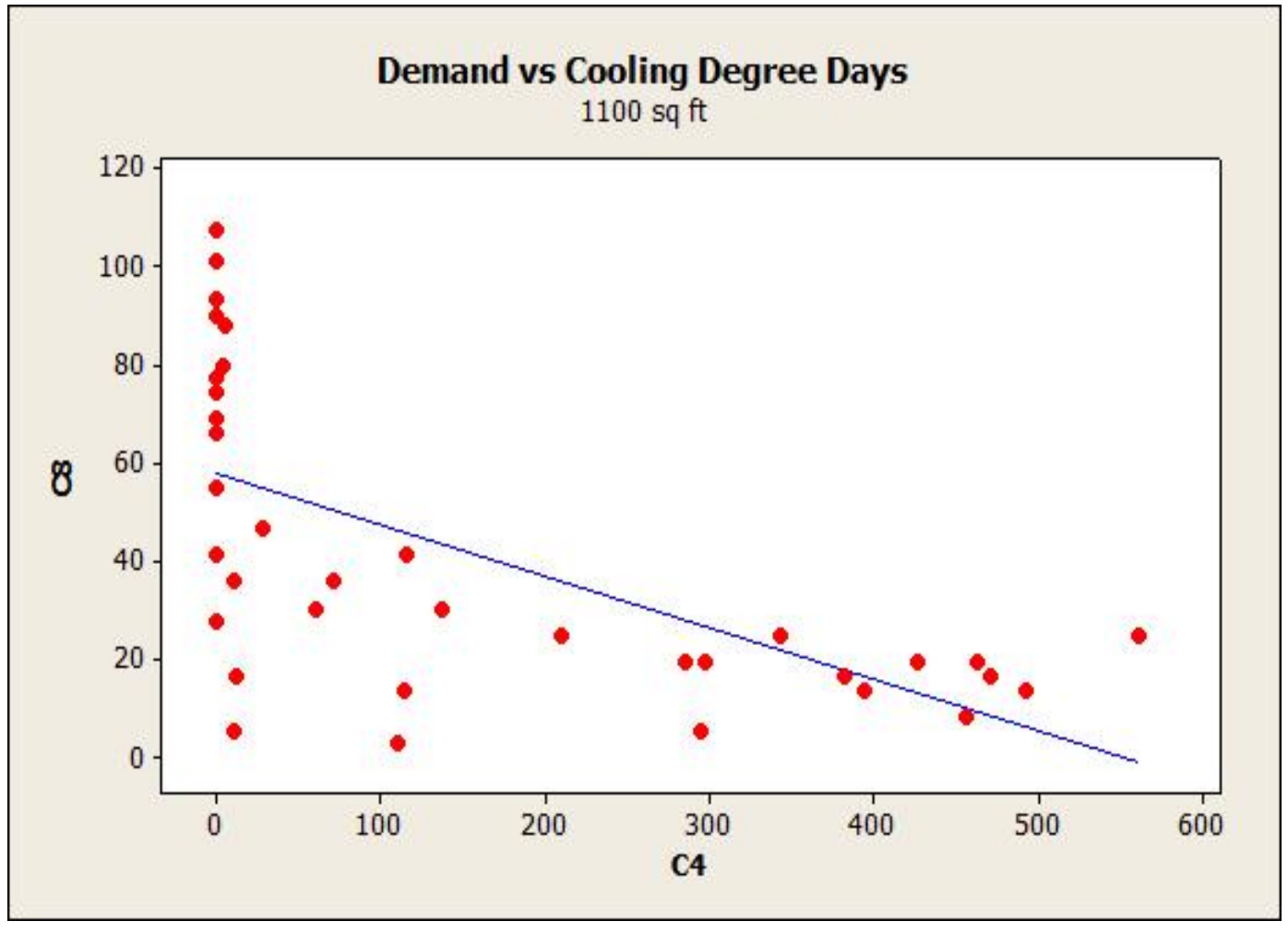


Texas Tech University, Nitin Shenoy, May 2011

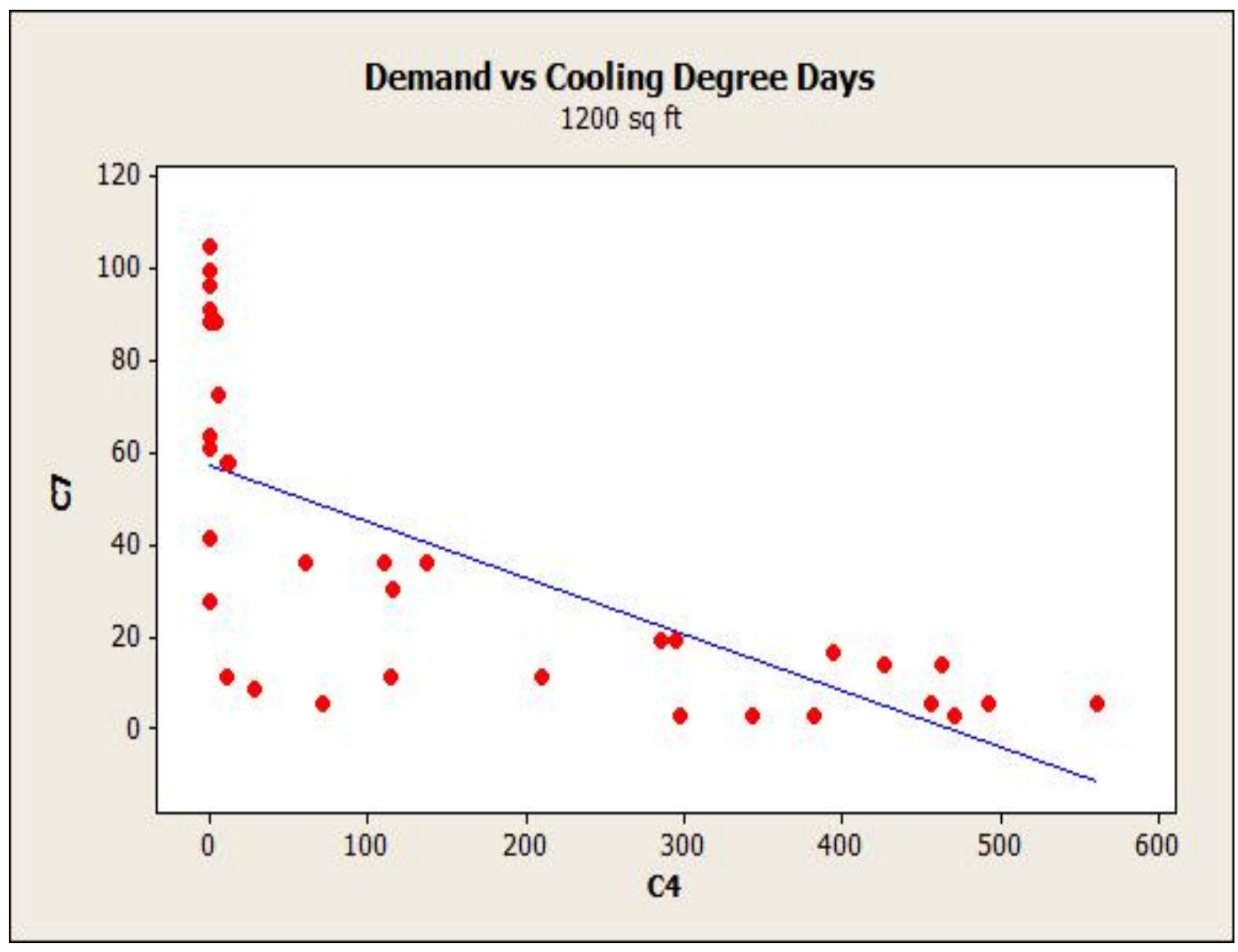



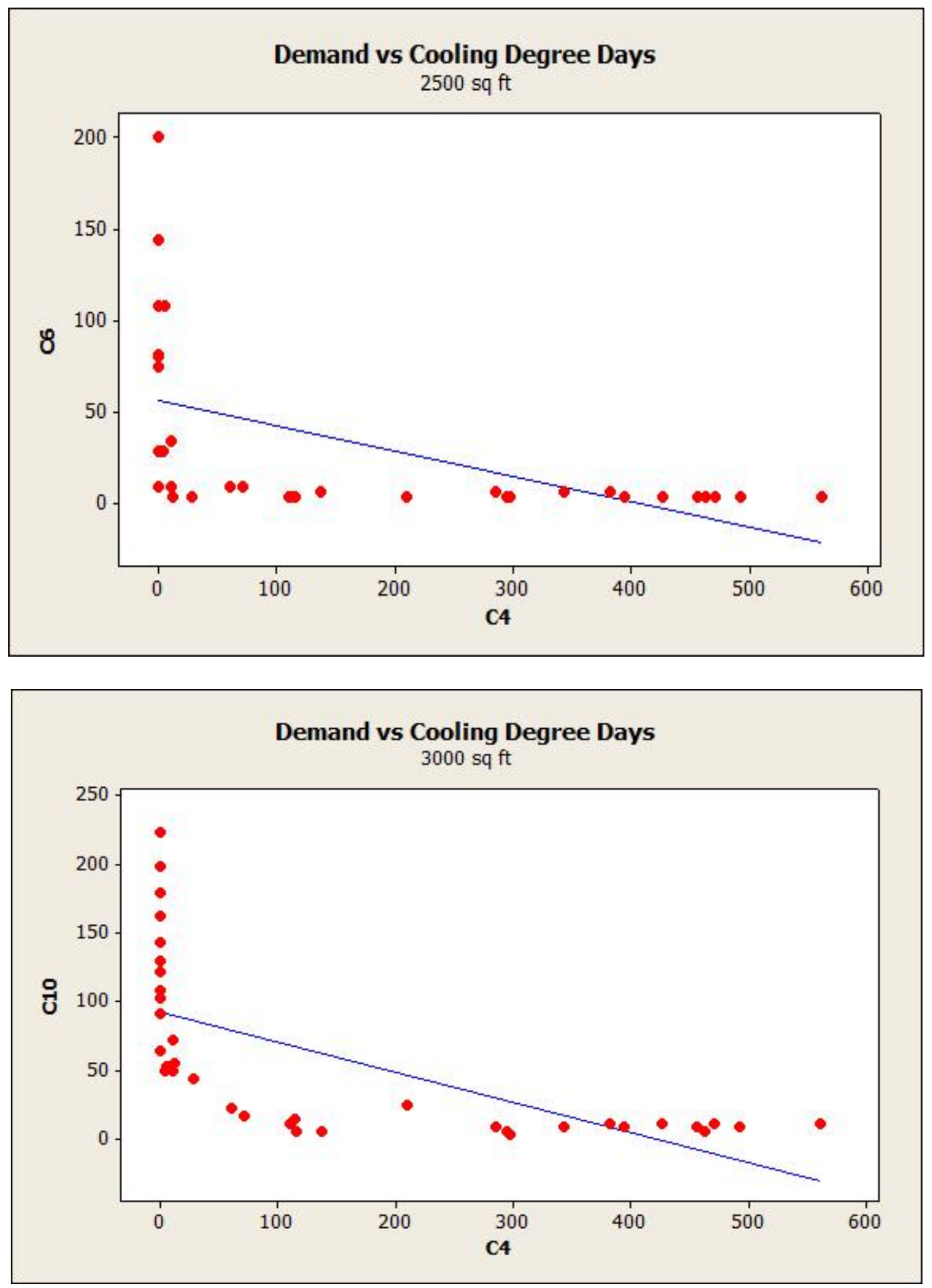
Texas Tech University, Nitin Shenoy, May 2011
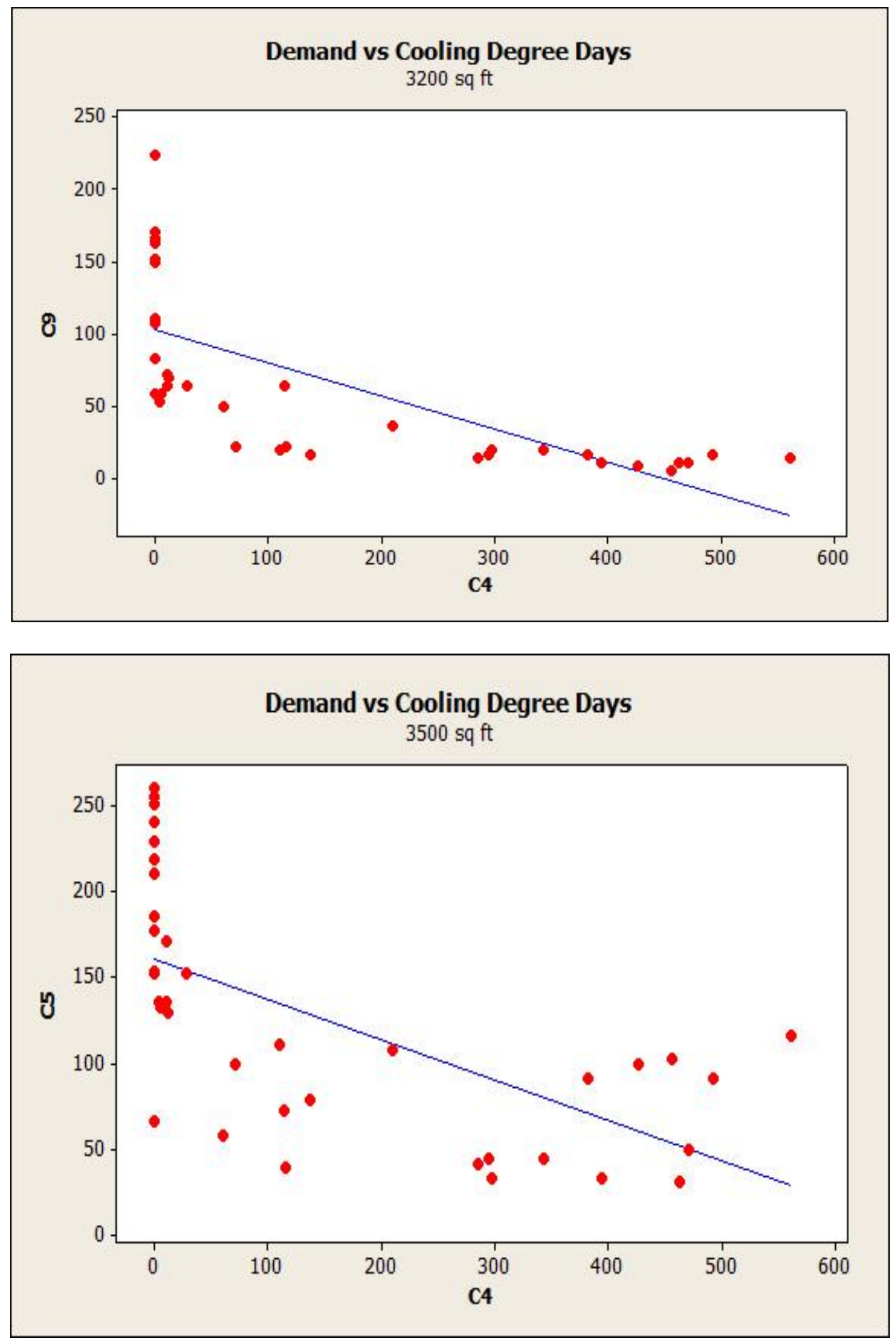
Texas Tech University, Nitin Shenoy, May 2011

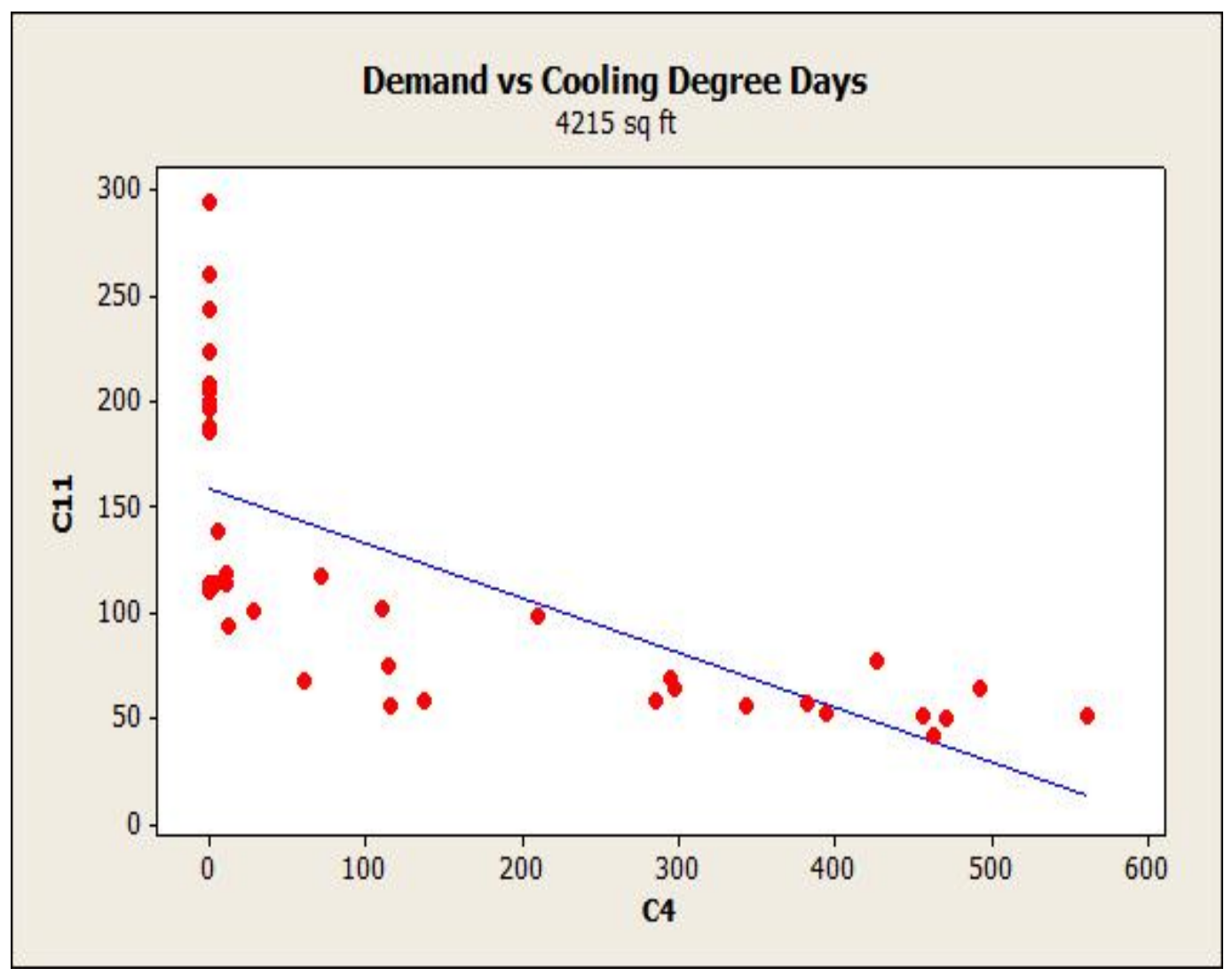


2. Scatter plots for Demand versus Heating Degree Days

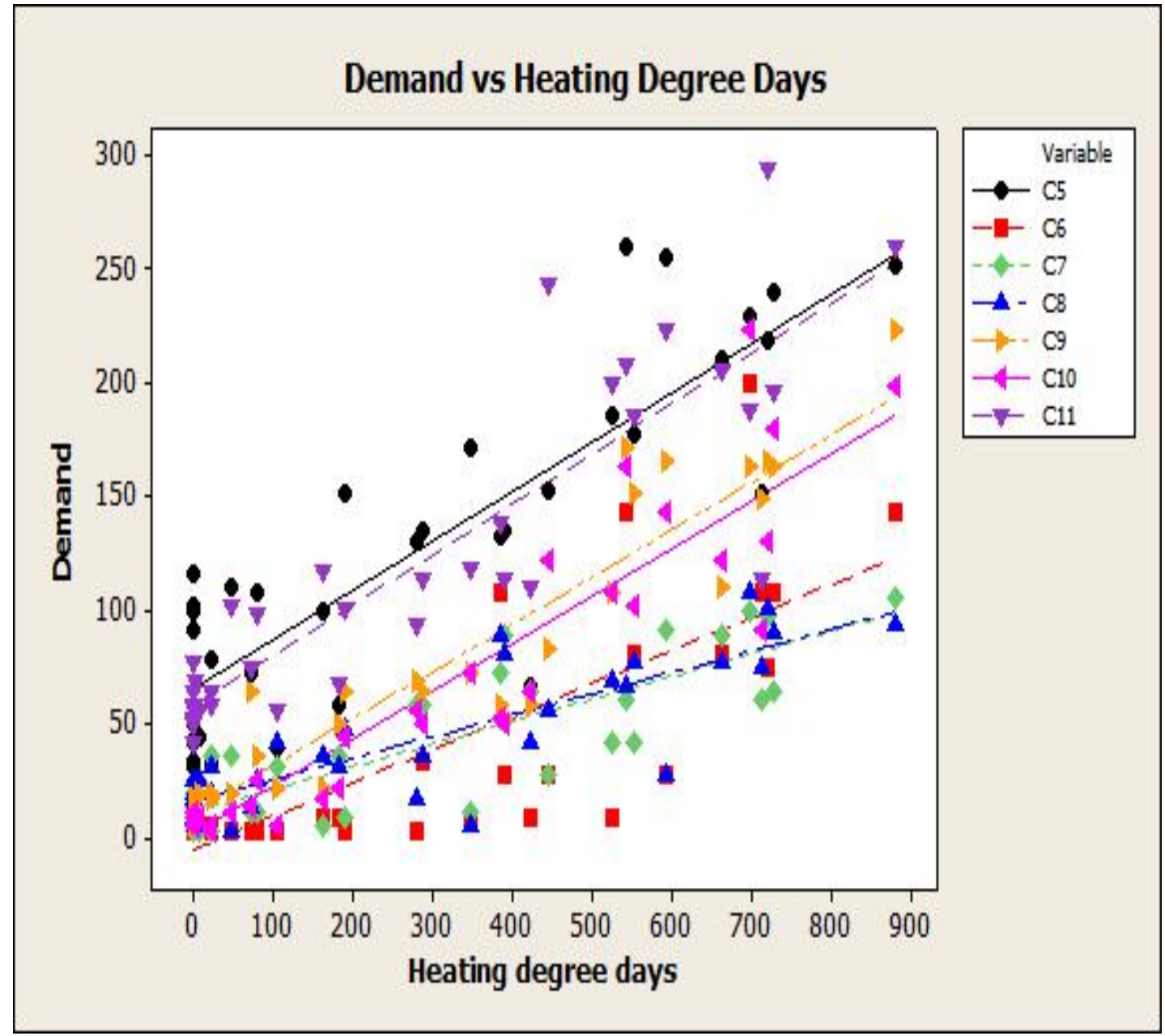


Texas Tech University, Nitin Shenoy, May 2011
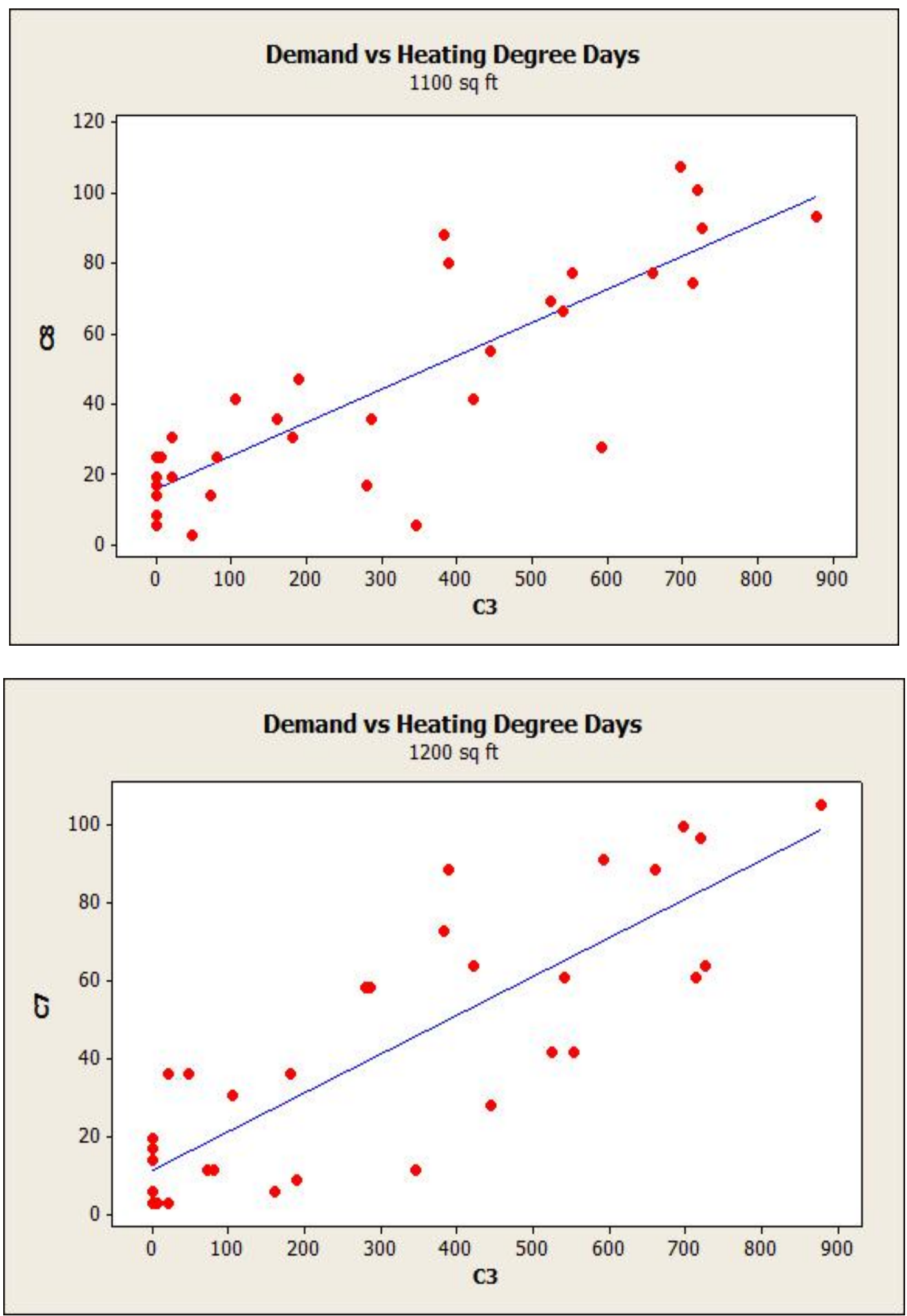
Texas Tech University, Nitin Shenoy, May 2011
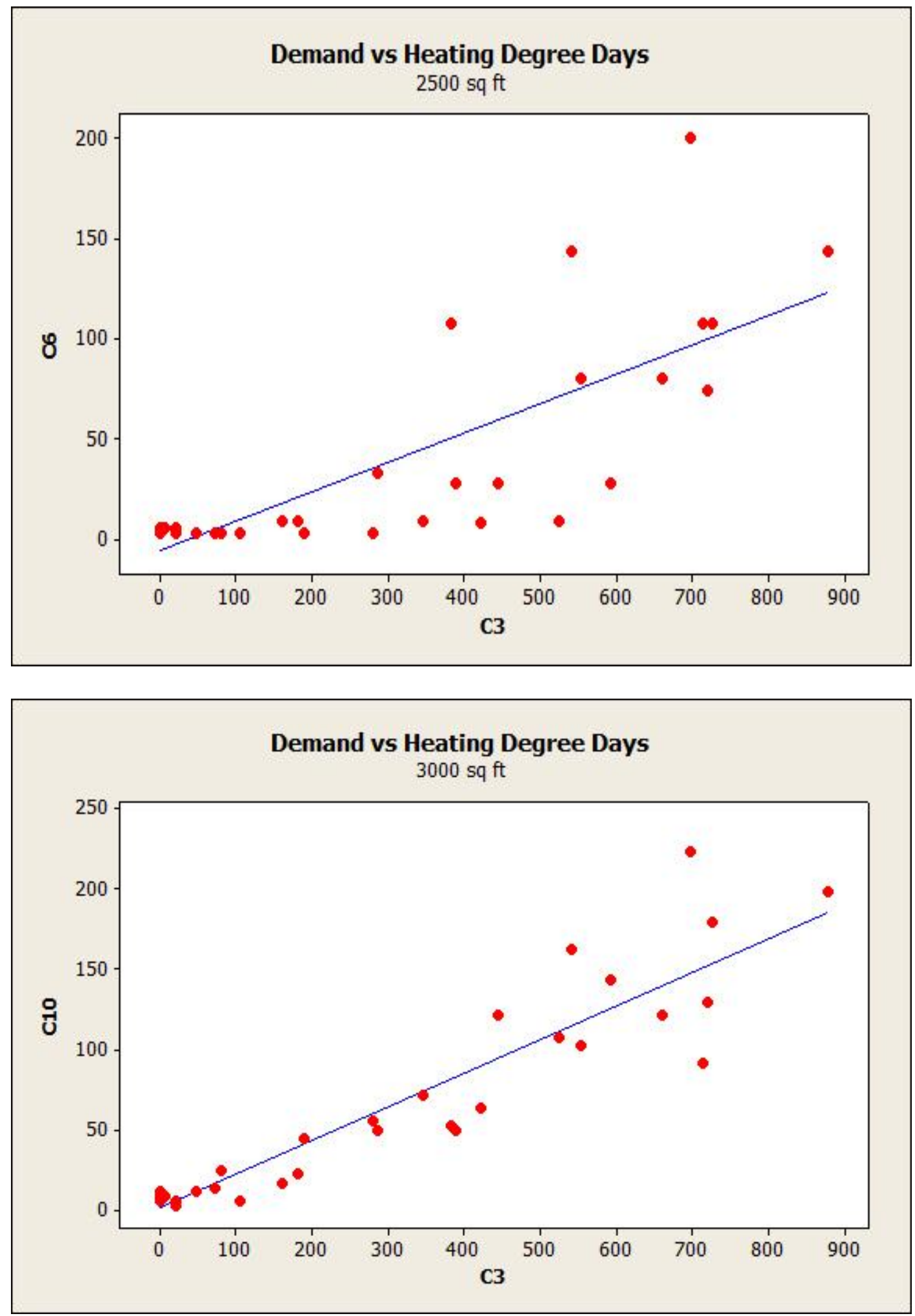
Texas Tech University, Nitin Shenoy, May 2011
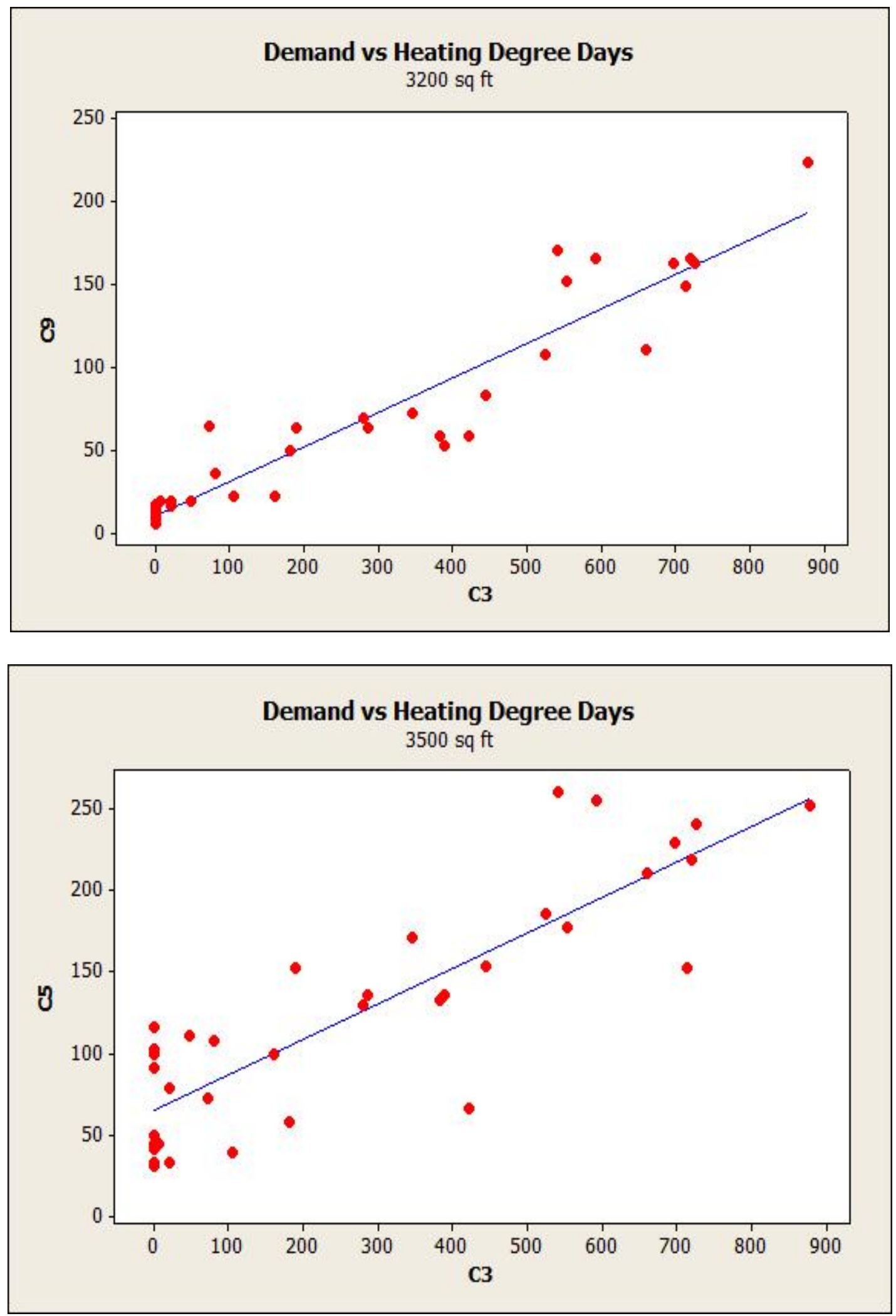
Texas Tech University, Nitin Shenoy, May 2011

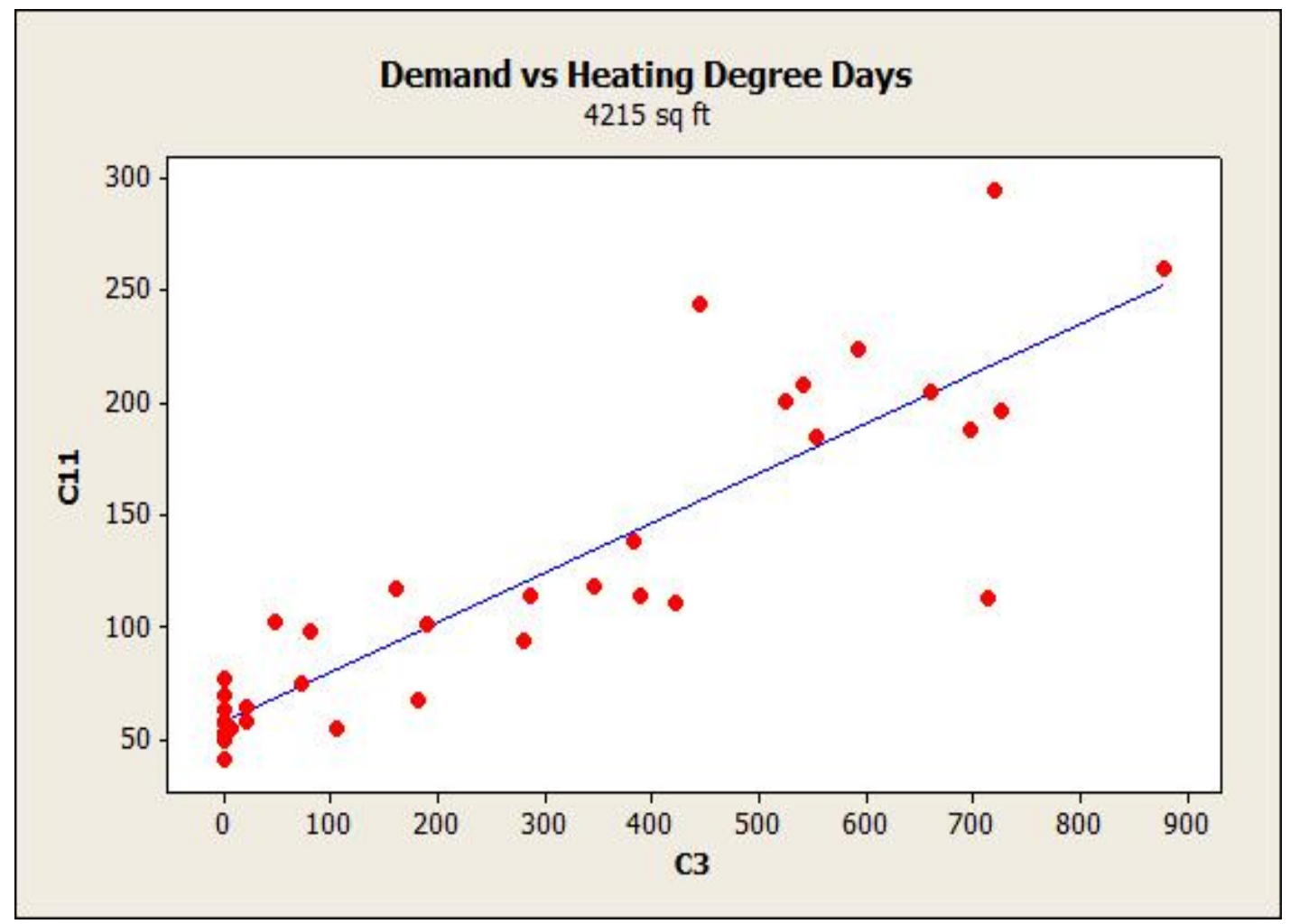




\section{Scatter plots for Demand versus Temperature}

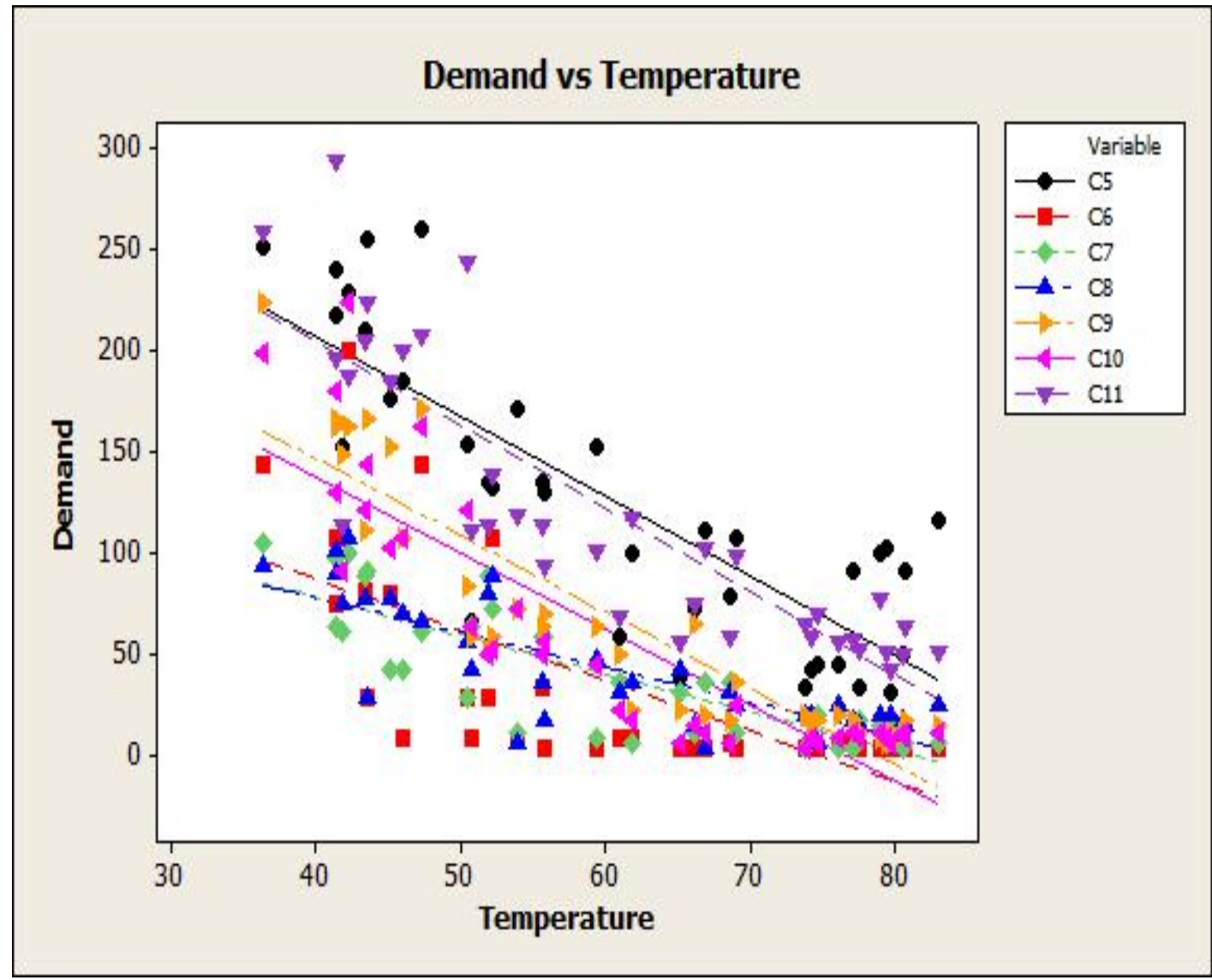


Texas Tech University, Nitin Shenoy, May 2011
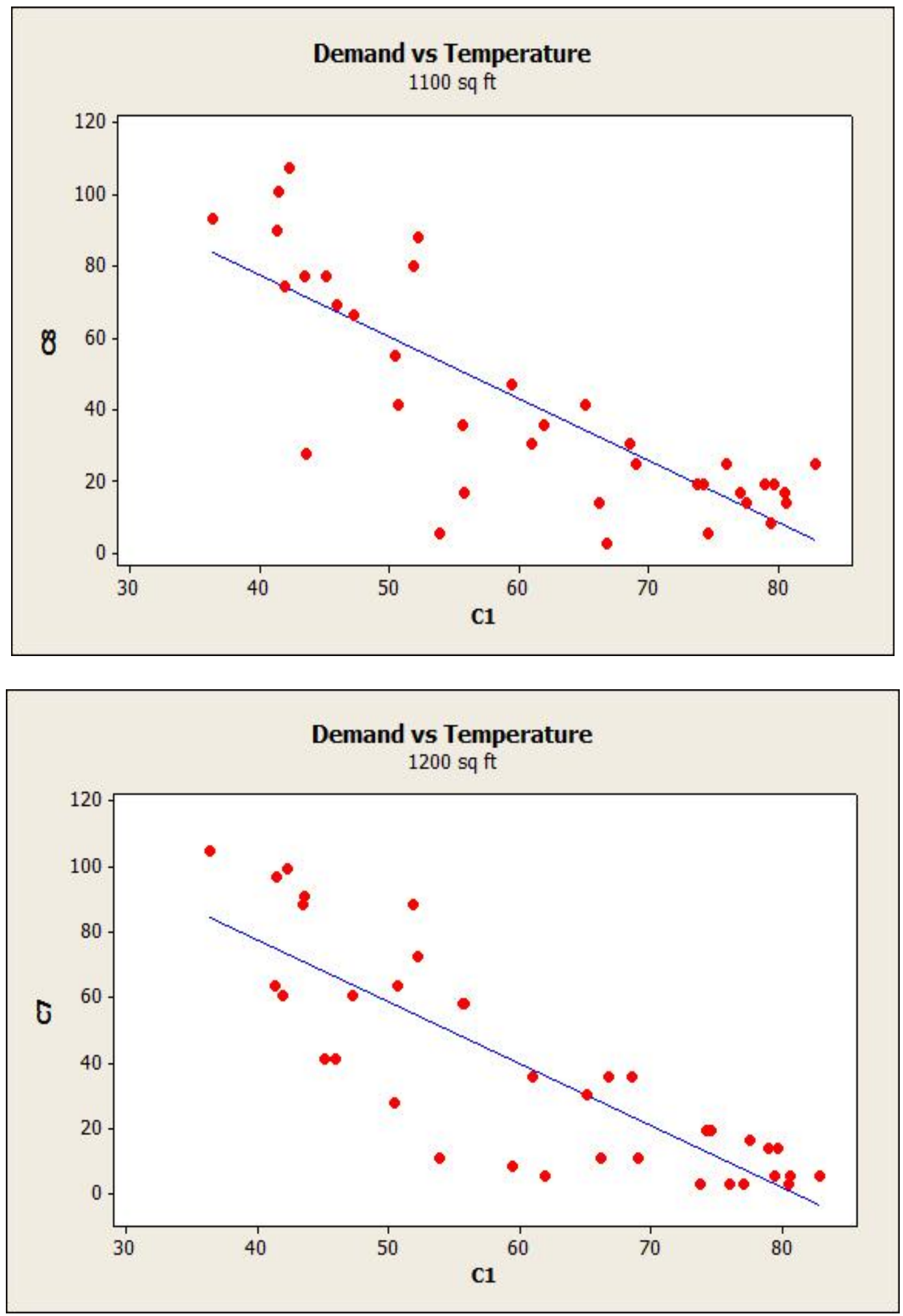
Texas Tech University, Nitin Shenoy, May 2011
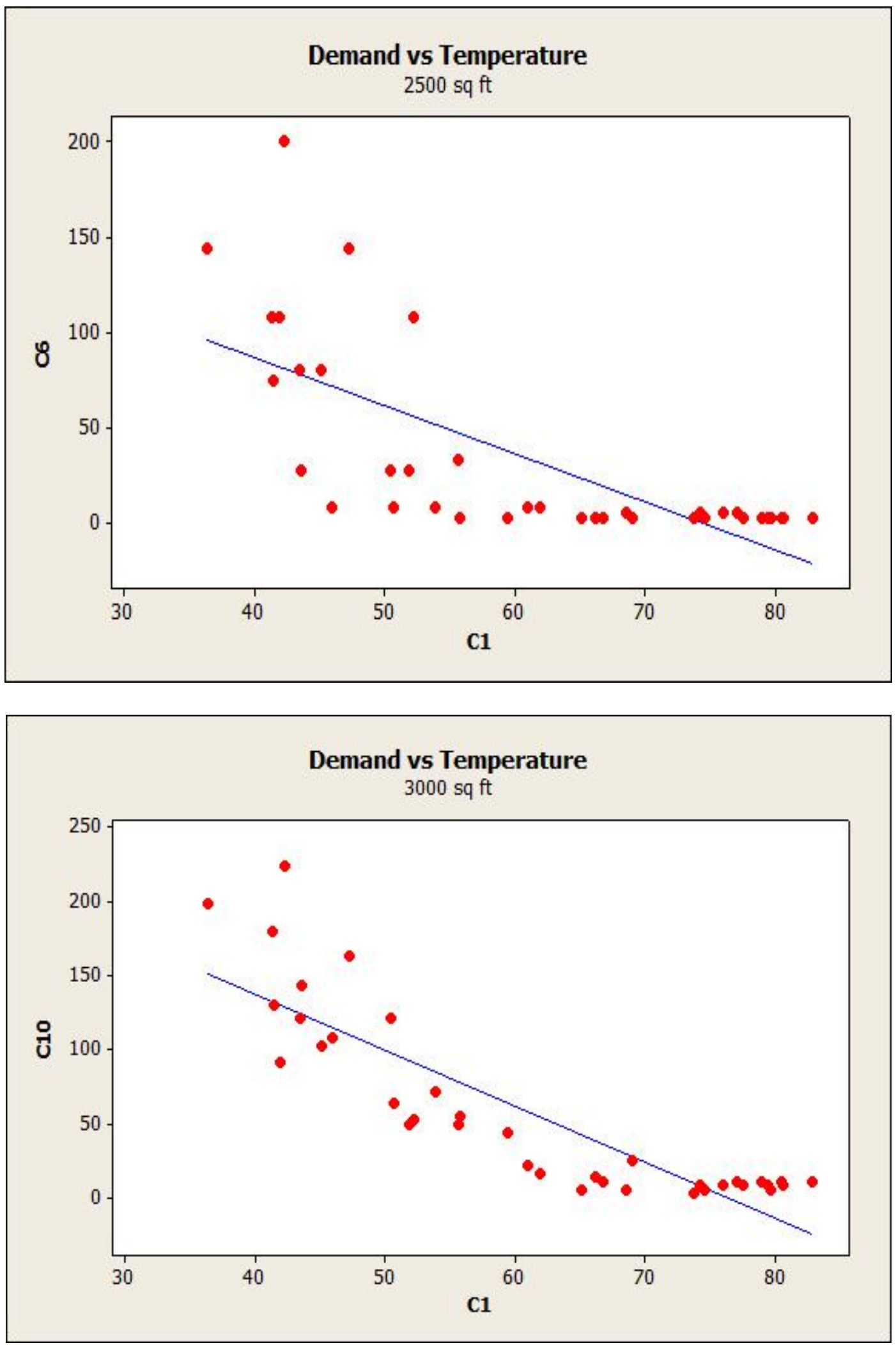
Texas Tech University, Nitin Shenoy, May 2011
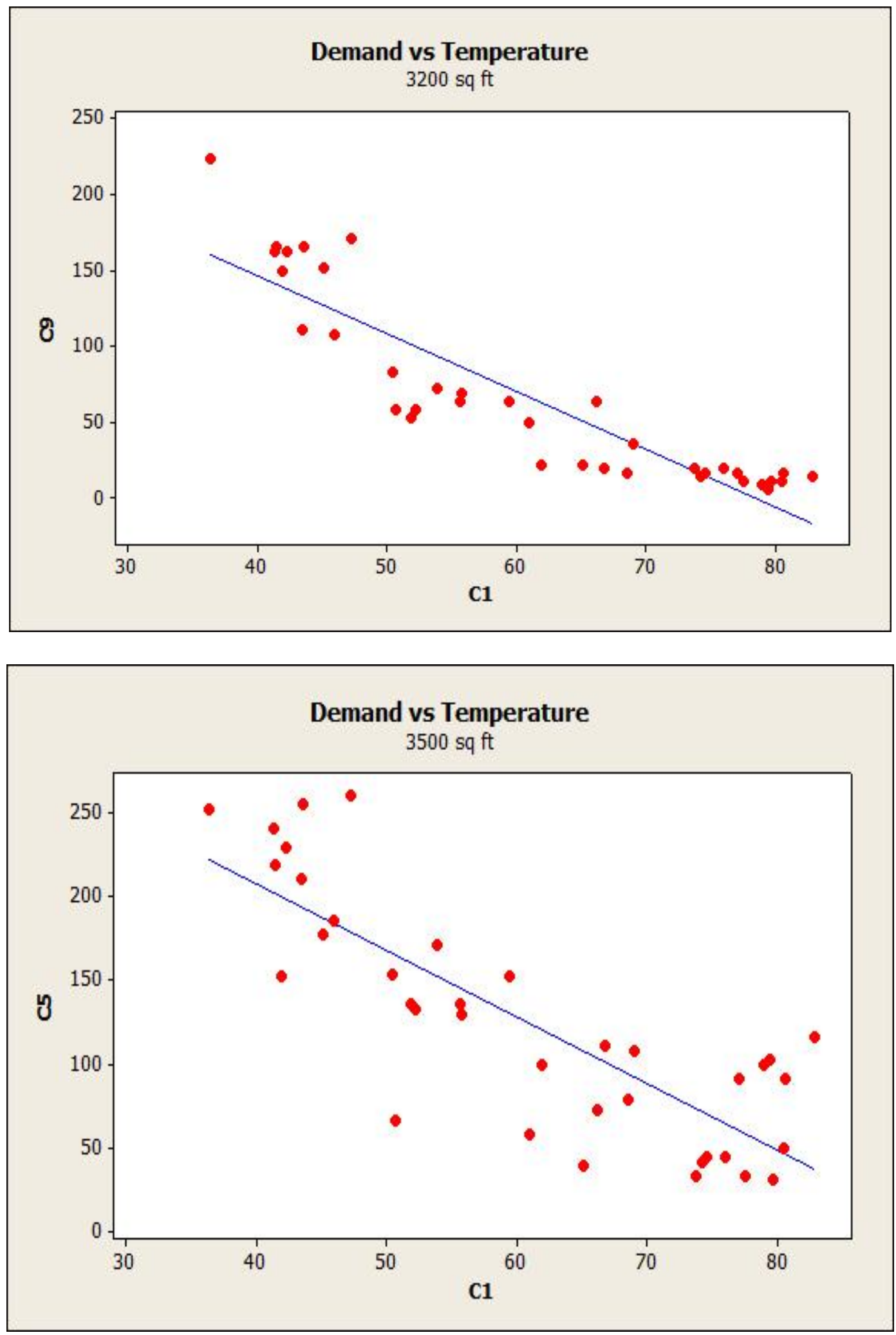
Texas Tech University, Nitin Shenoy, May 2011

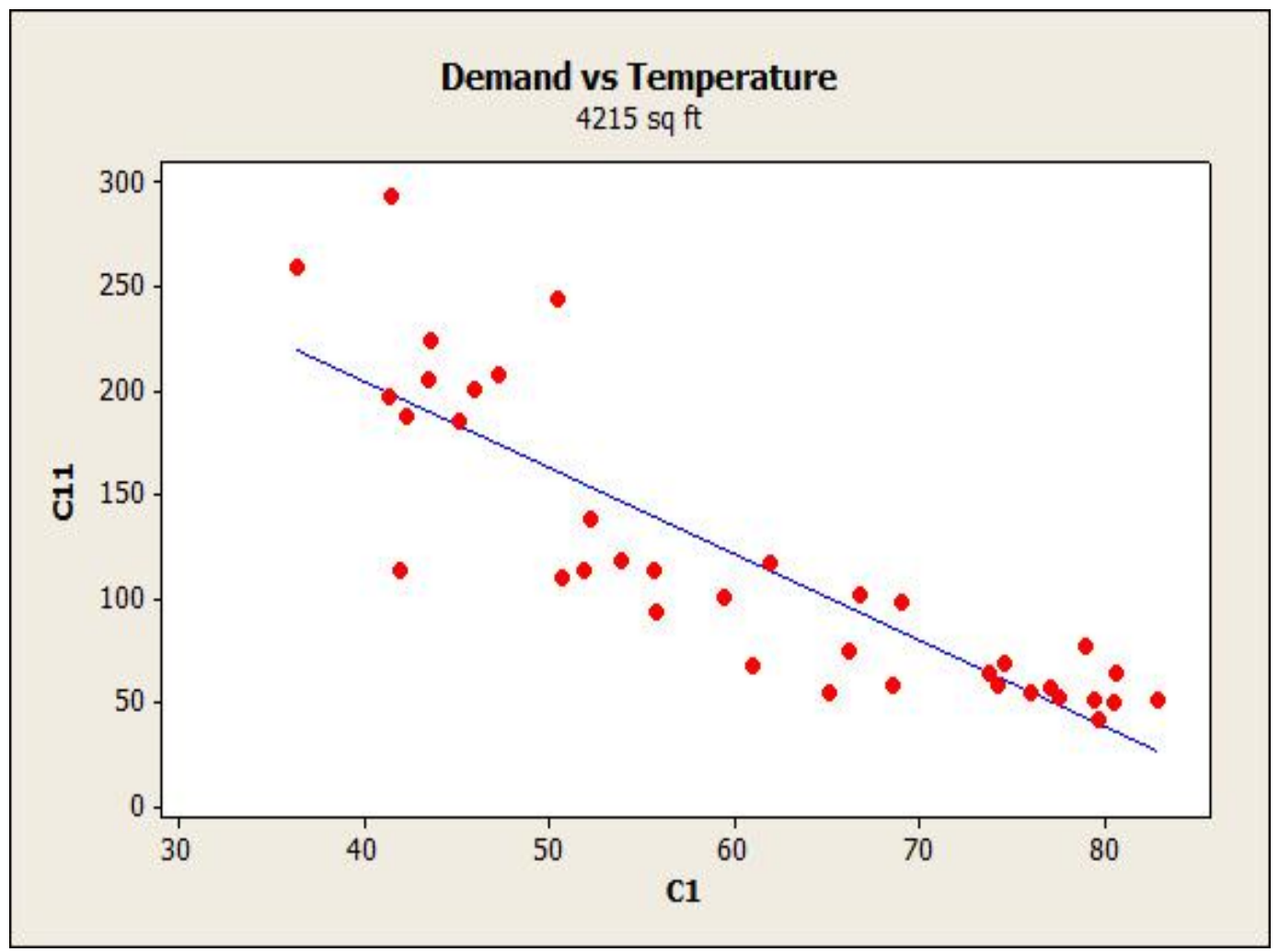




\section{Scatter plots for Demand versus Propane Price}

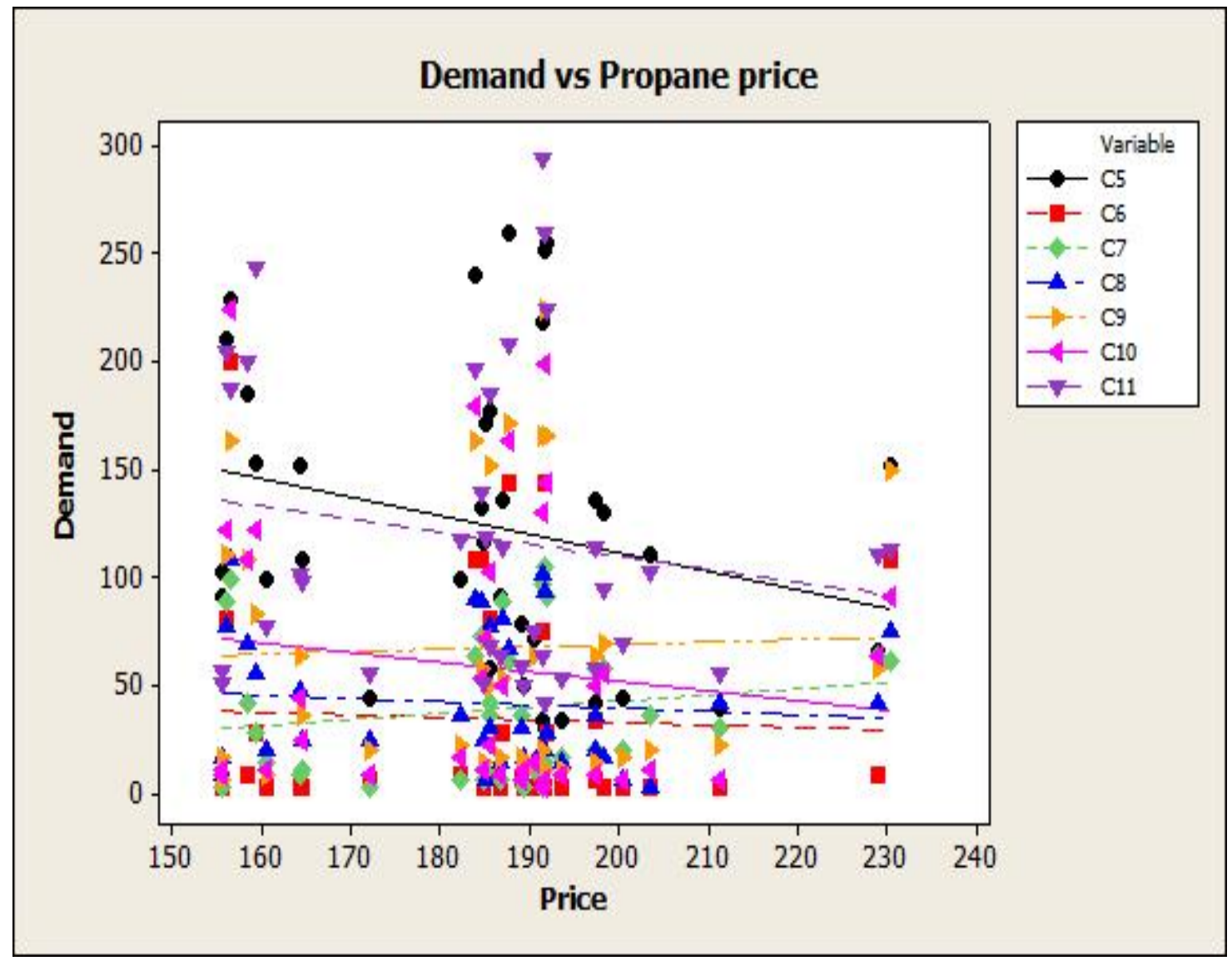


Texas Tech University, Nitin Shenoy, May 2011

\section{APPENDIX C}

\section{MODELS}

\section{Different Models Developed on SAS software for Estimating Propane Demand.}

\section{Model 1}

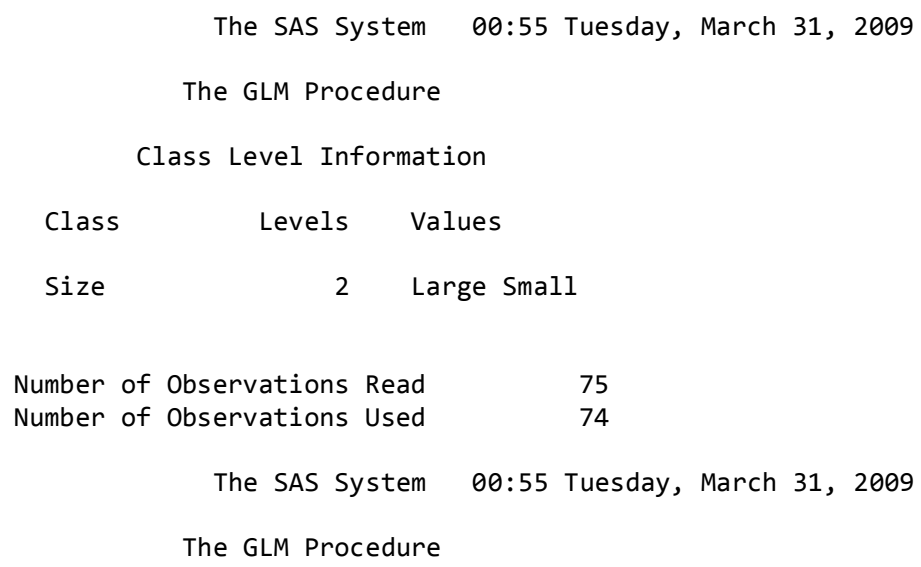

Dependent Variable: Propane_Consumption_4215_sq_ft_

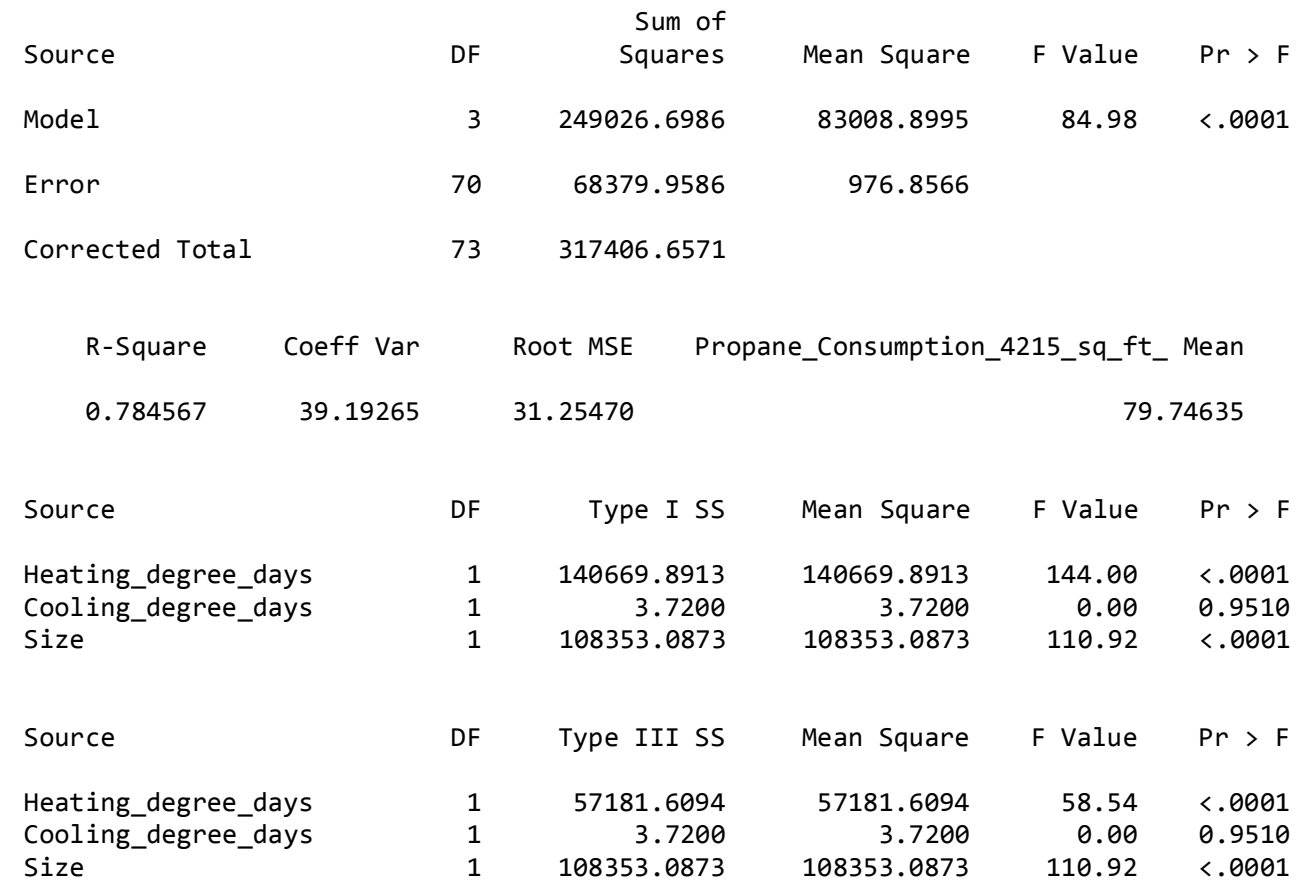

Standard 
Texas Tech University, Nitin Shenoy, May 2011

\begin{tabular}{|c|c|c|c|c|c|}
\hline Parameter & & Estimate & Error & t Value & $\operatorname{Pr}>|t|$ \\
\hline Intercept & & $-1.94558435 B$ & 11.10150242 & -0.18 & 0.8614 \\
\hline Heating_degree_days & & 0.15883425 & 0.02076019 & 7.65 & $<.0001$ \\
\hline Cooling_degree_days & & 0.00190573 & 0.03088211 & 0.06 & 0.9510 \\
\hline Size & Large & $76.53054054 \mathrm{~B}$ & 7.26657119 & 10.53 & $<.0001$ \\
\hline Size & Small & $0.00000000 \mathrm{~B}$ & . & . & . \\
\hline
\end{tabular}

NOTE: The $\mathrm{X}$ 'X matrix has been found to be singular, and a generalized inverse was used to solve the

normal equations. Terms whose estimates are followed by the letter 'B' are not uniquely estimable.

\section{Model 2}

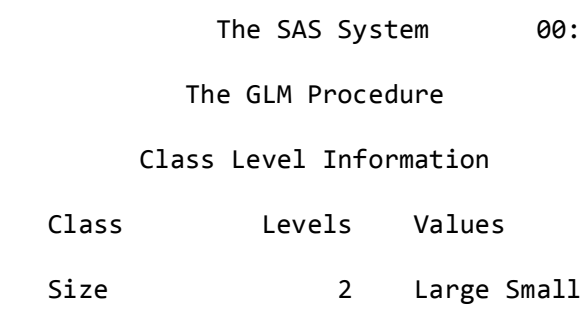

Number of Observations Read

188

Number of Observations Used

74

The SAS system

00:55 Tuesday, March 31, 2009

The GLM Procedure

Dependent Variable: Propane_Consumption_4215_sq_ft_

\begin{tabular}{|c|c|c|c|c|c|}
\hline Source & \multicolumn{5}{|c|}{ Sum of } \\
\hline Model & 4 & 249081.3614 & 62270.3404 & 62.89 & $<.0001$ \\
\hline Error & 69 & 68325.2957 & 990.2217 & & \\
\hline Corrected Total & 73 & 317406.6571 & & & \\
\hline Coeff Var & & Root MSE & e_Consumption & 215_sq_ft_ & Mean \\
\hline 0.784739 & & 31.46779 & & 79. & 74635 \\
\hline Source & DF & Type I SS & Mean Square & F Value & $\mathrm{Pr}>\mathrm{F}$ \\
\hline Temperature & 1 & 129976.7812 & 129976.7812 & 131.26 & $<.0001$ \\
\hline Heating_degree_days & 1 & 10694.0038 & 10694.0038 & 10.80 & 0.0016 \\
\hline Cooling_degree_days & 1 & 57.4892 & 57.4892 & 0.06 & 0.8103 \\
\hline Size & 1 & 108353.0873 & 108353.0873 & 109.42 & $<.0001$ \\
\hline Source & DF & Type III SS & Mean Square & F Value & $\mathrm{Pr}>\mathrm{F}$ \\
\hline Temperature & 1 & 54.6629 & 54.6629 & 0.06 & 0.8149 \\
\hline Heating_degree_days & 1 & 193.9007 & 193.9007 & 0.20 & 0.6595 \\
\hline
\end{tabular}


Texas Tech University, Nitin Shenoy, May 2011

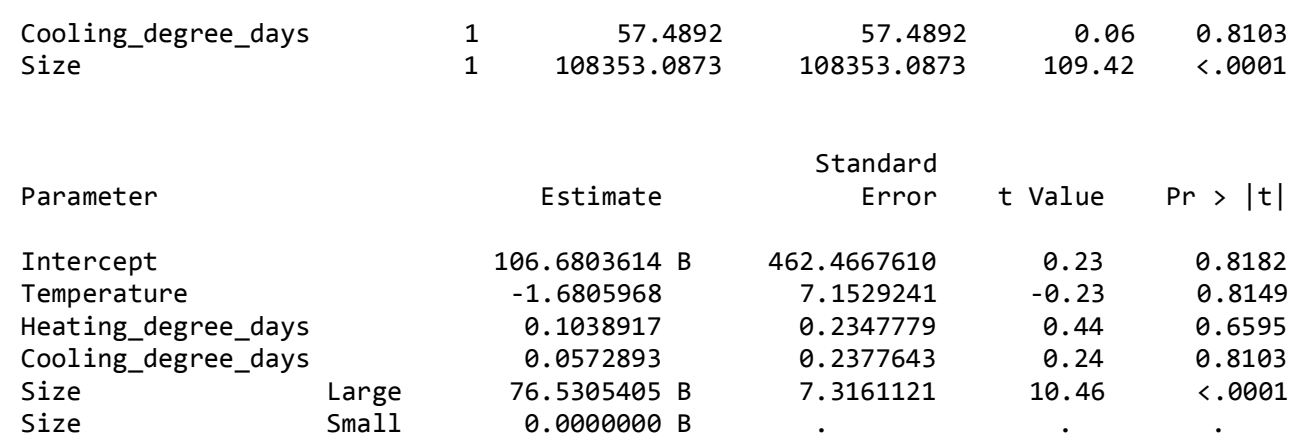

NOTE: The $X^{\prime} X$ matrix has been found to be singular, and a generalized inverse was used to solve the

normal equations. Terms whose estimates are followed by the letter 'B' are not uniquely estimable.

\section{Model 3}

The SAS System 00:55 Tuesday, March 31, 2009

The GLM Procedure

Class Level Information

Class Levels Values

Size $\quad 2 \quad$ Large Small

Number of Observations Read

Number of Observations Used

188

The SAS System

00:55 Tuesday, March 31, 2009

The GLM Procedure

Dependent Variable: Propane_Consumption_4215_sq_ft_

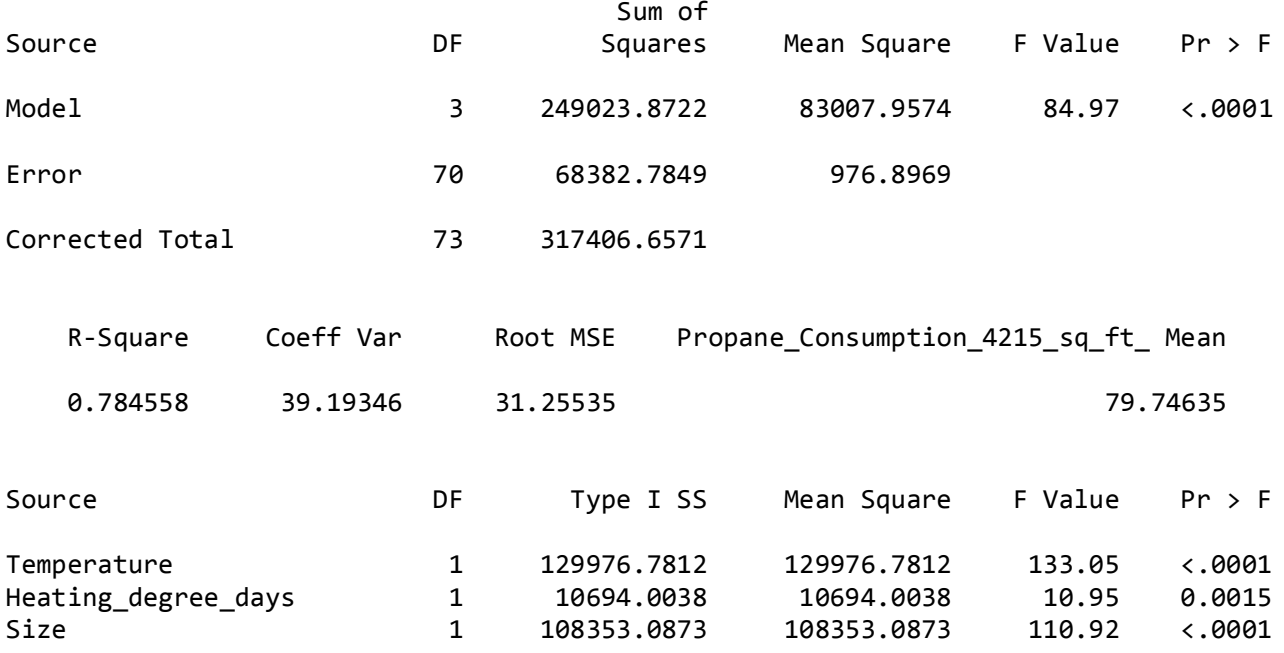


Texas Tech University, Nitin Shenoy, May 2011

\begin{tabular}{|c|c|c|c|c|c|c|c|}
\hline Source & & DF & Type III SS & Mean Square & & F Value & $\mathrm{Pr}>\mathrm{F}$ \\
\hline Temperature & & 1 & 0.8936 & 0.8936 & & 0.00 & 0.9760 \\
\hline Heating_degree_days & & 1 & 10694.0038 & 10694.0038 & & 10.95 & 0.0015 \\
\hline Size & & 1 & 108353.0873 & 108353.0873 & & 110.92 & $<.0001$ \\
\hline Parameter & & & Estimate & $\begin{array}{r}\text { Standard } \\
\text { Error }\end{array}$ & $\mathrm{t}$ & Value & $\operatorname{Pr}>|t|$ \\
\hline Intercept & & & -3.47093396 B & 69.42518651 & & -0.05 & 0.9603 \\
\hline Temperature & & & 0.02809999 & 0.92907938 & & 0.03 & 0.9760 \\
\hline Heating_degree_days & & & 0.15924337 & 0.04812997 & & 3.31 & 0.0015 \\
\hline Size & Large & & $76.53054054 \mathrm{~B}$ & 7.26672136 & & 10.53 & $<.0001$ \\
\hline Size & Small & & $0.00000000 \mathrm{~B}$ & . & & • & . \\
\hline
\end{tabular}

NOTE: The X'X matrix has been found to be singular, and a generalized inverse was used to solve the

normal equations. Terms whose estimates are followed by the letter 'B' are not uniquely estimable.

\section{Model 4}

The SAS System 00:55 Tuesday, March 31, 2009

The GLM Procedure

Class Level Information

Class Levels Values

Size $\quad 2 \quad$ Large Small

Number of Observations Read

188

Number of Observations Used

148

The SAS System

00:55 Tuesday, March 31, 2009

The GLM Procedure

Dependent Variable: Propane_Consumption_4215_sq_ft_

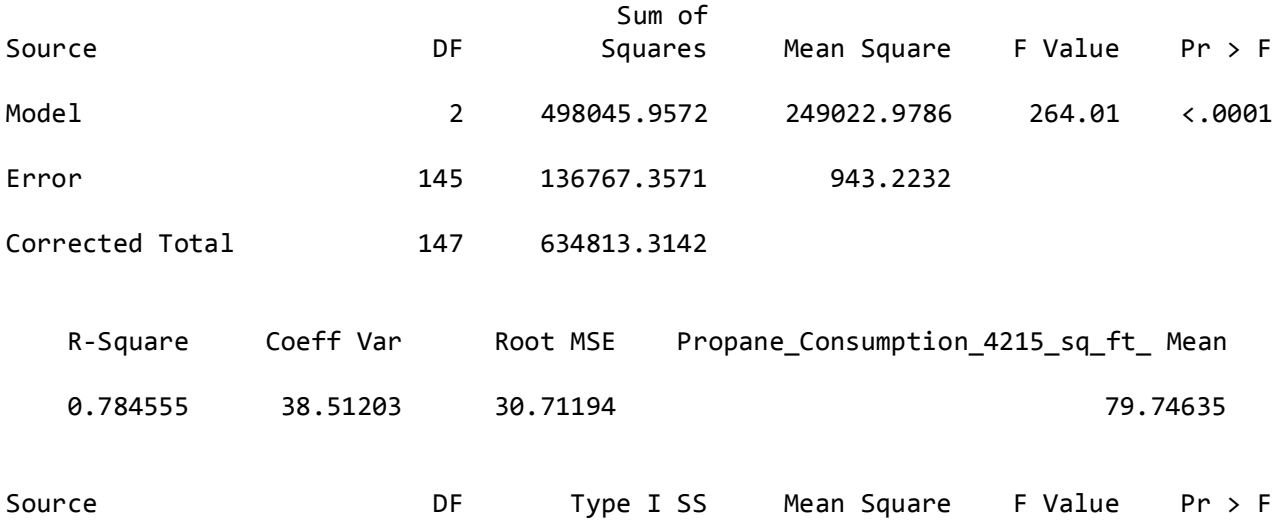


Texas Tech University, Nitin Shenoy, May 2011

\begin{tabular}{|c|c|c|c|c|c|c|c|}
\hline Heating_degree_days & & 1 & 281339.7827 & 281339.7827 & & 298.27 & $<.0001$ \\
\hline Size & & 1 & 216706.1745 & 216706.1745 & & 229.75 & $<.0001$ \\
\hline Source & & DF & Type III SS & Mean Square & & F Value & $\mathrm{Pr}>\mathrm{F}$ \\
\hline Heating_degree_days & & 1 & 281339.7827 & 281339.7827 & & 298.27 & $<.0001$ \\
\hline Size & & 1 & 216706.1745 & 216706.1745 & & 229.75 & $<.0001$ \\
\hline Parameter & & & Estimate & $\begin{array}{r}\text { Standard } \\
\text { Error }\end{array}$ & $t$ & Value & $\operatorname{Pr}>|t|$ \\
\hline Intercept & & & -1.37971808 B & 4.34800741 & & -0.32 & 0.7515 \\
\hline Heating_degree_days & & & 0.15784309 & 0.00913939 & & 17.27 & $<.0001$ \\
\hline Size & Large & & $76.53054054 \mathrm{~B}$ & 5.04901155 & & 15.16 & $<.0001$ \\
\hline Size & Small & & $0.00000000 \mathrm{~B}$ & . & & . & . \\
\hline
\end{tabular}

NOTE: The $X$ 'X matrix has been found to be singular, and a generalized inverse was used to solve the

normal equations. Terms whose estimates are followed by the letter 'B' are not uniquely estimable.

\section{Model 5}

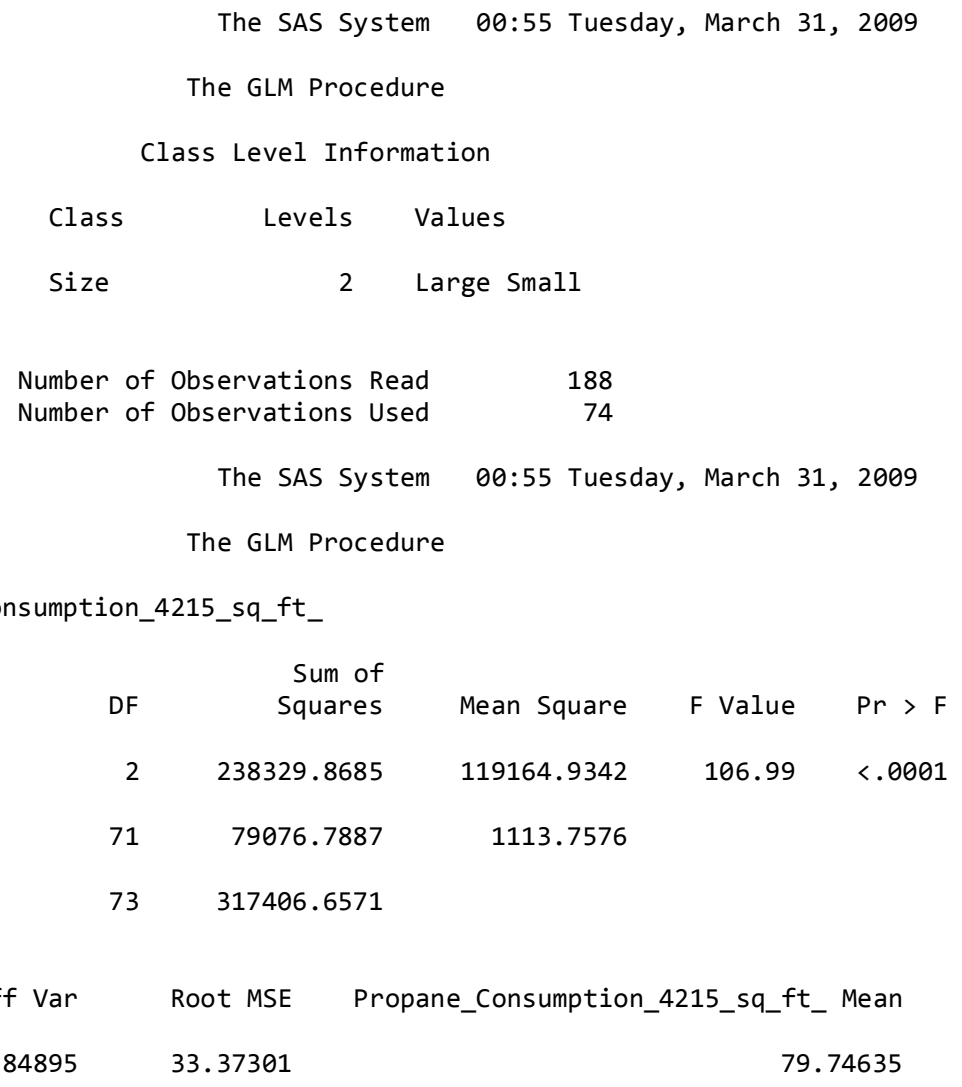


Texas Tech University, Nitin Shenoy, May 2011

\begin{tabular}{|c|c|c|c|c|c|}
\hline Source & DF & Type I SS & Mean Square & F Value & $\mathrm{Pr}>\mathrm{F}$ \\
\hline Temperature & 1 & 129976.7812 & 129976.7812 & 116.70 & $<.0001$ \\
\hline Size & 1 & 108353.0873 & 108353.0873 & 97.29 & $<.0001$ \\
\hline Source & DF & Type III SS & Mean Square & F Value & $\mathrm{Pr}>\mathrm{F}$ \\
\hline Temperature & 1 & 129976.7812 & 129976.7812 & 116.70 & $<.0001$ \\
\hline Size & 1 & 108353.0873 & 108353.0873 & 97.29 & $<.0001$ \\
\hline
\end{tabular}

\begin{tabular}{|c|c|c|c|c|c|c|}
\hline Parameter & & Estimate & & $\begin{array}{c}\text { Standard } \\
\text { Error }\end{array}$ & t Value & $\operatorname{Pr}>|t|$ \\
\hline Intercept & & 219.8155762 & B & 17.39597134 & 12.64 & $<.0001$ \\
\hline Temperature & & -2.9288368 & & 0.27111754 & -10.80 & $<.0001$ \\
\hline Size & Large & 76.5305405 & B & 7.75906649 & 9.86 & $<.0001$ \\
\hline Size & Small & 0.0000000 & B & . & • & • \\
\hline
\end{tabular}

NOTE: The $X ' X$ matrix has been found to be singular, and a generalized inverse was used to solve the

normal equations. Terms whose estimates are followed by the letter 'B' are not uniquely estimable.

\section{Model 6}

The SAS System 00:55 Tuesday, March 31, 2009

The GLM Procedure

Class Level Information

Class Levels Values

Size $\quad 2 \quad$ Large Small

Number of Observations Read 188

Number of Observations Used 148

The SAS System 00:55 Tuesday, March 31, 2009

The GLM Procedure

Dependent Variable: Propane_Consumption_4215_sq_ft_

$\begin{array}{lrrrr}\text { Source } & \text { DF } & \begin{array}{r}\text { Sum of } \\ \text { Squares }\end{array} & \text { Mean Square } & \mathrm{F} \text { Value } \\ \text { Model } & 2 & 383690.1782 & 191845.0891 & 110.77< \\ \text { Error } & 145 & 251123.1360 & 1731.8837 & <001 \\ \text { Corrected Total } & 147 & 634813.3142 & \end{array}$

$\begin{array}{lrrr}\text { R-Square } & \text { Coeff Var } & \text { Root MSE } & \text { Propane_Consumption_4215_sq_ft_ Mean } \\ 0.604414 & 52.18534 & 41.61591 & 79.74635\end{array}$


Texas Tech University, Nitin Shenoy, May 2011

\begin{tabular}{|c|c|c|c|c|c|c|c|}
\hline Source & & DF & Type I SS & Mean Square & & F Value & $\mathrm{Pr}>\mathrm{F}$ \\
\hline Cooling_degree_days & & 1 & 166984.0037 & 166984.0037 & & 96.42 & $<.0001$ \\
\hline Size & & 1 & 216706.1745 & 216706.1745 & & 125.13 & $<.0001$ \\
\hline Source & & DF & Type III sS & Mean Square & & F Value & $\mathrm{Pr}>\mathrm{F}$ \\
\hline Cooling_degree_days & & 1 & 166984.0037 & 166984.0037 & & 96.42 & $<.0001$ \\
\hline Size & & 1 & 216706.1745 & 216706.1745 & & 125.13 & $<.0001$ \\
\hline Parameter & & & Estimate & $\begin{array}{r}\text { Standard } \\
\text { Error }\end{array}$ & $t$ & Value & $\operatorname{Pr}>|t|$ \\
\hline Intercept & & & 69.64669006 B & 5.62419806 & & 12.38 & $<.0001$ \\
\hline Cooling_degree_days & & & -0.18089351 & 0.01842235 & & -9.82 & $<.0001$ \\
\hline Size & Large & & $76.53054054 \mathrm{~B}$ & 6.84161293 & & 11.19 & $<.0001$ \\
\hline Size & Small & & 0.00000000 B & . & & . & . \\
\hline
\end{tabular}

NOTE: The $X$ 'X matrix has been found to be singular, and a generalized inverse was used to solve the

normal equations. Terms whose estimates are followed by the letter 'B' are not uniquely estimable.

\section{Model 7}

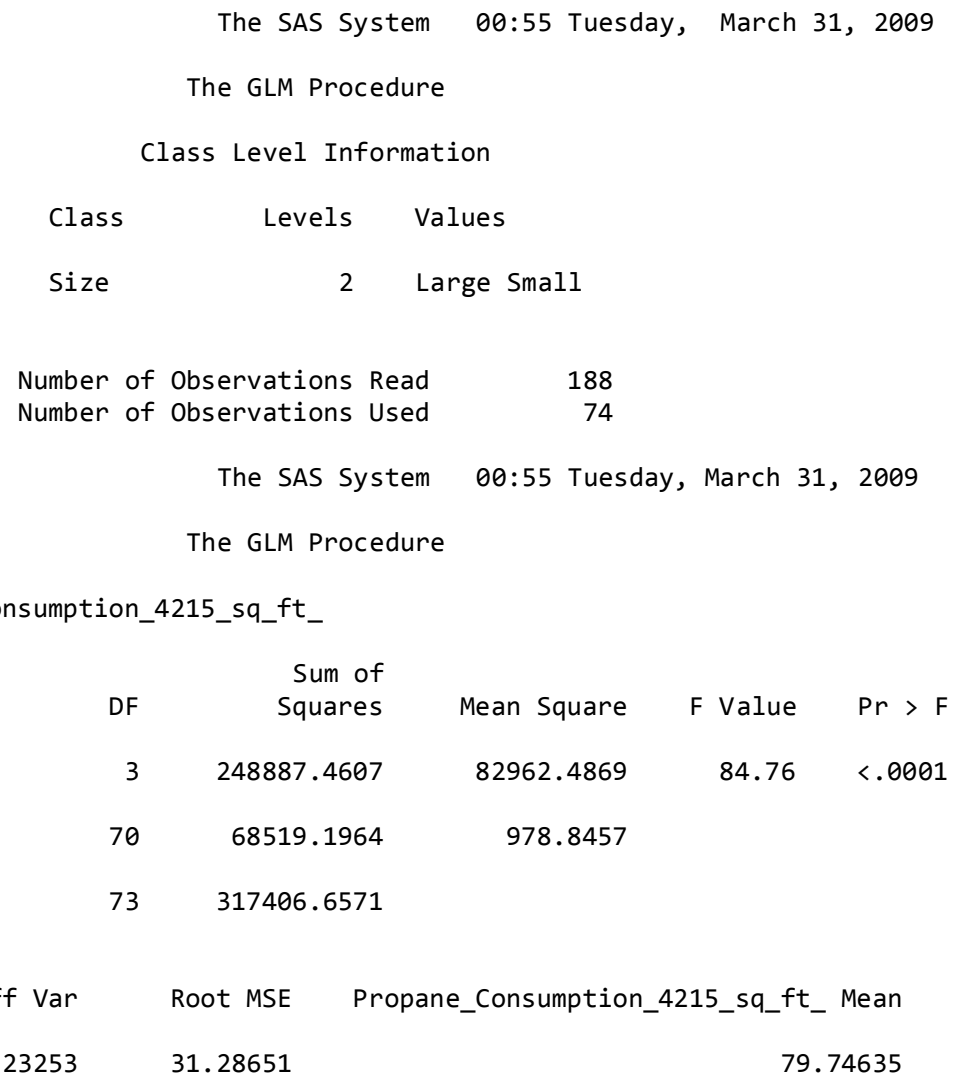


Texas Tech University, Nitin Shenoy, May 2011

\begin{tabular}{|c|c|c|c|c|c|c|c|}
\hline Source & & DF & Type I SS & Mean Square & & F Value & $\mathrm{Pr}>\mathrm{F}$ \\
\hline Temperature & & 1 & 129976.7812 & 129976.7812 & & 132.79 & $<.0001$ \\
\hline Cooling_degree_days & & 1 & 10557.5922 & 10557.5922 & & 10.79 & 0.0016 \\
\hline Size & & 1 & 108353.0873 & 108353.0873 & & 110.69 & $<.0001$ \\
\hline Source & & DF & Type III SS & Mean Square & & F Value & $\mathrm{Pr}>\mathrm{F}$ \\
\hline Temperature & & 1 & 57042.3716 & 57042.3716 & & 58.28 & $<.0001$ \\
\hline Cooling_degree_days & & 1 & 10557.5922 & 10557.5922 & & 10.79 & 0.0016 \\
\hline Size & & 1 & 108353.0873 & 108353.0873 & & 110.69 & $<.0001$ \\
\hline Parameter & & & Estimate & $\begin{array}{r}\text { Standard } \\
\text { Error }\end{array}$ & $\mathrm{t}$ & Value & $\operatorname{Pr}>|t|$ \\
\hline Intercept & & & 310.8257108 B & 32.15440198 & & 9.67 & $<.0001$ \\
\hline Temperature & & & -4.8332715 & 0.63313965 & & -7.63 & $<.0001$ \\
\hline Cooling_degree_days & & & 0.1602371 & 0.04879078 & & 3.28 & 0.0016 \\
\hline Size & Large & & 76.5305405 B & 7.27396566 & & 10.52 & $<.0001$ \\
\hline Size & Small & & $0.0000000 \mathrm{~B}$ & . & & . & . \\
\hline
\end{tabular}

NOTE: The X'X matrix has been found to be singular, and a generalized inverse was used to solve the

normal equations. Terms whose estimates are followed by the letter 'B' are not uniquely estimable.

\section{Model 8}

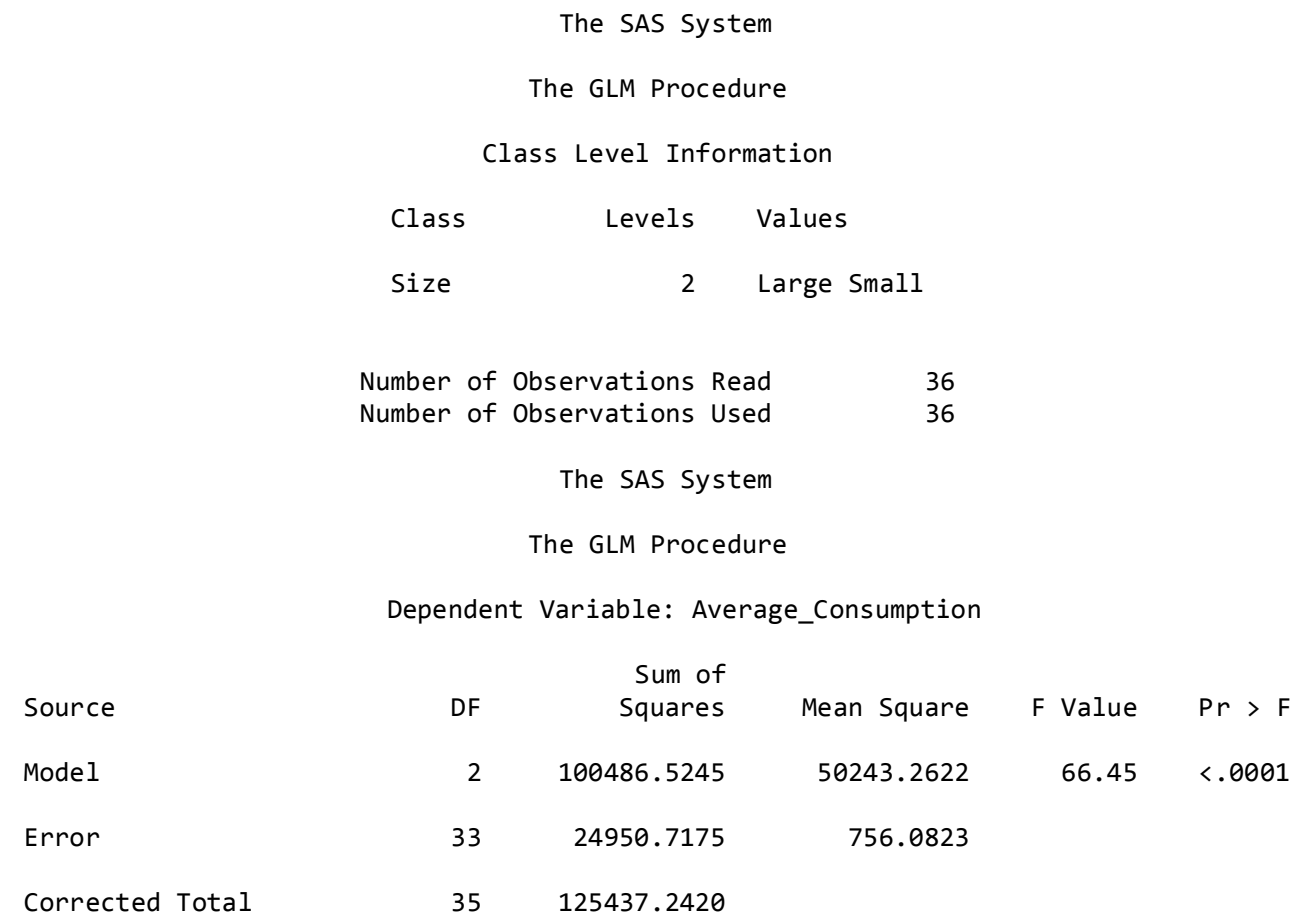


Texas Tech University, Nitin Shenoy, May 2011

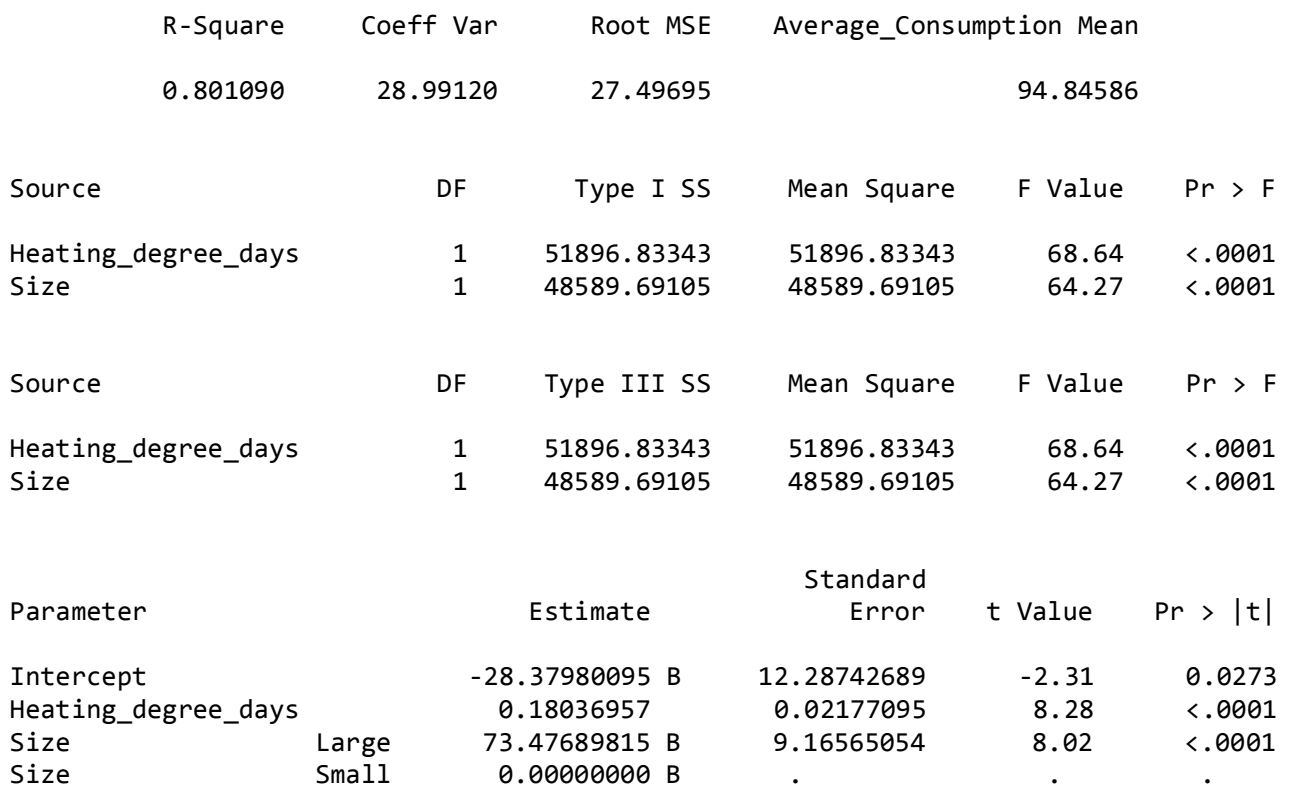

NOTE: The X'X matrix has been found to be singular, and a generalized inverse was used to solve the

normal equations. Terms whose estimates are followed by the letter 'B' are not uniquely estimable.

\section{Model 9}

The SAS System

The GLM Procedure

Class Level Information

$\begin{array}{lrl}\text { Class } & \text { Levels } & \text { Values } \\ \text { Size } & 2 & \text { Large Small }\end{array}$

Number of Observations Read

The SAS System

The GLM Procedure

Dependent Variable: Average_Consumption

Source

Model

Error

Corrected Total

$\begin{array}{rrrrr}\text { Squm of } & \begin{array}{r}\text { Sumes } \\ \text { Squares }\end{array} & \text { Mean Square } & \text { F Value } & \text { Pr }>\text { F } \\ 2 & 99425.3432 & 49712.6716 & 63.07 & <.0001 \\ 33 & 26011.8987 & 788.2394 & & \\ 35 & 125437.2420 & & \end{array}$


Texas Tech University, Nitin Shenoy, May 2011

\begin{tabular}{|c|c|c|c|c|c|}
\hline R-Square & Coeff Var & Root MSE & \multicolumn{2}{|c|}{ Average_Consumption Mean } & \\
\hline 0.792630 & 29.60129 & 28.07560 & & 94.84586 & \\
\hline Source & DF & Type I SS & Mean Square & F Value & $\mathrm{Pr}>\mathrm{F}$ \\
\hline Temperature & 1 & 50835.65216 & 50835.65216 & 64.49 & $<.0001$ \\
\hline Size & 1 & 48589.69105 & 48589.69105 & 61.64 & $<.0001$ \\
\hline Source & DF & Type III SS & Mean Square & F Value & $\mathrm{Pr}>\mathrm{F}$ \\
\hline Temperature & 1 & 50835.65216 & 50835.65216 & 64.49 & $<.0001$ \\
\hline Size & 1 & 48589.69105 & 48589.69105 & 61.64 & $<.0001$ \\
\hline
\end{tabular}

\begin{tabular}{|c|c|c|c|c|c|}
\hline Parameter & & Estimate & $\begin{array}{r}\text { Standard } \\
\text { Error }\end{array}$ & t Value & $\operatorname{Pr}>|t|$ \\
\hline Intercept & & 299.1229523 & 30.73256210 & 9.73 & $<.0001$ \\
\hline Temperature & & -4.8766635 & 0.60725017 & -8.03 & $<.0001$ \\
\hline Size & Large & 73.4768981 & 9.35853357 & 7.85 & $<.0001$ \\
\hline Size & Small & 0.0000000 & . & . & . \\
\hline
\end{tabular}

NOTE: The X'X matrix has been found to be singular, and a generalized inverse was used to solve the

normal equations. Terms whose estimates are followed by the letter 'B' are not uniquely estimable.

\section{Model for the Month of October- November}

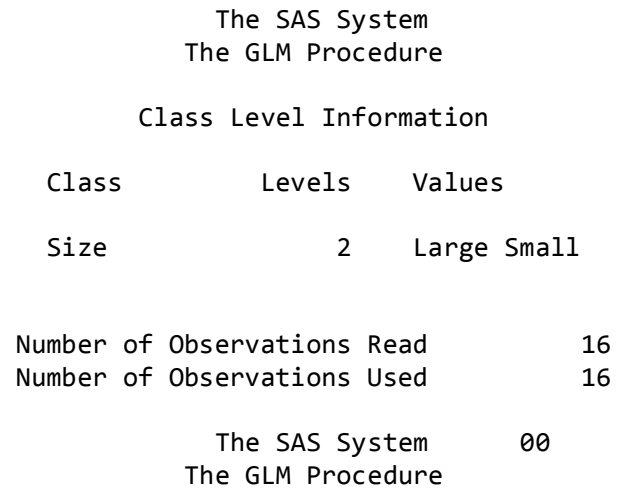

Dependent Variable: Average_consumption

\begin{tabular}{|c|c|c|c|c|c|}
\hline Source & DF & $\begin{array}{l}\text { Sum of } \\
\text { Squares }\end{array}$ & Mean Square & F Value & $\mathrm{Pr}>\mathrm{F}$ \\
\hline Model & 2 & 4197.891223 & 2098.945612 & 5.44 & 0.0192 \\
\hline Error & 13 & 5014.570336 & 385.736180 & & \\
\hline Corrected Total & 15 & 9212.461560 & & & \\
\hline
\end{tabular}


Texas Tech University, Nitin Shenoy, May 2011

\begin{tabular}{|c|c|c|c|c|c|}
\hline R-Square & Coeff Var & Root MSE & \multicolumn{2}{|c|}{ Average_consumption Mean } & \\
\hline 0.455675 & 38.89934 & 19.64017 & & 50.48972 & \\
\hline Source & DF & Type I SS & Mean Square & F Value & $\mathrm{Pr}>\mathrm{F}$ \\
\hline Temperature & 1 & 2813.472496 & 2813.472496 & 7.29 & 0.0182 \\
\hline Size & 1 & 1384.418728 & 1384.418728 & 3.59 & 0.0806 \\
\hline Source & DF & Type III sS & Mean Square & F Value & $\mathrm{Pr}>\mathrm{F}$ \\
\hline Temperature & 1 & 2813.472496 & 2813.472496 & 7.29 & 0.0182 \\
\hline Size & 1 & 1384.418728 & 1384.418728 & 3.59 & 0.0806 \\
\hline
\end{tabular}

\begin{tabular}{|c|c|c|c|c|c|c|}
\hline Parameter & & Estimate & & $\begin{array}{r}\text { Standard } \\
\text { Error }\end{array}$ & t Value & $\operatorname{Pr}>|t|$ \\
\hline Intercept & & 176.8193594 & B & 50.69869794 & 3.49 & 0.0040 \\
\hline Temperature & & -2.3836833 & & 0.88261725 & -2.70 & 0.0182 \\
\hline Size & Large & 18.6038889 & B & 9.82008375 & 1.89 & 0.0806 \\
\hline Size & Small & 0.0000000 & B & . & . & . \\
\hline
\end{tabular}

NOTE: The X'X matrix has been found to be singular, and a generalized inverse was used to solve the

normal equations. Terms whose estimates are followed by the letter 'B' are not uniquely estimable.

\section{Model for the Month of December-January}

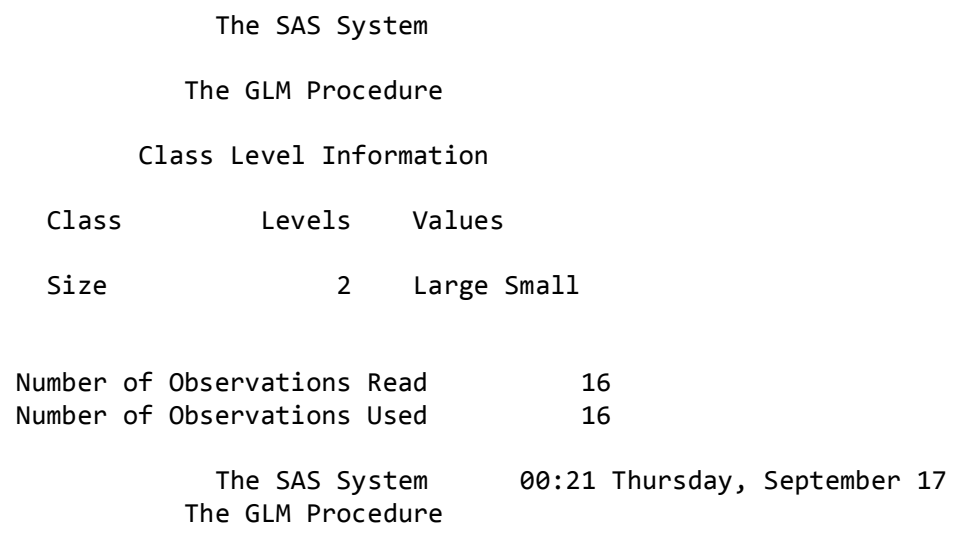

Dependent Variable: Average_consumption

\begin{tabular}{|c|c|c|c|c|c|}
\hline Source & DF & $\begin{array}{l}\text { Sum of } \\
\text { Squares }\end{array}$ & Mean Square & F Value & $\mathrm{Pr}>\mathrm{F}$ \\
\hline Model & 2 & 17886.67872 & 8943.33936 & 15.25 & 0.0004 \\
\hline Error & 13 & 7625.26712 & 586.55901 & & \\
\hline Corrected Total & 15 & 25511.94585 & & & \\
\hline
\end{tabular}


Texas Tech University, Nitin Shenoy, May 2011

\begin{tabular}{|c|c|c|c|c|c|}
\hline R-Square & Coeff Var & Root MSE & \multicolumn{2}{|c|}{ Average_consumption Mean } & \\
\hline 0.701110 & 17.25101 & 24.21898 & & 140.3917 & \\
\hline Source & DF & Type I SS & Mean Square & F Value & $\mathrm{Pr}>\mathrm{F}$ \\
\hline Temperature & 1 & 4184.02532 & 4184.02532 & 7.13 & 0.0192 \\
\hline Size & 1 & 13702.65341 & 13702.65341 & 23.36 & 0.0003 \\
\hline Source & DF & Type III sS & Mean Square & F Value & $\mathrm{Pr}>\mathrm{F}$ \\
\hline Temperature & 1 & 4184.02532 & 4184.02532 & 7.13 & 0.0192 \\
\hline Size & 1 & 13702.65341 & 13702.65341 & 23.36 & 0.0003 \\
\hline
\end{tabular}

\begin{tabular}{|c|c|c|c|c|c|c|}
\hline Parameter & & Estimate & & $\begin{array}{r}\text { Standard } \\
\text { Error }\end{array}$ & t Value & $\operatorname{Pr}>|t|$ \\
\hline Intercept & & 349.5044962 & B & 89.66300198 & 3.90 & 0.0018 \\
\hline Temperature & & -5.6959955 & & 2.13269300 & -2.67 & 0.0192 \\
\hline Size & Large & 58.5291667 & B & 12.10949018 & 4.83 & 0.0003 \\
\hline Size & Small & 0.0000000 & B & • & • & . \\
\hline
\end{tabular}

NOTE: The X'X matrix has been found to be singular, and a generalized inverse was used to solve the

normal equations. Terms whose estimates are followed by the letter 'B' are not uniquely estimable.

\section{Model for the Month of February- March}

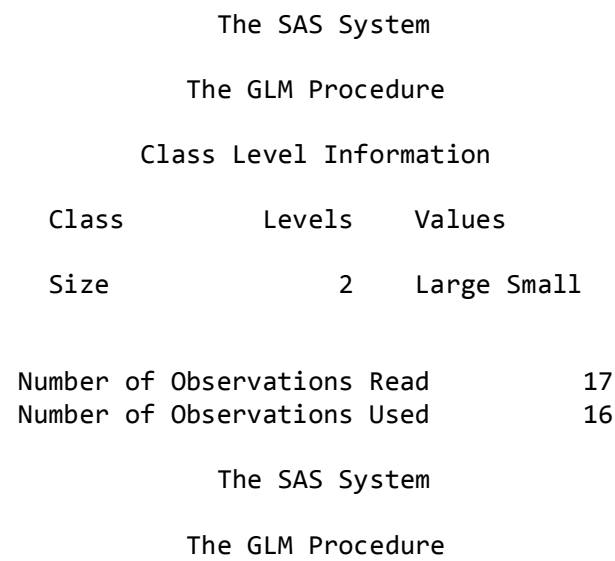

Dependent Variable: Average_consumption

\begin{tabular}{|c|c|c|c|c|c|}
\hline Source & DF & $\begin{array}{l}\text { Sum of } \\
\text { Squares }\end{array}$ & Mean Square & F Value & $\mathrm{Pr}>\mathrm{F}$ \\
\hline Model & 2 & 16283.02767 & 8141.51383 & 16.98 & 0.0002 \\
\hline Error & 13 & 6232.28086 & 479.40622 & & \\
\hline Corrected Total & 15 & 22515.30853 & & & \\
\hline
\end{tabular}


Texas Tech University, Nitin Shenoy, May 2011

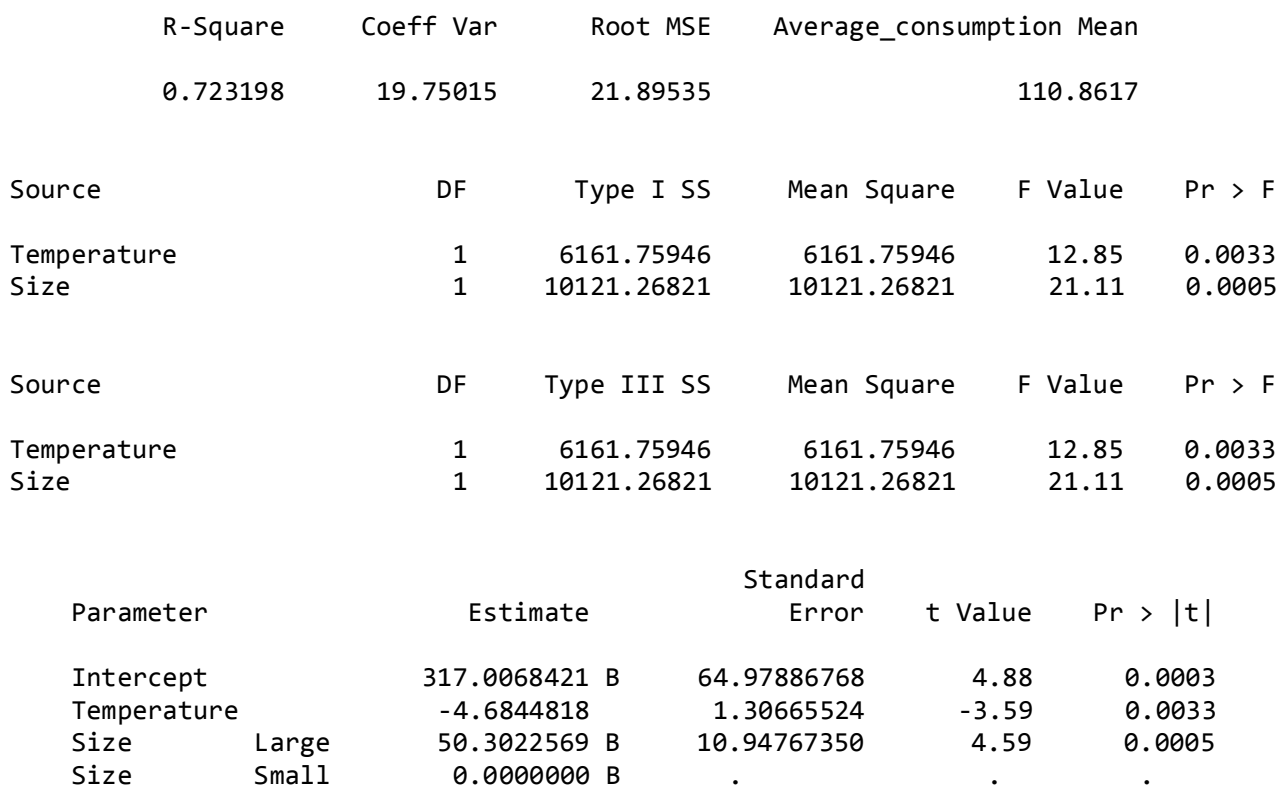

NOTE: The X'X matrix has been found to be singular, and a generalized inverse was used to solve the

normal equations. Terms whose estimates are followed by the letter 'B' are not uniquely estimable. 


\section{APPENDIX D}

\section{Forecasting Performance Charts}

\section{1) Forecasting Performance Chart for Large Houses}

\begin{tabular}{|c|c|c|c|c|}
\hline $\begin{array}{l}\text { Month- } \\
\text { Year }\end{array}$ & $\begin{array}{l}\text { Actual Demand } \\
\left(A_{T}\right) \text { (gallons/month) }\end{array}$ & $\begin{array}{l}\text { Forecasted } \\
\text { Demand }\left(F_{\mathrm{T}}\right)\end{array}$ & Error $\left(E_{T}\right)$ & $\begin{array}{l}\% \mathrm{E} \text { (in } \\
\%)\end{array}$ \\
\hline Dec-04 & 173.21 & 154.4302374 & 18.78143 & 10.84305 \\
\hline Jan-05 & 144.64 & 145.1113716 & -0.4697 & -0.32474 \\
\hline Feb-05 & 143.70 & 127.44238 & 16.26095 & 11.31564 \\
\hline Mar-05 & 135.84 & 118.6817716 & 17.1599 & 12.63228 \\
\hline Apr-05 & 104.32 & 69.08854667 & 35.23312 & 33.77354 \\
\hline May-05 & 46.52 & 108.2271019 & -61.7079 & -132.651 \\
\hline Jun-05 & 29.03 & 187.70576 & -158.678 & -546.648 \\
\hline Jul-05 & 14.14 & 127.0395174 & -112.899 & -798.388 \\
\hline Aug-05 & 27.60 & 117.0280142 & -89.4263 & -323.989 \\
\hline Sep-05 & 73.37 & 80.57338667 & -7.20005 & -9.8129 \\
\hline Oct-05 & 35.75 & 50.56741419 & -14.8149 & -41.4374 \\
\hline Nov-05 & 113.86 & 94.19926667 & 19.6624 & 17.26867 \\
\hline Dec-05 & 174.36 & 153.2957161 & 21.06345 & 12.0805 \\
\hline Jan-06 & 184.21 & 198.2802968 & -14.067 & -7.63624 \\
\hline Feb-06 & 134.27 & 153.60482 & -19.3348 & -14.4 \\
\hline Mar-06 & 111.26 & 99.96639613 & 11.2936 & 10.15064 \\
\hline Apr-06 & 33.29 & 59.85708 & -26.5712 & -79.8275 \\
\hline May-06 & 41.21 & 115.9596581 & -74.7505 & -181.393 \\
\hline Jun-06 & 10.60 & 168.7009467 & -158.097 & -1490.89 \\
\hline Jul-06 & 24.78 & 159.9386413 & -135.163 & -545.543 \\
\hline Aug-06 & 88.52 & 112.1638916 & -23.6414 & -26.7066 \\
\hline Sep-06 & 36.18 & 105.5650133 & -69.39 & -191.818 \\
\hline Oct-06 & 60.73 & 49.97230323 & 10.75686 & 17.71285 \\
\hline Nov-06 & 79.36 & 102.2869067 & -22.9302 & -28.8952 \\
\hline Dec-06 & 162.59 & 157.3308658 & 5.263301 & 3.237079 \\
\hline Jan-07 & 238.03 & 154.0723574 & 83.95764 & 35.27187 \\
\hline Feb-07 & 199.96 & 170.39394 & 29.56939 & 14.78741 \\
\hline Mar-07 & 94.02 & 145.0944697 & -51.0753 & -54.3244 \\
\hline Apr-07 & 87.20 & 122.19092 & -34.9909 & -40.1272 \\
\hline
\end{tabular}


Texas Tech University, Nitin Shenoy, May 2011

\begin{tabular}{|c|c|r|r|r|}
\hline May-07 & 33.20 & 66.93327097 & -33.7333 & -101.606 \\
\hline Jun-07 & 19.83 & 102.05796 & -82.2246 & -414.578 \\
\hline Jul-07 & 8.97 & 138.6333471 & -129.663 & -1445.52 \\
\hline Aug-07 & 15.93 & 124.6308374 & -108.705 & -682.57 \\
\hline Sep-07 & 62.33 & 124.8971333 & -62.5671 & -100.38 \\
\hline Oct-07 & 17.35 & 86.04179097 & -68.6918 & -395.918 \\
\hline Nov-07 & 66.86 & 42.64933333 & 24.214 & 36.21417 \\
\hline Dec-07 & 120.98 & 94.79372774 & 26.18961 & 21.64728 \\
\hline Jan-08 & 159.22 & 166.9143961 & -7.69773 & -4.83475 \\
\hline Feb-08 & 140.27 & 218.13418 & -77.8608 & -55.5065 \\
\hline Mar-08 & 128.77 & 157.7559806 & -28.9843 & -22.5083 \\
\hline Apr-08 & 60.79 & 99.58681333 & -38.796 & -63.8188 \\
\hline May-08 & 33.08 & 69.94722194 & -36.8631 & -111.422 \\
\hline Jun-08 & 19.18 & 133.0151067 & -113.835 & -593.509 \\
\hline Jul-08 & 8.97 & 156.31928 & -147.349 & -1642.69 \\
\hline Aug-08 & 9.43 & 158.2274813 & -148.797 & -1577.92 \\
\hline Sep-08 & 52.10 & 129.2274667 & -77.1275 & -148.037 \\
\hline Oct-08 & 38.80 & 100.0197316 & -61.2197 & -157.783 \\
\hline Nov-08 & 65.62 & 40.33412 & 25.28588 & 38.5338 \\
\hline Dec-08 & 138.01 & 101.4179561 & 36.58871 & 26.51228 \\
\hline
\end{tabular}

2) Forecasting Performance Chart for Small Houses (Dec-Oct)

\begin{tabular}{|c|c|r|r|l|}
\hline $\begin{array}{c}\text { Month- } \\
\text { Year }\end{array}$ & $\begin{array}{l}\text { Actual Demand } \\
\left(\mathrm{A}_{\mathrm{T}}\right) \text { (gallons/month) }\end{array}$ & $\begin{array}{l}\text { Forecasted } \\
\text { Demand }\left(\mathrm{F}_{\mathrm{T}}\right)\end{array}$ & $\begin{array}{l}\text { Error }\left(\mathrm{E}_{\mathrm{T}}\right) \\
\text { (in }\end{array}$ \\
\hline Dec-04 & 90.52 & 113.9892374 & -23.4723 & -25.9314 \\
\hline Jan-05 & 110.87 & 104.6703716 & 6.200398 & 5.592455 \\
\hline Feb-05 & 73.67 & 87.00138 & -13.3306 & -18.0948 \\
\hline Mar-05 & 55.80 & 78.24077161 & -22.4438 & -40.2242 \\
\hline Oct-05 & 44.64 & 10.12641419 & 34.50897 & 77.31303 \\
\hline Nov-05 & 44.41 & 53.75826667 & -9.34596 & -21.0436 \\
\hline Dec-05 & 92.43 & 112.8547161 & -20.4239 & -22.0965 \\
\hline Jan-06 & 64.26 & 157.8392968 & -93.5747 & -145.608 \\
\hline Feb-06 & 75.33 & 113.16382 & -37.8346 & -50.2256 \\
\hline Mar-06 & 47.09 & 59.52539613 & -12.4331 & -26.4015 \\
\hline Oct-06 & 39.03 & 9.531303226 & 29.49639 & 75.5781 \\
\hline Nov-06 & 65.33 & 61.84590667 & 3.480247 & 5.327494 \\
\hline
\end{tabular}


Texas Tech University, Nitin Shenoy, May 2011

\begin{tabular}{|c|c|r|r|r|}
\hline Dec-06 & 98.94 & 116.8898658 & -17.9537 & -18.1468 \\
\hline Jan-07 & 125.28 & 113.6313574 & 11.65018 & 9.2992 \\
\hline Feb-07 & 127.00 & 129.95294 & -2.94986 & -2.32267 \\
\hline Mar-07 & 52.45 & 104.6534697 & -52.2042 & -99.5329 \\
\hline Oct-07 & 25.33 & 45.60079097 & -20.2669 & -79.9995 \\
\hline Nov-07 & 49.95 & 2.208333333 & 47.74551 & 95.57925 \\
\hline Dec-07 & 87.79 & 54.35272774 & 33.43496 & 38.08616 \\
\hline Jan-08 & 113.71 & 126.4733961 & -12.7665 & -11.2275 \\
\hline Feb-08 & 93.97 & 177.69318 & -83.7209 & -89.091 \\
\hline Mar-08 & 74.47 & 117.3149806 & -42.8473 & -57.5381 \\
\hline Oct-08 & 21.94 & 59.57873161 & -37.6372 & -171.534 \\
\hline Nov-08 & 32.65 & -0.10688 & 32.75303 & 100.3274 \\
\hline Dec-08 & 92.29 & 60.97695613 & 31.31227 & 33.92842 \\
\hline
\end{tabular}

3) Forecasting Performance Chart for Mobile Homes (Dec-Oct)

\begin{tabular}{|c|c|r|r|l|}
\hline $\begin{array}{c}\text { Month- } \\
\text { Year }\end{array}$ & $\begin{array}{l}\text { Actual Demand } \\
\left(\mathrm{A}_{\mathrm{T}}\right) \text { (gallons/month) }\end{array}$ & $\begin{array}{l}\text { Forecasted } \\
\text { Demand }\left(\mathrm{F}_{\mathrm{T}}\right)\end{array}$ & Error $\left(\mathrm{E}_{\mathrm{T}}\right)$ & $\begin{array}{l}\% \mathrm{E} \text { (in } \\
\%)\end{array}$ \\
\hline Dec-04 & 57.61 & 76.05745161 & -18.4441 & -32.0136 \\
\hline Jan-05 & 83.13 & 72.56196774 & 10.5647 & 12.70916 \\
\hline Feb-05 & 85.39 & 64.8185 & 20.56817 & 24.08827 \\
\hline Mar-05 & 46.00 & 51.49196774 & -5.49197 & -11.9391 \\
\hline Oct-05 & 15.73 & 25.95551613 & -10.2255 & -65.0065 \\
\hline Nov-05 & 58.99 & 47.41066667 & 11.576 & 19.62477 \\
\hline Dec-05 & 75.83 & 78.29067742 & -2.46401 & -3.24953 \\
\hline Jan-06 & 69.57 & 93.72906452 & -24.1624 & -34.7327 \\
\hline Feb-06 & 91.35 & 72.1285 & 19.21817 & 21.03872 \\
\hline Mar-06 & 23.92 & 36.15067742 & -12.2307 & -51.1316 \\
\hline Oct-06 & 39.41 & 22.36293548 & 17.04373 & 43.25088 \\
\hline Nov-06 & 49.51 & 49.51766667 & -0.00433 & -0.00875 \\
\hline Dec-06 & 65.13 & 75.08648387 & -9.95482 & -15.2841 \\
\hline Jan-07 & 79.91 & 76.05745161 & 3.849215 & 4.817139 \\
\hline Feb-07 & 71.03 & 79.4385 & -8.40517 & -11.8327 \\
\hline Mar-07 & 20.70 & 59.35680645 & -38.6568 & -186.748 \\
\hline Oct-07 & 9.75 & 42.07358065 & -32.3236 & -331.524 \\
\hline Nov-07 & 57.62 & 26.54133333 & 31.07867 & 53.93729 \\
\hline Dec-07 & 65.13 & 46.15164516 & 18.98169 & 29.14282 \\
\hline
\end{tabular}


Texas Tech University, Nitin Shenoy, May 2011

\begin{tabular}{|c|r|r|r|r|}
\hline Jan-08 & 82.29 & 78.29067742 & 4.002656 & 4.863888 \\
\hline Feb-08 & 62.06 & 102.8735 & -40.8135 & -65.7646 \\
\hline Mar-08 & 59.61 & 65.9593871 & -6.34605 & -10.6454 \\
\hline Oct-08 & 22.13 & 45.47196774 & -23.3386 & -105.446 \\
\hline Nov-08 & 34.17 & 22.829 & 11.34433 & 33.19645 \\
\hline Dec-08 & 100.17 & 48.19067742 & 51.98266 & 51.89271 \\
\hline
\end{tabular}

